Source Term Determination for P-Area Reactor Groundwater Operable Unit

March 25, 2003

Westinghouse Savannah River Company

Savannah River Site

Aiken, SC 29808

Prepared for the United States Department of Energy under Contract No. DE-AC09-96-SR18500 
This document was prepared in conjunction with work accomplished under Contract No. DE-AC09-96SR18500 with the U. S. Department of Energy.

\section{DISCLAIMER}

This report was prepared as an account of work sponsored by an agency of the United States Government. Neither the United States Government nor any agency thereof, nor any of their employees, makes any warranty, express or implied, or assumes any legal liability or responsibility for the accuracy, completeness, or usefulness of any information, apparatus, product or process disclosed, or represents that its use would not infringe privately owned rights. Reference herein to any specific commercial product, process or service by trade name, trademark, manufacturer, or otherwise does not necessarily constitute or imply its endorsement, recommendation, or favoring by the United States Government or any agency thereof. The views and opinions of authors expressed herein do not necessarily state or reflect those of the United States Government or any agency thereof.

This report has been reproduced directly from the best available copy.

Available for sale to the public, in paper, from: U.S. Department of Commerce, National Technical Information Service, 5285 Port Royal Road, Springfield, VA 22161, phone: (800) 553-6847, fax: (703) 605-6900

email: orders@ntis.fedworld.gov

online ordering: http://www.ntis.gov/help/index.asp

Available electronically at http://www.osti.gov/bridge

Available for a processing fee to U.S. Department of Energy and its contractors, in paper, from: U.S. Department of Energy, Office of Scientific and Technical Information, P.O. Box 62, Oak Ridge, TN 37831-0062,

phone: (865)576-8401,

fax: (865)576-5728

email: $\underline{\text { reports@ adonis.osti.gov }}$ 


\title{
Source Term Determination for P-Area Reactor Groundwater Operable Unit
}

\author{
Margaret R. Millings \\ Karen M. Vangelas \\ Mary K. Harris
}

U.S. Department of Energy

Westinghouse Savannah River Company

Savannah River Site

Aiken, SC 29808

Operated by:

Westinghouse Savannah River Company

For the U.S. Department of Energy under Contract No. DE-AC09-96-SR18500 


\section{Table of Contents}

Page No.

$\begin{array}{lr}\text { Executive Summary } & 1 \\ \text { Introduction } & 1 \\ \text { Early Foundation Grouting Reports } & 2 \\ \text { Reactor Power Capacity } & 3 \\ \text { Potential Sources of Organics } & 4 \\ \text { Potential Sources of Radioactive Liquid Discharges } & 4 \\ \quad \text { Disassembly Basin Purges } & 4 \\ \quad \text { Cooling Water } & 6 \\ \quad \text { Miscellaneous Releases } & 7 \\ \text { Discharge Points of Radioactive Releases } & 9 \\ \quad \text { Steel Creek } & 9 \\ \text { Summary of Findings } & 12 \\ \text { References } & 14 \\ \quad \quad & 15\end{array}$

Tables

Table 1 Subsurface Characterization and Foundation Grouting Information $\quad 17$

Table 2 Timeline and History for P Reactor 20

Table 3 Common Radiological Contaminants 21

\section{Figures}

Figure 1 Location of Grouted Boreholes in P Area from Corps of Engineers 17

Foundation Grouting Operations

Figure 2 Power (thermal) Output for P, R, and L Reactors 18

Figure 3 Map of P Reactor Facilities 19

Figure 4 Discharge to Steel Creek (DPSPF-6580-8) 3/4/1960 22

Figure 5 Effluent Stream, P Area Construction of Discharge Point to Par Pond 22 (DPSPF-6782-47) 8/17/1960

Figure 6 Effluent Stream, P-Area Construction of P Area Canal to Par Pond 23

(further downstream from $\mathrm{P}$ Area, heading toward Par Pond (DPSPF-68972-36) 8/17/1960

Figure 7 Effluent Canal, P-Area Discharge Point to Par Pond Completed 23 (DPSPF-7459-1) 5/5/1961

Figure 8 Effluent Canal, P Area Completion of P Area Canal to Par Pond 24 (further downstream from P Area, heading toward Par Pond) (DPSPF-7459-5) 5/5/1961

Figure 9 Effluent Canal, P-Area Looking downstream toward Par Pond 
(DPSPF-7459-2) 5/5/1961

Figure $10 \mathrm{P}$ and L Reactor Releases to Streams (Steel Creek), Tritium Activity 25 Originally Released

Figure 11 Tritium Released to Stream (Steel Creek) 25

Figure 121985 Gamma Overflight Data $\quad 26$

Figure 131991 Gamma Overflight Data 27

Figure $14{ }^{137}$ Cs Released to Stream (Steel Creek) 28

Figure $15{ }^{90} \mathrm{Sr}$ Released to Stream (Steel Creek) 28

Figure 16 Annual Tritium Activity Released to Steel Creek and to Seepage Basins 29

Figure 17 Annual Effluent Volumes Released to Steel Creek and to Seepage Basins 29

Figure 18 Tritium in Seepage Basins and PSB Wells 30

Figure 19 Tritium in Seepage Basins and PSB Wells 1978-1999 30

Figure $20{ }^{137} \mathrm{Cs}$ Released to Seepage Basins $\quad 31$

Figure $21{ }^{90} \mathrm{Sr}$ Released to Seepage Basins $\quad 31$

\section{Appendices}

Appendix A. Documents Reviewed (from Unclassified and Classified Searches) 32

Appendix B. Examples of Events in P Area Disassembly Basin History 37

Appendix C. Examples of Documented Leaks and Spills for P Reactor 40

Appendix D. Mass Balance Calculations of ${ }^{137} \mathrm{Cs}$ in P Reactor Seepage Basins 44 


\section{Executive Summary}

A review of historical documents has been conducted to identify potential sources of contamination to the P Area Reactor Groundwater Operable Unit. Both classified and unclassified documents repositories at the Savannah River Site were searched. The results of the historical document review indicated the principal sources of groundwater contamination are associated with routine operating practices over the operating life of the P Reactor facilities. The document search did not find any major abnormal release events/accidents that would have caused a substantial release to the ground surface or surface water bodies. Steel Creek and the Reactor Seepage Basins were the primary discharge points of radioactive contamination. Based on normal operations of land disposal, organic solvent sources would include the ground surface adjacent to maintenance shops in the reactor facility. More specifically, the ground outside of the 704-P maintenance shop, which was a large user of organic solvents, would likely serve as a potential organic solvent source. Review of geologic investigations prior to construction of the reactor, indicate zones of potential preferential flow in the Lower Aquifer Zone of the Upper Three Runs Aquifer. Contaminated water intersecting these zones would potentially be transported at a faster rate than the surrounding formation.

Tritium, cesium-137 $\left({ }^{137} \mathrm{Cs}\right)$ and strontium-90 $\left({ }^{90} \mathrm{Sr}\right)$ were identified as the most probable radionuclides to contaminate the groundwater. The sources of these contaminants are no longer receiving additional loadings. Thus, the sources are depleting. Of these three radionuclides, tritium is the most mobile in the groundwater. Review of existing data, indicate that ${ }^{137} \mathrm{Cs}$ and ${ }^{90} \mathrm{Sr}$ are bound in the shallow sediments of both the P-Reactor Seepage Basins and Steel Creek.

The review indicates the major sources of groundwater contamination are the results of routine operations during reactor operations and that there may be geologic features of importance in transport of groundwater contaminants.

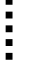

\section{Introduction}

The Soils and Groundwater Closure Projects Reactor Team requested support from the Environmental Sciences and Technology Department of the Savannah River Technology Center to conduct a source term determination for the P Area Reactor Groundwater Operable Unit. This source term evaluation involved searching the document database to identify and review documents that might provide information on routine discharges, leaks, spills, emergency discharges and any other releases to the environment associated with the reactor facility. Atmospheric releases were not part of this evaluation. The identified documents reviewed and pertinent findings are recorded in this report. 
More specifically, this source term evaluation consisted of identifying documents through unclassified and classified searches in addition to reviewing known historical documents. Searches were conducted by using the keyword "P Area" together with other keywords such as "Radionuclide", "Reactor", "Spill”, "Leak", "Releases", "Incidents", "Seepage Basins", "Disassembly Basin", "Moderator", "TCE", "PCE”, "Strontium”, "Heat Exchanger", "Distillation Column”, "Process Sewers", "Unusual Incident”, "Reactor Construction", "Reactor Foundation", "Soft Zone or Soft Spot", "Calcareous Material", "Subsidence", "Sinks or Depressions or Excavations", or "Reactor Grouting or Surface Grouting". Appendix A provides the documents found and reviewed resulting from the unclassified and classified searches. Types of data reviewed also included weekly and monthly control and environmental monitoring reports, reactor memorandums and reports, material balance reports and existing technical reports and books. A phone interview was also conducted with Greg Burbage who has worked in environmental compliance at SRS and is familiar with the history, operations, and environmental issues associated with the reactors. Results from the document search and phone interview include findings concerning foundation grouting, power capacity, liquid discharge sources, and points of discharge. However, there were no findings of major spills, leaks, or other unusual or previously unreported releases. Moreover, specific information on the disposal of organic solvents was not found for P-Area operations.

\section{Early Foundation Grouting Reports}

In July 1950 surveying began for the operating facilities at SRS. The Atomic Energy Commission authorized the Corps of Engineers to conduct preliminary soils investigations in connection with the foundation design of SRS structures (i.e., reactors, separations facilities, etc.) in January 1951. The purpose was: (a) to establish the general geology of the area to permit correlation and interpretation of the boring data, geophysical investigations, and laboratory test results; (b) to ascertain the engineering significance of hundreds of undrained surface depressions or "sinks" found in the area; and (c) to furnish background information for investigation of the ground water and associated surface and subsurface drainage problems (1).

The results of the foundation grouting operations, conducted by the Corps of Engineers as part of the preliminary soils investigations, indicated that there were significant amounts of grout lost to the subsurface near the reactor facilities. The "soft" zones were determined to have developed from the "solution of calcareous and possibly other material at depth". Evaluation of the boreholes at P Area reveals that the average top depth of the calcareous zone was approximately $175 \mathrm{ft}$ below land surface and the average thickness varied from approximately 10 to $40 \mathrm{ft}$. The actual thickness of this zone may be greater, due to pronounced variability and the replacement of the dissolved calcareous sediments by other minerals (2). The depths reported for P Area indicate that this "soft" zone or calcareous zone is predominantly present in the Lower Aquifer Zone (LAZ) of the Upper Three Runs Aquifer. 
Because the emphasis of the work was structural stability of the constructed facilities, the subsurface investigations were conducted in the immediate vicinity of the planned locations of the reactor buildings. The drilling pattern was a grid system of holes at the corners of a $50 \mathrm{ft}$ by $50 \mathrm{ft}$ square with an extra hole in the center. The drilling pattern extended $30 \mathrm{ft}$ or more beyond the perimeter of the reactor buildings.

Borings were grouted if abnormalities were encountered when drilling the borehole. Abnormalities included the sudden dropping of the drill rods and sudden or excessive loss of water and drilling mud. During the grouting process, grout was seen venting from previously drilled borings in the general vicinity. The horizontal distance between the hole in which grout was injected and from which it vented varied from 40 to $235 \mathrm{ft}$. Some of the venting boreholes had not shown any abnormal behavior during drilling operations and thus were not originally grouted. This venting of nearby holes indicated the presence of preferential channels in the subsurface. Flow of a viscous material such as grout would indicate water should readily flow through these zones. The failure to find thick layers of grout at any one location, even where large quantities were pumped into the foundation, suggested to the investigators that large cavities did not exist. Instead, the investigators concluded that a porous or "spongy" condition existed with the soil containing numerous solution channels that were sufficiently large to receive the sand-cement grout (2). Figure 1 shows the locations of the grouted holes in relation to $\mathrm{P}$ Reactor and provides the approximate volume (cubic feet) of grout used in the each hole. Table 1 provides information regarding the total number of holes drilled, the number of holes grouted and the quantity of grout used in P Area and for comparison, a nearby reactor area, L Area.

\section{Reactor Power Capacity}

P Reactor, the second reactor completed at the SRS, went critical February 20, 1954 and operated with relatively few interruptions until 1988. Similar to the other SRS reactors, P Reactor produced primarily tritium and plutonium and was initially designed to operate at low temperatures (less than $100^{\circ} \mathrm{C}$ ) and pressure (slightly above atmospheric pressure) using heavy water (deuterium or $\mathrm{D}_{2} \mathrm{O}$ ) to moderate and cool the reactor (3).

In the mid-1950's increased defense needs required greater production from the reactors. With improvements in fuel and target elements, heat exchangers systems, and flow distribution systems, reactor power gradually increased from 378 megawatts to 2,250 megawatts by the end of 1957. The completion of Par Pond in 1958 and the addition of pumps at Par Pond in 1960 allowed further increases in reactor power by providing more cooling water for the reactors $(3,4)$. Figure 2 shows the thermal or power output for $P$ Reactor, with the nearby $\mathrm{R}$ and L Reactors for comparison (5). P Reactor reached its maximum monthly power output of 73,600 megawatt days in December 1963 (daily average of 2,374 megawatts) (5). It operated fairly continuously for nearly 35 years and maintained relatively high power levels for much of that time. Although R and L Reactors reached similar peaks in power, they had much shorter operational histories. 
Thermal output from the reactors can be used as a measure of reactor production (generation of fission products) and therefore can provide insight regarding effluents released into the environment. More specifically, P Reactor's long operational history corresponds with a long history of discharges, which included disassembly basin purges, reactor cooling water, and miscellaneous spills and leaks related to normal operations. The duration of P Reactor's operation may have a particularly large impact on the nature and distribution of contaminants found.

\section{Potential Sources of Organics}

Solvents and diesel fuel used in P Reactor operations were disposed of onsite. In particular, the 704 maintenance shop and maintenance shops within the 105 reactor building used solvents for cooling and cleaning equipment. The 704 shop performed maintenance on the heavy industrial equipment used in the power house and was probably the largest user of solvents (6). No written records were found on solvent usage. However, verbal history indicates that the standard practice during early operations of reactor facilities was land disposal of small quantities of solvent within the reactor facility perimeter fence. More specifically, a drum was used to collect the solvent waste and when full the solvent was discarded onto the ground 50 to 100 yards from the building (6). Figure 3 shows the location of the 704 maintenance shop in relation to other P Reactor facilities.

\section{Potential Sources of Radioactive Liquid Discharges}

Through parts of its operational history, P Reactor released liquid effluent to Steel Creek, Par Pond, and the Reactor Seepage Basins (i.e. three inter-connected seepage basins). Liquid effluents included disassembly basin purges, cooling water from the reactor heat exchangers, and other miscellaneous sources. Table 2 provides a timeline showing the history and predominant destination of disassembly basin purges and releases of cooling water and process sewer water.

\section{Disassembly Basin Purges}

The P Reactor disassembly basin consists of a 4.6 million gallon basin constructed of epoxy-lined or painted, reinforced concrete. According to a 1995 DOE technical report, the reactor disassembly basins were all designed to withstand a 1000 psf (pounds per square foot) blast load and a minor 0.1 earthquake, however leakage through basin walls and water stops could occur even under normal conditions. The report cites as an example the L Reactor disassembly basin where the concrete wall next to the reactor building reportedly had cracks that leaked. In addition, the report noted that the disassembly basins did not have systems designed to detect small leaks in the basin walls or water stops (7). No evidence was found in this document search that the P Reactor 
disassembly basin had known or documented leaks in the basin concrete walls or water stops.

P Reactor's disassembly basin includes four sections (vertical tube storage section or VTS, the machine area, the horizontal bundle and bucket storage area or HBBS, and the transfer area) used for disassembling and storing irradiated fuel and target elements (7). The basins were initially designed so that the water was free circulating among the four sections (i.e. water used in one section mixed with water used in other sections) $(6,8)$. When irradiated elements were first discharged from the reactor they were suspended underwater from stainless steel hangers on a monorail system in the vertical tube storage (VTS) section. This cooling period in the VTS allowed short-lived radionuclides to decay so that the elements could be disassembled and eventually transferred to the separations area for reprocessing. Initially, VTS water was purged continuously (several thousands gallons per minute) to site streams. A continuous feed of "fresh" water was used to cool the stored fuel and targets and to maintain the clarity of the water $(8,9)$.

As production increased in the late 1950's, controls began to be emplaced to reduce the amount of radioactivity released to streams. The volume of continuous flow through the VTS was reduced and some of the disassembly basin overflow weirs were closed. In 1963 the VTS section was isolated from the rest of the disassembly basin in all of the reactor areas. The isolated VTS water was recirculated to allow for radionuclide decay before it was released and mixed with other disassembly basin water. Portable filter/deionizer systems and heat exchanger systems were also installed. These provisions helped to decrease the volume and radioactivity of purge water released from the basin $(8,9)$. In the late 1960's and early 1970's, all of the disassembly basin overflow weirs were closed and permanent sand filters were installed to help maintain clarity of the water. It is estimated that less than $1 \%$ of the total aqueous releases of ${ }^{32} \mathrm{P},{ }^{51} \mathrm{Cr},{ }^{60} \mathrm{Co}$, ${ }^{65} \mathrm{Zn}$, and ${ }^{90} \mathrm{Sr}$ for P Reactor occurred after 1970; the greatest amounts of these constituents were released in the 1960's $(8,9,10)$.

Even with instituted controls, periodic purging of the disassembly basin occurred primarily to reduce the tritium and other radioactive exposure to personnel. The frequency of disassembly basin purging is not clear. The P-Reactor 1993 Annual Groundwater Monitoring Report states that the disassembly basin was purged biannually although elsewhere in the document it specifies that the basin was purged when tritium concentrations reached 400,000 $\mathrm{pCi} / \mathrm{mL}$ (11). Disassembly basin purge water was released predominately to Steel Creek from 1954 to 1956, 1969, and from 1971 to 1977; it was released mainly to the seepage basins from 1957 to 1968,1970 , and from 1978 to $1991(8,9)$ (table 2). Standard practice for releasing disassembly basin purges to streams involved mixing the purge water with large volumes of cooling water from the heat exchangers to help dilute and reduce the concentration of the releases (8). However, in the 1970's, most of the cooling water was no longer discharged to Steel Creek. This resulted in minimal dilution of the disassembly basin water prior to discharge into Steel Creek (12). 
During normal reactor operations, contaminants entered the disassembly basin water through moderator adsorbed to the surfaces of irradiated fuel and target elements discharged to the basin and through small cracks or defects in the cladding of discharged irradiated elements. These contaminants included tritium (which ranged from 0 to 17 $\mathrm{Ci} / \mathrm{L}$ in the reactor moderator), activation products (e.g. ${ }^{32} \mathrm{P},{ }^{51} \mathrm{Cr},{ }^{60} \mathrm{Co}$, and ${ }^{65} \mathrm{Zn}$ ), and fission products (e.g. ${ }^{90} \mathrm{Sr},{ }^{137} \mathrm{Cs}$, and $\left.{ }^{129} \mathrm{I}\right)(8,9,13)$. Weekly and monthly environmental and health monitoring reports of reactor operations began in the early 1960's to document specific contaminant activities in the disassembly basin water and weir releases. Based on the reports, tritium would have contributed the most activity from the disassembly basins. Table 3 lists common radiological contaminants with a description of how they were generated and their associated half-life. Based on the extremely short half-life of ${ }^{32} \mathrm{P}$ and ${ }^{51} \mathrm{Cr}$, these activation products would have been completely decayed prior to discharge or shortly thereafter. The other activation products with half-lives in the hundreds of days to a few years would have been found in trace amounts compared to the fission products. The history of releases and impact of the activation products are documented in other reports $(9,14)$.

Appendix B presents a descriptive history of the disassembly basin and discharged elements (normal and failed). A "failed" element is described as a rod in which small defects in element cladding developed into holes or splits. A failed element had the potential to release considerable concentrations of radionuclides to the moderator and disassembly basin water $(9,13)$. To minimize the release of radionuclides, the reactor was typically shut down and the failed element was transferred to a "harp", a container stored underwater in the disassembly basin and vented to the reactor stack, to cool. Prior to identification of the failure, the failed rod would release higher levels of radionuclides to the disassembly basin than a normal rod. As the P-Reactor 1993 Annual Groundwater Monitoring Report indicated the disassembly basin was purged either biannually or when concentrations reached $400,000 \mathrm{pCi} / \mathrm{mL}(11)$, it can be assumed that increased numbers of discharged rods (particularly failed rods) would correlate to increased purges of the disassembly basin to the discharge point.

\section{Cooling Water}

In addition to disassembly basin purge water, large quantities of reactor cooling water were released from $\mathrm{P}$ Reactor. Cooling water consisted of river or pond water which circulated around the outside (or shell side) of the reactor heat exchanger tubes to remove heat from the moderator which circulated inside the tubes. Although cooling water consisted predominantly of river or pond water, it also contained moderator that had escaped through leaks and cracks in the heat exchanger system. This moderator had the potential to contain tritium (from 0 to $17 \mathrm{Ci} / \mathrm{L}$ ) and minor amounts of activation products and fission products that had collected during normal operations. Release of contaminants to the environment through leakage to the cooling water is considered a minor pathway compared to the radionuclides released from the disassembly basin $(8,9)$. P Reactor cooling water was discharged to Steel Creek until the early 1960's when the canal to Par Pond was completed (table 2). Figures 4 through 9 show the outfall to Steel 
WSRC-TR-2003-00142

March 25, 2003

Page 7 of 49

Creek and the construction and completion of the outfall and canal to Par Pond. Between 1961 and 1963 cooling water from P Area, which was comprised of Par Pond water (containing R Area releases) and make up water from the river, was released to both Par Pond and Steel Creek. After 1963, most of P Reactor's cooling water was discharged to Par Pond (12,15). Later, after the construction of L-Lake in 1985, all of the cooling water was discharged to Par Pond $(8,9)$. This document search produced little analytical data concerning cooling water discharges.

\section{Miscellaneous Releases}

Other miscellaneous releases included water in the reactor process sewer system, leaks that developed during $\mathrm{P}$ Reactor operations and spills that occurred during maintenance periods. The reactor process sewer system primarily received cooling water from the shell side of the disassembly basin heat exchangers but also included other process water (e.g. from numerous floor, roof, and fan drains). Like the cooling water, the process sewer system water was released to Steel Creek until the early 1960's when most of it was diverted to Par Pond. With the construction of L-Lake, the process sewer system water was all diverted to Par Pond $(8,9)$.

Appendix $\mathrm{C}$ shows some examples of documented leaks and spills for P Reactor cited in weekly and monthly environmental and health monitoring reports, material balance reports, and reactor reports. Some of the wastewater from leaks and spills was collected in process sumps and analyzed for radionuclides and moderator content. Disposal of this wastewater included processing through the D-Area Heavy Water Rework Facility or through the waste evaporators at the separations areas, or discharging to seepage basins or streams depending on the analytical results (9). For many of the leaks listed in Appendix C, the method of disposal for the collected wastewater is unclear (or not documented).

Since the moderator in P Area had the potential to contain considerable amounts of tritium during parts of its operational history (up to approximately $15 \mathrm{Ci} / \mathrm{L}$ ), a loss of moderator due to leaks, spills, or routine maintenance could release significant amounts of tritium to the environment (16). However, since moderator was generally considered a valuable commodity, efforts were made to recover lost moderator. A report from 1984 cited that $800 \mathrm{lbs}$ of lost moderator had an estimated value of $\$ 60,000$ (or $\$ 75$ per pound) (Appendix C). Monthly material balance reports tracked the shipments, use, storage, loss and recovery of moderator for all of the reactors. These losses were categorized under headings such as "normal operational losses", "material unaccounted for", "inventory differences", and "accidental losses". Losses from discharges and shutdowns, heat exchanger leaks and maintenance, and maintenance/replacement work on the evaporators and deionizers were often included under "normal operational losses". Stack losses appear to have been considered "material unaccounted for" in the early material balance reports whereas later it was included under "normal operational losses". 
A review of the K Area Reactor Facility conducted in 1999 identified the distillation columns and heat exchanger laydown area as possible sources of contamination (16). The distillation columns, which were located outside of the 105-P reactor building, processed tritiated moderator (heavy water) for purification purposes. Moderator may have been released from the distillation columns due to small leaks or during routine maintenance. For example, a 1971 report documented a loss of approximately $150 \mathrm{lbs}$ of moderator during a general overhaul maintenance of the distillation facility at $\mathrm{P}$ Area. Another incident in 1983 involved a broken line at the distillation pad due to freezing, which released moderator containing an estimated $85 \mathrm{Ci}$ of tritium to Steel Creek via the storm sewer (Appendix C). The heat exchanger laydown area consisted of old heat exchangers that had been replaced and temporarily stored in a laydown area within the reactor facilities. These parts may have contained residual moderator with tritium on their surfaces and served as potential sources of tritium to the environment. No specific documentation concerning the P Area heat exchanger laydown area was found in this search.

In 1963 a 50 million gallon earthen retention basin was constructed as part of the Emergency Cooling System (ECS) (figure 3). This basin was designed to hold contaminated water that would be released if a loss of cooling or loss of circulation accident occurred within the reactor (11). No record of such a release was found. The retention basin was also used as in the case of $\mathrm{K}$ Reactor if the seepage basins were ineffective at percolating. Verbal communications with a worker knowledgeable about $\mathrm{P}$ Reactor indicates that the P Area retention basin was never used for this purpose (6). In 1979, a 500,000 gallon storage tank was added to the basin to store contaminated water as a backup for the process water storage tank. According to the P-Reactor 1993 Annual Groundwater Monitoring Report, the system was set up for moderator or water leaks that would collect in the $-40 \mathrm{ft}$ sumps. The first 60,000 gallons of moderator or water would be pumped to Building 106, the process water storage tank, and then the next 500,000 gallons would be pumped to the new storage tank in the retention basin (figure 3). Any additional moderator or water would be routed to the retention basin. Any moderator or water leakage originating in the reactor room $0 \mathrm{ft}$ level or from pump operation was supposed to go to the retention basin as well (11). Based on this document search, it is unclear if or to what extent this system was used. According to the "RI Work Plan for the Steel Creek Integrator Operable Unit (U)", the ECS (emergency cooling system) was never activated and the P Area retention basin never received any discharges (17). 


\section{Discharge Points of Radioactive Releases}

\section{Steel Creek}

Figure 10 shows the annual curies of tritium originally released to Steel Creek from L and P Reactors. The data comes from the report "Radioactive Releases at the Savannah River Site 1954-1989 (U)", which provides a summary and history of effluent releases for various facilities at the SRS (14). The report includes liquid and air monitoring results from routine and special sampling events but does not contain data related to spills or leaks. As shown by figure 10, P Reactor's annual contribution to the curies of tritium in Steel Creek was not exceedingly different than L Reactor's. However, the duration that P Reactor discharged is much longer, resulting in a larger loading to Steel Creek.

Flow rates in Steel Creek have varied widely according to the operational history of the reactors and have affected the concentrations of radionuclides discharged to Steel Creek. In the early 1960's when P and L Reactors were both discharging to Steel Creek, flow in Steel Creek was approximately $600-800 \mathrm{ft}^{3} / \mathrm{sec}$. After P Reactor's cooling water was diverted to Par Pond, flow rates decreased to $400 \mathrm{ft}^{3} / \mathrm{sec}$ in the late 1960 's. With the shutdown of L Reactor in 1968, flow rates decreased further to around 20-30 $\mathrm{ft}^{3} / \mathrm{sec}$ and remained at this rate until all of $P$ Reactor's process effluents were diverted to Par Pond in the mid-1980's. This decrease in flow rate in Steel Creek in the late 1960's and 1970's resulted in less water available for dilution contributing to the rise in tritium and other radionuclide concentrations in the creek $(8,12,17)$.

Figure 11 shows the curies of tritium originally released to Steel Creek from P Reactor with calculated decay corrected annual and cumulative activities. The increase in the annual tritium activity released to Steel Creek appears to correspond with the rise in reactor power from 1955 through the mid 1960's. In the early and mid 1970's while the seepage basins were deactivated, Steel Creek received disassembly basin purge water. Instituted controls (e.g. sand filters/deionizers) on the disassembly basin water would have had little affect on tritium concentrations. Consequently disassembly basin purges would have added to the tritium released to Steel Creek during this time. With the reactivation of the seepage basins in 1978 the tritium released to the creek dropped considerably. After all miscellaneous effluents and cooling water discharges were diverted from Steel Creek in 1985 and P Reactor was shutdown in 1991, no major sources existed.

Since ${ }^{137} \mathrm{Cs}$ is one of the longer-lived radionuclides (with a half life of 30.1 years) discharged during reactor operations and its movement through surface water and groundwater can be retarded by sorption, its release history to Steel Creek is presented here. Out of the estimated $600 \mathrm{Ci}$ of ${ }^{137} \mathrm{Cs}$ released from the reactors to site streams, only about one-third is thought to have reached the Savannah River; the other two-thirds is thought to remain in streams beds, ponds, and wetlands onsite (13). In general Cs tends to be bound strongly to clays exchanging for cations between the structural layers of clay minerals. For Cs, this process occurs relatively quickly whereas its release is very slow 
(the process is sometimes thought of as irreversible). Adsorption to iron oxides and humic material can also affect the migration of Cs but typically to a lesser extent. The high retardation potential of Cs coupled with the variability of discharges and erosional/depositional episodes associated with the Steel Creek would likely have made its distribution partly scattered in surficial sediments along Steel Creek. It also had the potential to travel farther downstream, for example bound to clay particulates that were carried with the flow of discharge water. Figures 12 and 13 present gamma overflight data from 1985 and 1991 for P Reactor and Steel Creek. These figures show that part of ${ }^{137}$ Cs released from $P$ Reactor has remained bound probably to surficial sediments along Steel Creek. In addition, the similarity of the data from the two overflights demonstrate that the distribution of ${ }^{137} \mathrm{Cs}$ that was deposited along Steel Creek has changed little from 1985 to 1991 also suggesting that the ${ }^{137} \mathrm{Cs}$ is bound strongly to sediment along the creek.

As figure 14 shows, most of the ${ }^{137}$ Cs released to Steel Creek occurred during the 1960 's. Again, this increase took place during the rise in reactor power. More specifically, during this time monitoring of reactor discharges revealed that fuel element failures were a large contributor to the radioactive releases (more than the number and type of fuel discharges) and the "severity of certain failures" made the prediction of radioactive releases uncertain (18). In a 1963 monthly operating report, a P Area failed element discharge was documented as an example of the large impact that one failed element can have on annual releases: a failed Mark VB element discharged in 1962 accounted for $60 \%$ of the long-lived radionuclides $(64 \mathrm{Ci})$ and $50 \%$ of the short-lived radionuclides (178 Ci) for the year (18). During the 1960's, disassembly basin purges were discharged primarily to the seepage basins, however failed elements also had the potential to release radionuclides into the moderator $\left(\mathrm{D}_{2} \mathrm{O}\right)$, which could be discharged with cooling water or miscellaneous effluents to Steel Creek.

In addition, another source of ${ }^{137}$ Cs was noted in a March 1970 monitoring report as contributing to the Cs released to the Savannah River. In 1964 partially declad irradiated fuel elements were transferred from R Reactor disassembly basin to P Reactor disassembly basin. The fuel was stored in $15 \mathrm{ft}$ cans that allowed for direct venting to the process room exhaust filters. Transfer of these elements from the P Area disassembly basin to the Receiving Basin for off-site fuel (RBOF) did not start until September 1968 at which point the ${ }^{134,137} \mathrm{Cs}$ activity released to the river decreased from $42 \mathrm{Ci}$ to $13 \mathrm{Ci}$ in 1969. The final transfer of elements to the RBOF took place in January 1970 (19).

Like ${ }^{137} \mathrm{Cs},{ }^{90} \mathrm{Sr}$ is another one of the longer lived radionuclides (with a half life of 28.8 years) released during reactor operations. ${ }^{90} \mathrm{Sr}$ was also a fission product produced from the neutron induced fission reactions in the reactors and would have been released in similar pathways as the ${ }^{137} \mathrm{Cs}$ (e.g. moderator contamination from irradiated elements and failed elements). Figure 15 provides the release history of ${ }^{90} \mathrm{Sr}$ to Steel Creek and like ${ }^{137} \mathrm{Cs}$ it was predominantly released during the 1960 's. It is estimated that $90 \%$ of the ${ }^{90} \mathrm{Sr}$ which entered site streams was carried rapidly to the Savannah River; the other $10 \%$ is thought to have been deposited in stream beds, floodplains, or ponds (10). The migration of the deposited Sr would have been affected by adsorption to clay minerals, metal oxides and organic matter. However, relative to $\mathrm{Cs}$, Sr tends to sorb and desorb 
easily and competes with calcium for exchange sites. Therefore, it generally tends to migrate faster than the Cs.

Although much of the radionuclides released from the P Reactor appears to be attributed to irradiated elements and fuel element failures, other smaller releases of radionuclides to Steel Creek occurred during regular operations. For example, a small contributor to the release of ${ }^{90} \mathrm{Sr}$ and ${ }^{137} \mathrm{Cs}$ to Steel Creek early in P Reactor operations was through cooling water from Par Pond. Beginning in 1958, P Reactor received some of its cooling water from Par Pond, which contained radionuclides from R Area releases. Analyses of cooling water received from Par Pond indicated that approximately $6.6 \mathrm{Ci}$ of ${ }^{89,90} \mathrm{Sr}$ (and 19.8 Ci of ${ }^{134,137} \mathrm{Cs}$ ) released to Steel Creek between 1960 and 1963 were from cooling water originating from Par Pond. This cooling water was discharged solely to Steel Creek until May 1961 when the P Area canal to Par Pond was completed and some of the cooling water was diverted to Par Pond. By 1963 most of the P Reactor's cooling water was discharged to Par Pond (15). Another small source of ${ }^{137} \mathrm{Cs}$ to Steel Creek was cited in a monthly monitoring report in October 1972. During the drainage of the 186-3P cooling water settling basin approximately 0.05 Curies of ${ }^{137} \mathrm{Cs}$ were released in sludge and effluent to Steel Creek (20). Since other documents concerning the drainage of cooling water settling basins were not found in this search, it is unclear how frequently the cooling water settling basins were drained.

The annual activity associated with tritium, ${ }^{137} \mathrm{Cs}$ and ${ }^{90} \mathrm{Sr}$ as reported in "Radioactive Releases at the Savannah River Site 1954-1989 (U)" were decay corrected and a decay corrected cumulative activity was calculated. These are shown on Figures, 11, 14, and 15, respectively. As there are no new discharges to Steel Creek from P-Reactor, these figures show a depleting source of all three radionuclides. Based on the highest cumulative activity level, the activities have decreased by approximately $70 \%, 50 \%$ and $50 \%$ for tritium, ${ }^{137} \mathrm{Cs}$ and ${ }^{90} \mathrm{Sr}$, respectively. Because tritium is highly mobile and would not have settled out of the creek water, the cumulative activity shown in figure 11 is only indicative that $70 \%$ of the tritium has decayed; it implies nothing regarding the distribution of tritium in the environment. In contrast the movement of ${ }^{90} \mathrm{Sr}$ and particularly ${ }^{137} \mathrm{Cs}$ can be retarded by sorption. The ${ }^{137} \mathrm{Cs}$ overflight data and sediment analyses from the IOU database indicate the presence of ${ }^{137} \mathrm{Cs}$ in the Steel Creek bed (figure 12). Although only a few locations in the IOU database had analytical data for ${ }^{90} \mathrm{Sr}$, available sediment data for Steel Creek did not indicate the presence of ${ }^{90} \mathrm{Sr}$ near the discharge pipes into the creek. The cumulative activities, as shown in figures 14 and 15, show that the activities of ${ }^{137} \mathrm{Cs}$ and ${ }^{90} \mathrm{Sr}$ have decreased by $50 \%$ and indicate that where these contaminants are found in the creek bed, they are depleting sources. The geochemical behavior and sorption characteristics of these radionuclides, particularly ${ }^{137} \mathrm{Cs}$, would be an important consideration in the design of any treatment system in this area. 


\section{Seepage Basins}

Figure 16 shows the annual curies of tritium originally discharged from P Reactor to the seepage basins with Steel Creek for comparison. As indicated in the figure, Steel Creek received the majority of the tritium activity discharged from P Reactor. However, these releases occurred primarily in the early and middle part of the reactor's history (1954 through 1978) and had a primary pathway downstream toward the Savannah River. In addition, these releases were usually accompanied by large volumes of water. As indicated by release volume histories, Steel Creek typically received two orders of magnitude more liquid effluent annually than the seepage basins (figure 17) (14). In contrast, the seepage basins received most of the tritium activity toward the latter part of the reactor's history (1978 through 1987) accompanied with less volume of effluent water. The lower discharge volumes coupled with the closed system of the basins (i.e. not intermixing with fresh water) would have led to high concentrations of tritium (among other radionuclides) in the seepage basins with a greater potential to locally affect P Area groundwater than the discharges to Steel Creek.

Monitoring wells around the seepage basins were installed in 1978 (and later replaced in 1984). Tritium data collected from these wells during the early and mid-1980's appear to be similar to the calculated concentrations of tritium released to the seepage basins from 1978 through 1989 (figure 18). Tritium concentrations were calculated using historical activity release data and discharge volume data (14). In figure 18, the bottom error bars for the seepage basin discharges represent the decayed tritium concentration. Historically, PSB1 (PSB1A), which is on the downgradient side of seepage basin \#1, has had the most elevated tritium concentrations followed by PSB2 (PSB2A), PSB3 (PSB3A) and PSB7 (PSB7A). Analyses of sediments below the seepage basins also indicate that seepage basin $\# 1$ received the greatest amount of discharged radionuclides, followed by seepage basin \#2, and then seepage basin \#3 (21).

Figure 19 provides a more detailed view of monitoring well data and seepage basin releases beginning in 1978 through 1999. A decayed concentration of the last recorded release has been calculated and is shown in figure 19 as a dashed line. This concentration of the last release can be used as a worst case concentration emanating from the seepage basins into the groundwater assuming no mixing or dispersion. Beginning in the early 1990's, tritium concentrations in the monitoring wells started decreasing and by 1999 reached concentrations significantly less than the decayed concentration of the last release. This difference indicates that the seepage basins are a depleting source of tritium.

Releases of two of the longer-lived radionuclides, ${ }^{137} \mathrm{Cs}$ and ${ }^{90} \mathrm{Sr}$, to the seepage basins were also considered and are presented in figures 20 and 21 (14). Compared to Steel Creek, the seepage basins received fewer curies ${ }^{137} \mathrm{Cs}$ and ${ }^{90} \mathrm{Sr}$. As documented in the November 2002 Technical Evaluation Report for the P Area Seepage Basins, much of the ${ }^{137} \mathrm{Cs}$ and some of the ${ }^{90} \mathrm{Sr}$ discharged to the seepage basins remain distributed in sediments below the basins. More specifically, analyses of soil sample borings revealed that ${ }^{137} \mathrm{Cs}$ contributes approximately $90 \%$ to the total radioactivity found in basins \#1 and 
$\# 2$, and ${ }^{90} \mathrm{Sr}$ contributes approximately $4 \%$ to the total radioactivity in these basins. According to this technical evaluation, most of the radioactivity in basin \#3 is attributable to naturally occurring radionuclides (21). Mass balance analyses of the ${ }^{137} \mathrm{Cs}$ show reasonable closure with the decay corrected amount of ${ }^{137} \mathrm{Cs}$ released to the basins closely matching the amount of ${ }^{137} \mathrm{Cs}$ remaining in the sediments of basins \#1 and \#2 (Appendix D). This is an indication that the ${ }^{137} \mathrm{Cs}$ released to the basins have been held in the soils. Thus, closure of the basins per the Plug-In ROD will eliminate a potential source of groundwater contamination.

The majority of ${ }^{137} \mathrm{Cs}$ and ${ }^{90} \mathrm{Sr}$ released to the seepage basins occurred in 1959 early in $\mathrm{P}$ Reactor's history. Weekly monitoring reports for this year suggest that an atypical discharge of a failed element and the handling of developmental reactor fuels may have contributed to the increased releases of radionuclides to P Reactor's seepage basins. In particular, in March 1959, a failed element was transferred to the emergency section of the disassembly basin but not contained in the "harp" (the container used to store failed elements underwater). According to weekly reports, the water from the emergency section was pumped into the seepage basins where subsequent large concentrations of radioactivity were found $(22,23)$.

In addition to discharge incidents, $\mathrm{P}$ Reactor disassembly basin handled Spent Canadian Reactor Uranium Products (SCRUP) casks in 1959 and 1960 as part of an Atomic Energy Commission program designed to make uranium available as fuel in experimental power reactors and university research reactors. The program mandated that once the fuel was no longer needed or was spent, it was to be returned to the Savannah River Site for reprocessing. The experimental fuel elements were diverse in dimensions, types of cladding, and nature of the fuel cores. Before the Receiving Basin for Off-site Fuels (RBOF) was built in 1964, P Area received some of the early fuel elements from the Canadian heavy water reactors $(4,24)$. According to weekly monitoring reports, ${ }^{137} \mathrm{Cs}$ and ${ }^{90} \mathrm{Sr}$ were found to contribute to the high gamma and nonvolatile beta activities in the transfer area of the disassembly basin where these casks were handled. Effluents from the transfer area and from the casks were typically pumped to the seepage basins $(24,25)$.

An overflow of the seepage basins which occurred in October 1959 would also suggest that the basins were receiving extensive use during this period. As documented in a weekly monitoring report, water levels in seepage basin \#2 were found over the berm producing an "outcrop" of water extending approximately 45 feet from the basin. Tritium analyses of water collected from the outcrop were $0.440 \mathrm{uC} / \mathrm{L}(440 \mathrm{pC} / \mathrm{mL})$ confirming that the water originated from the basin (26). 


\section{Summary of Findings}

The major findings and implications from this source term determination are presented below.

- A calcareous zone exists with numerous and erratic solution channels under P Area. The average top of this zone is approximately $175 \mathrm{ft}$ below land surface in $\mathrm{P}$ Area and was found to vary between 10 and $40 \mathrm{ft}$ thick. The data indicate that this zone is in the Lower Aquifer Zone (LAZ) of the Upper Three Runs Aquifer. The dissolution channels of this calcareous zone can act as preferential pathways of contaminant transport should a contaminant reach this zone. Additionally, the amount and distribution of grout from the Corps of Engineers foundation grouting has the potential to affect chemistry and transport behavior below P Reactor.

- This document search did not find any major abnormal release events/accidents that would have caused a substantial release to the ground surface or surface water bodies.

- The releases that accompanied normal operations during P Reactor's long operational history may have the most impact on the distribution and types of contaminants found.

- The 704-P maintenance shop is a potential source of organic solvents due to the heavy use of solvents in this building. Standard practice for disposal of organic solvents in the maintenance shops consisted of discarding drummed waste onto the ground 50 to 100 yards from the building.

- Before 1978, P Area discharged the majority of the tritium activity to Steel Creek whereas from 1977 through 1987, the seepage basins received most of the tritium activity. A greater volume of water was discharged to Steel Creek than the seepage basins which would have decreased the concentration of tritium (and other contaminants) discharged. With tritium's low sorption potential and nonreactive nature, the large volumes of water would also have carried the tritium downstream toward the Savannah River reducing the likelihood that it would affect groundwater near P Area. In contrast, the closed system of the seepage basins provided a longer term source of tritium to the groundwater. With no current source from the basins, local hydrogeologic properties and decay would determine tritium migration.

- P Area discharged most of the ${ }^{137} \mathrm{Cs}$ activity to Steel Creek rather than the seepage basins and most of the ${ }^{137} \mathrm{Cs}$ was released during the 1960's. The high retardation potential of Cs coupled with the variability of discharges and erosional/depositional episodes associated with the creek would likely make its distribution partly scattered in surficial sediments along Steel Creek. Gamma overflight data and sediment data indicate that some of the ${ }^{137} \mathrm{Cs}$ remains along Steel Creek. ${ }^{137} \mathrm{Cs}$ discharged to the seepage basins would tend to remain bound to sediments near the bottoms of the seepage basins as evidenced by analyses of sediments below the basins.

- Like ${ }^{137} \mathrm{Cs}$, most of the ${ }^{90} \mathrm{Sr}$ discharged from P Area was released to Steel Creek during the 1960's. Most of the ${ }^{90} \mathrm{Sr}$ traveled relatively quickly to the Savannah River after being discharged. The migration of any ${ }^{90} \mathrm{Sr}$ deposited would have likely been affected by adsorption to clay minerals, metal oxides and organic 
matter. Relative to Cs, Sr tends to sorb and desorb easily and would have had a greater potential to migrate.

\section{References}

1. "Report of Preliminary Studies Foundation Investigations, Savannah River Plant", conducted for The Atomic Energy Commission and E.I. DuPont de Nemours \& Co. by Charleston District Corps of Engineers, U.S. Army, Report \#1, Report prepared and published by Waterways Experiment Station, Corps of Engineers, U.S. Army, Vicksburg, Mississippi, March 1951, Volume 1.

2. "Foundation Grouting Operations, Savannah River Plant", conducted for The Atomic Energy Commission and E.I. DuPont de Nemours \& Co. by Charleston District Corps of Engineers, U.S. Army, Report \#1, Report prepared and published by Waterways Experiment Station, Corps of Engineers, U.S. Army, Vicksburg, Mississippi, June 1952.

3. Savannah River Site at Fifty, by M. B. Reed, M. Swanson, S. Gaither, J.W. Joseph, and W. Henry, published by U.S. Government Printing Office, Washington, D. C., 2002.

4. History of DuPont at the Savannah River Plant, by W.P. Bebbington, published by E.I. DuPont de Nemours \& Co., Wilmington, Delaware, 1990.

5. "Final Report Savannah River Site Dose Reconstruction Project: Phase II: Source Term Calculation and Ingestion Pathway Data Retrieval, Evaluation of Materials Released from the Savannah River Site", conducted for the Centers for Disease Control and Prevention by Risk Assessment Corporation, 2001.

6. "Memo to File RE: Phone conversation with Greg Burbage concerning reactor operations", November 21, 2002.

7. "Stabilization of Deteriorating Mark 16 and Mark 22 Aluminum-Alloy Spent Nuclear Fuel at the Savannah River Site", prepared for the Defense Nuclear Facilities Safety Board, DNFSB/TECH-7, 1995.

8. "Assessment of Tritium in the Savannah River Site Environment (U)", by C. E. Murphy, Jr., W. H. Carlton, L. R. Bauer, D. W. Hayes, W. L. Marter, C. C. Zeigler, R. L. Nichols, R. N. Strom, B. R. del Carmen, D. M. Hamby, D. D. Hoel, and D. E. Stephenson, WSRC-TR-93-214.

9. "Assessment of Activation Products in the Savannah River Site Environment (U)", by W. H. Carlton and M. Denham, WSRC-TR-95-0422.

10. "Assessment of Strontium in the Savannah River Site Environment (U)", by W.H. Carlton, A. G. Evans, L. A. Geary, C. E. Murphy, Jr., and R. N. Strom, WSRC-RP92-984.

11. "P-Area Reactor 1993 Annual Groundwater Monitoring Report”, WSRC-TR-940355.

12. "Radioactivity in the Environs of Steel Creek", Radiological Sciences Division, Radiological Chemistry Group, Savannah River Laboratory Monthly Report, August 1972.

13. "Assessment of Radionuclides in the Savannah River Site Environment - Summary (U)”, by W. H. Carlton, WSRC-TR-98-00162. 
14. "Radioactive Releases at the Savannah River Site 1954-1989 (U)" by C. L. Cummins, C. S. Hetrick, and D. K. Martin, WSRC-RP-91-684.

15. "Par Pond Summary", Radiological and Environmental Sciences Division, Savannah River Laboratory Monthly Report, May 1965.

16. "Hydrogeological Analysis and Groundwater Flow for K-Reactor Area with Contaminant Transport Modeling for the K-Area Tritium Plume (U)", by G. P. Flach, L. L. Hamm, M. K. Harris, A. D. Smits, and K. L. Hawkins, WSRC-TR-99-00395, December 1999.

17. "RI Work Plan for the Steel Creek Integrator Operable Unit (U)", WSRC-RP-994151, Final Rev. 1.1.

18. "Reactor Area Disassembly Basin Releases", Health Physics Monthly Environmental Monitoring Report, September 1963.

19. “134,137 Cs in the Savannah River”, Radiological Sciences Division, Savannah River Laboratory, Earth Sciences Monthly Report, March 1970.

20. "Reactor Areas: Liquid Releases", Health Physics, Environmental Monitoring Group Monthly Report, October 1972.

21. "Unit-Specific Plug-In Technical Evaluation Report for the P-Area Reactor Seepage Basins (904-61G, 904-62G, and 904-63G) Operable Unite (U)", WSRC-RP-20024082.

22. "Fuel Element Failures in P and C Areas", Weekly Report - Control, March 9-13, 1959.

23. "Particulate Contamination at the P Area Seepage Basin", Weekly Report - Control, March 16-22, 1959.

24. "Special Analysis", Weekly Report - Control, May 18-22, 1959.

25. "Special Analysis", Weekly Report - Control, September 21-25, 1959.

26. "P Area Seepage Basin”, Weekly Report - Control, October 26-30, 1959. 
WSRC-TR-2003-00142

March 25, 2003

Page 17 of 49

Figure 1 Location of Grouted Boreholes in P Area from Corps of Engineers Foundation Grouting Operations
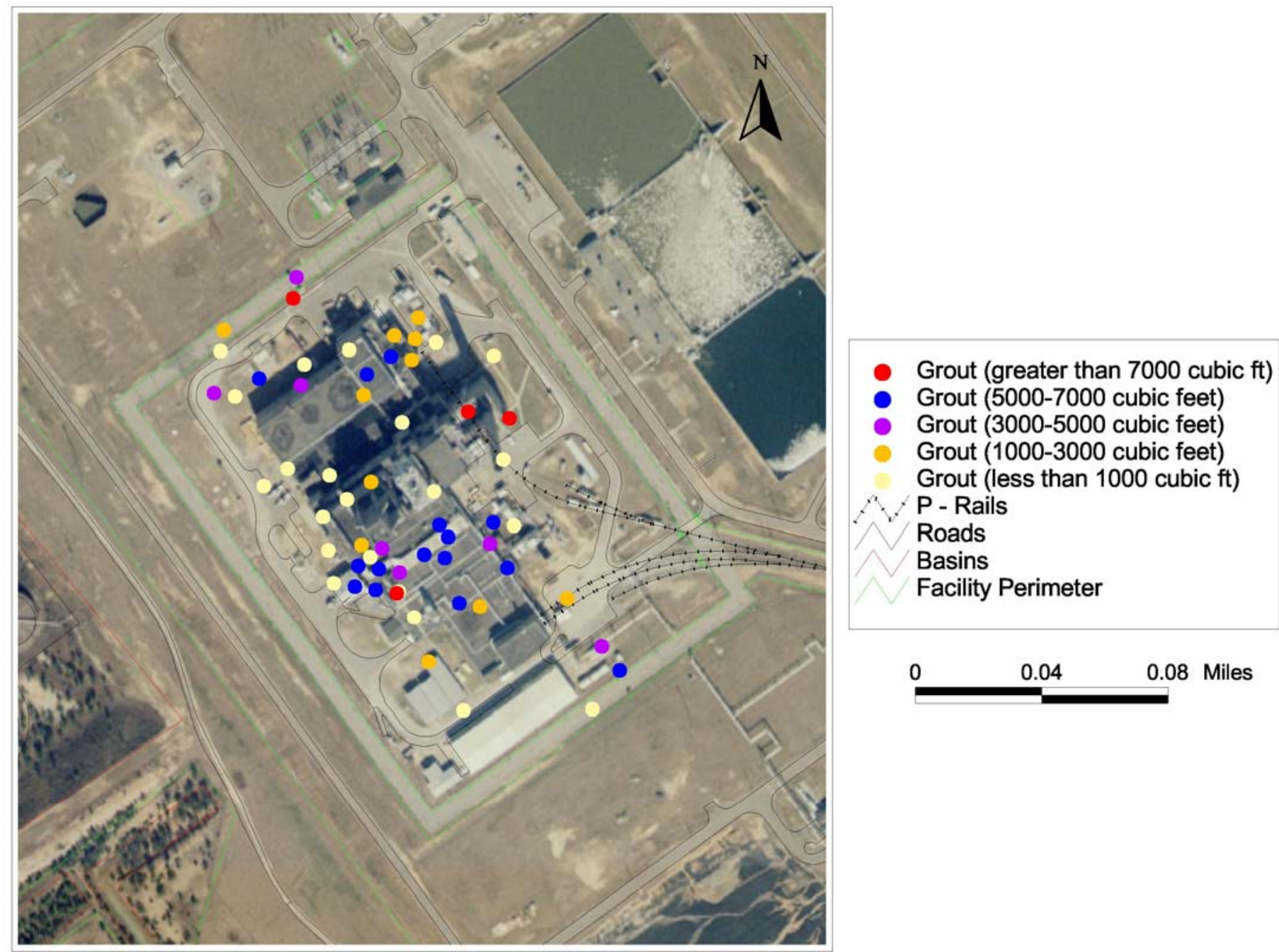

Table 1 Subsurface Characterization and Foundation Grouting Information

\begin{tabular}{|c|c|c|c|c|c|c|c|c|}
\hline & $\begin{array}{c}\text { \# of } \\
\text { borings }\end{array}$ & $\begin{array}{c}\text { \# of split-spoon \& } \\
\text { undisturbed holes }\end{array}$ & $\begin{array}{c}\text { Total \# } \\
\text { of holes }\end{array}$ & $\begin{array}{c}\text { Total \# of } \\
\text { holes grouted }\end{array}$ & $\begin{array}{c}\% \text { of holes } \\
\text { grouted }\end{array}$ & $\begin{array}{c}\text { \# of holes } \\
\text { venting }\end{array}$ & $\begin{array}{c}\text { Qty of grout } \\
\text { pumped (ft3) }\end{array}$ & $\begin{array}{c}\text { \# of borings } \\
\text { indicating } \\
\mathrm{CaCO}_{3}\end{array}$ \\
\hline P Area & 344 & 4 & 348 & 77 & 22 & 24 & 212,783 & 276 \\
\hline L Area & 296 & 8 & 304 & 94 & 31 & 21 & 223,268 & 224 \\
\hline
\end{tabular}


WSRC-TR-2003-00142

March 25, 2003

Page 18 of 49

Figure 2 Power (Thermal) Output for P, R, and L Reactors

\section{P Reactor Power Levels}
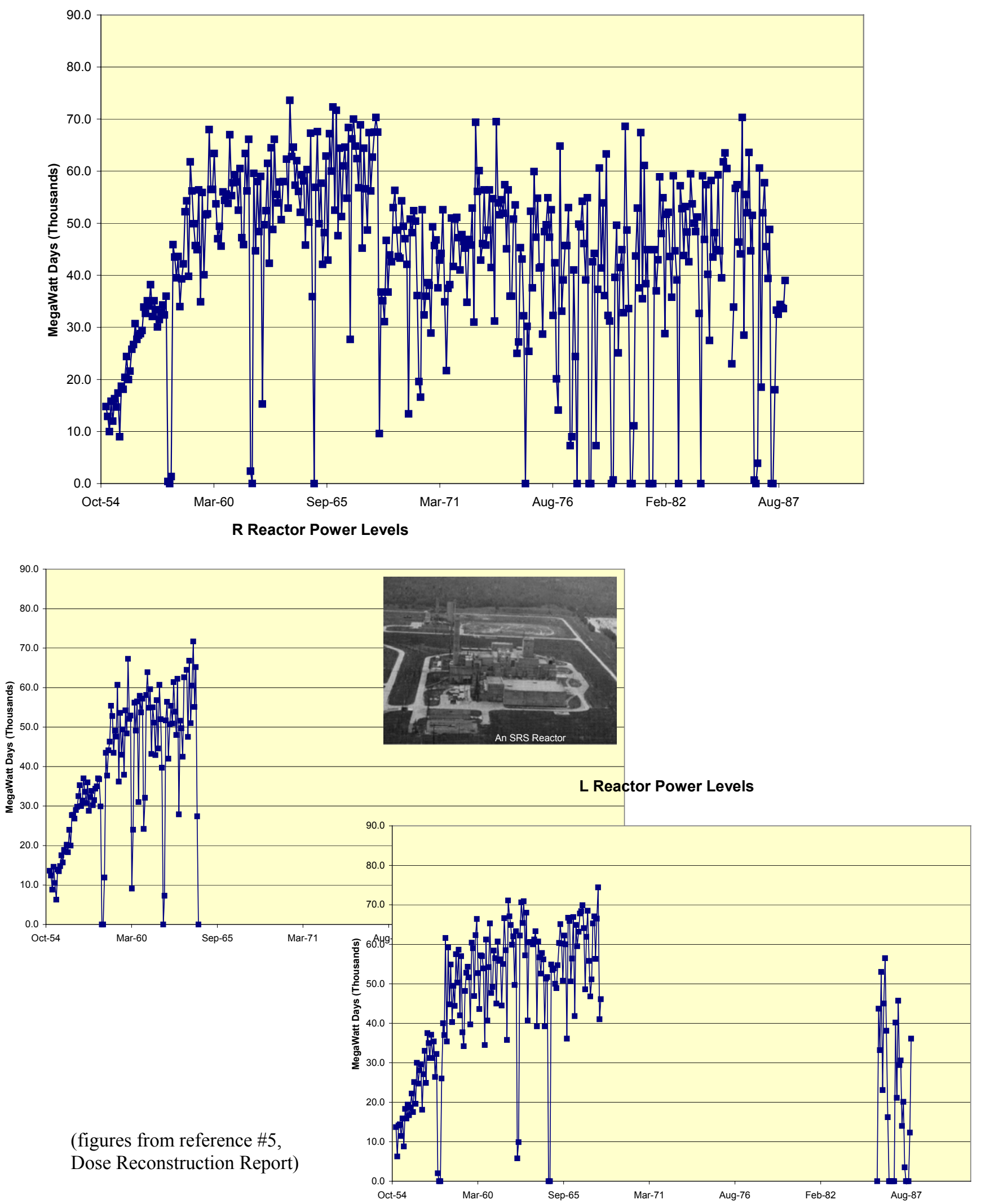
Figure 3 Map of P Reactor Facilities
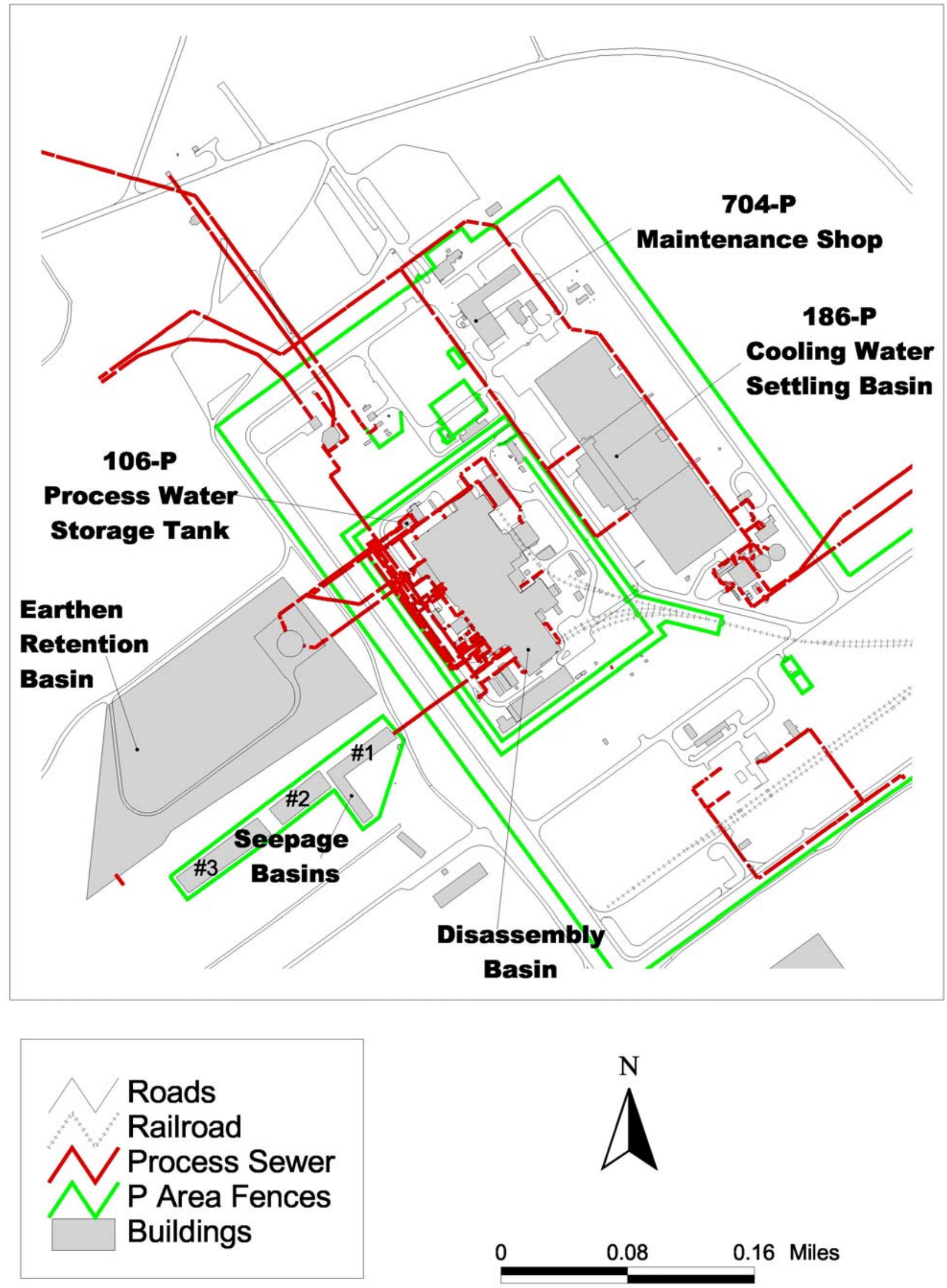
Table 2 Timeline and History for P Reactor

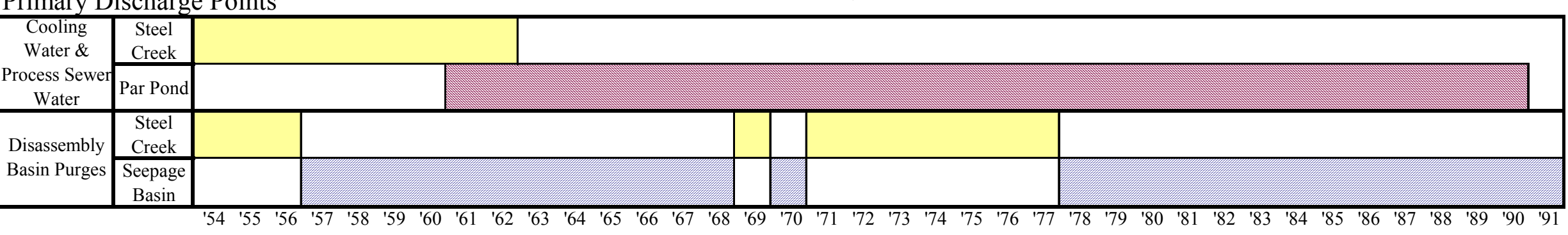

\section{P Area Event History}

\section{1}

P Area ash basin activated; P Area burning rubble pit constructed and activated; Corps of Engineers began soil investigations and subsurface foundation grouting operations

$1954 \quad$ P Reactor started

1955 Acid/Caustic basin activated

1957 Seepage Basins activated

1958 Par Pond completed

1959 P Reactor participated in program for reprocessing spent fuel from other sites (primarily SCRUP, Spent Canadian Reactor Products, casks)

1960 Construction of discharge canal from P Area to Par Pond

1963 Installation of disassembly basin heat exchangers and deionizers; most of cooling and process sewer water diverted to Par Pond; 50 million gallon earthen retention basin constructed for ECS (Emergency Cooling System); in December, P Reactor reached its maximum monthly power output of 73,600 MW days

1969 Seepage basins deactivated; bypassed disassembly basin water filtered and discharged directly to Steel Creek

1978 Seepage basins reactivated; P Area burning rubble pit reaches capacity and closed

1979500,000 gallon storage tank and related piping added to earthen (ECS) rentention basin

1981 P Area coal pile retention basin activated

1982 Acid/Caustic basin deactivated

1985 Construction of L Lake completed; all remaining cooling and process sewer water effluents diverted from Steel Creek

1991 P Reactor placed in shutdown status 
WSRC-TR-2003-00142

March 25, 2003

Page 21 of 49

Table 3 Common Radiological Contaminants

\begin{tabular}{|c|c|}
\hline Source of contaminants & half-life \\
\hline $\begin{array}{l}{ }^{32} \mathrm{P} \text { came from the activation of sulfur leached from moderator deionizers } \\
\text { during normal operations and from the use of phosphoric acid to clean the } \\
\text { heat exchangers in the mid-1960's }\end{array}$ & 14.3 days \\
\hline $\begin{array}{l}{ }^{51} \mathrm{Cr} \&{ }^{60} \mathrm{Co} \text { came from the activation of stable }{ }^{50} \mathrm{Cr} \&{ }^{59} \mathrm{Co} \text { in the stainless } \\
\text { steel parts of the reactor tank and the stainless steel used in the reactor } \\
\text { cooling system piping }\end{array}$ & 27.7 days $\& 5.27$ years \\
\hline $\begin{array}{l}{ }^{65} \mathrm{Zn} \text { came from the activation of }{ }^{64} \mathrm{Zn} \text { a trace element found in the } \\
\text { aluminum reactor fuel and target components }\end{array}$ & 243.9 days \\
\hline $\begin{array}{l}{ }^{137} \mathrm{Cs} \text { formed as a fission product from neutron-induced fission reactions } \\
\text { involving the }{ }^{235} \mathrm{U} \text { fuel elements; additional }{ }^{137} \mathrm{Cs} \text { was formed from the } \\
\text { activation of stable Cs produced by neutron fission }\end{array}$ & 30.1 years \\
\hline${ }^{129}$ I \& ${ }^{131}$ I formed as fission byproducts in the fuel and target elements & $1.57 \mathrm{E}+07$ years $\& 8.04$ days \\
\hline${ }^{90} \mathrm{Sr}$ formed as a fission byproduct in the fuel and target elements & 28.8 years \\
\hline $\begin{array}{l}{ }^{3} \mathrm{H} \text { produced from neutron irradiation of } \mathrm{Li}-\mathrm{Al} \text { targets, interaction between } \\
\text { neutrons and moderator (considered principal source of liquid release), and } \\
\text { by ternary fission (the occasional splitting of } \mathrm{U} \text { atom into three, one of which } \\
\text { was }{ }^{3} \mathrm{H} \text { ) }\end{array}$ & 12.35 years \\
\hline
\end{tabular}


WSRC-TR-2003-00142

March 25, 2003

Page 22 of 49

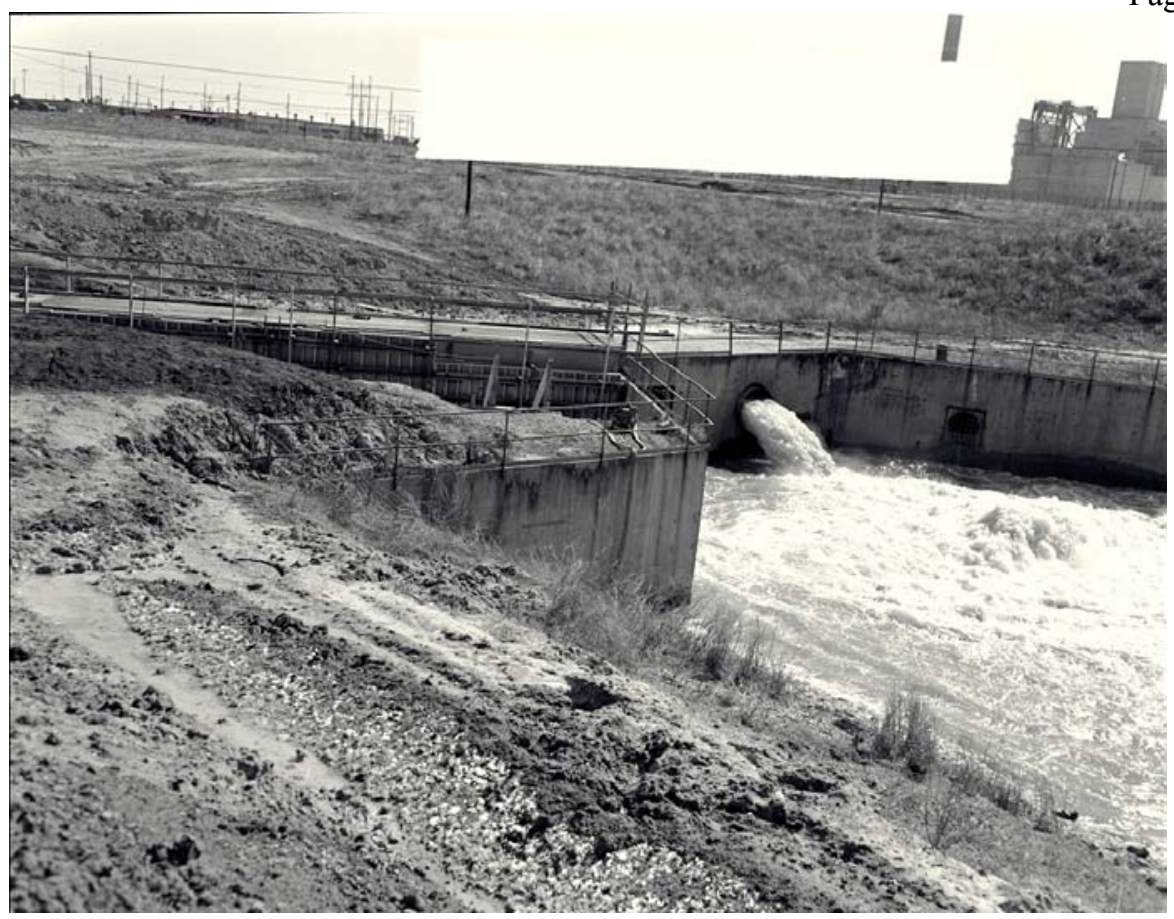

Figure 4 Discharge to Steel Creek

(DPSPF-6580-8) 3/4/1960

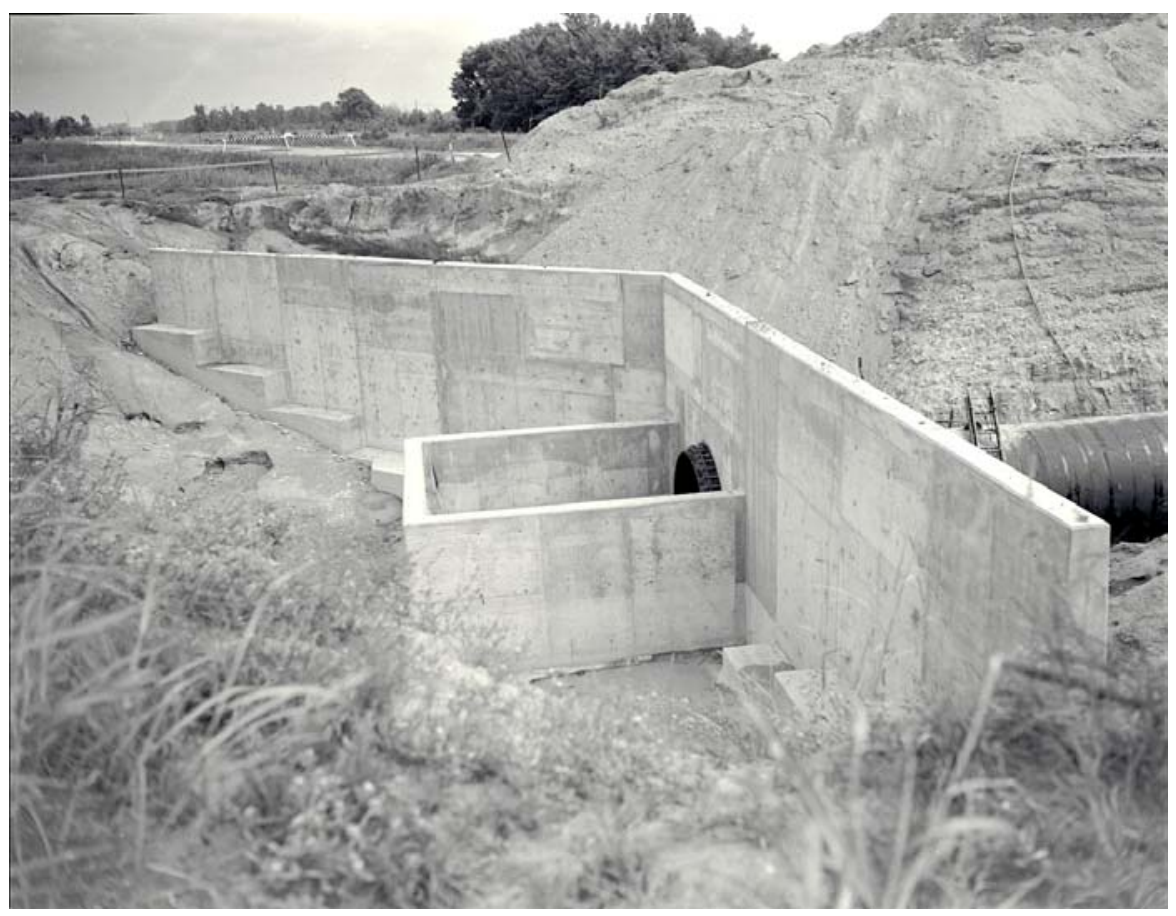

Figure 5 Effluent Stream, P Area

Construction of Discharge Point to Par Pond

(DPSPF-6872-47) 8/17/1960 
WSRC-TR-2003-00142

March 25, 2003

Page 23 of 49

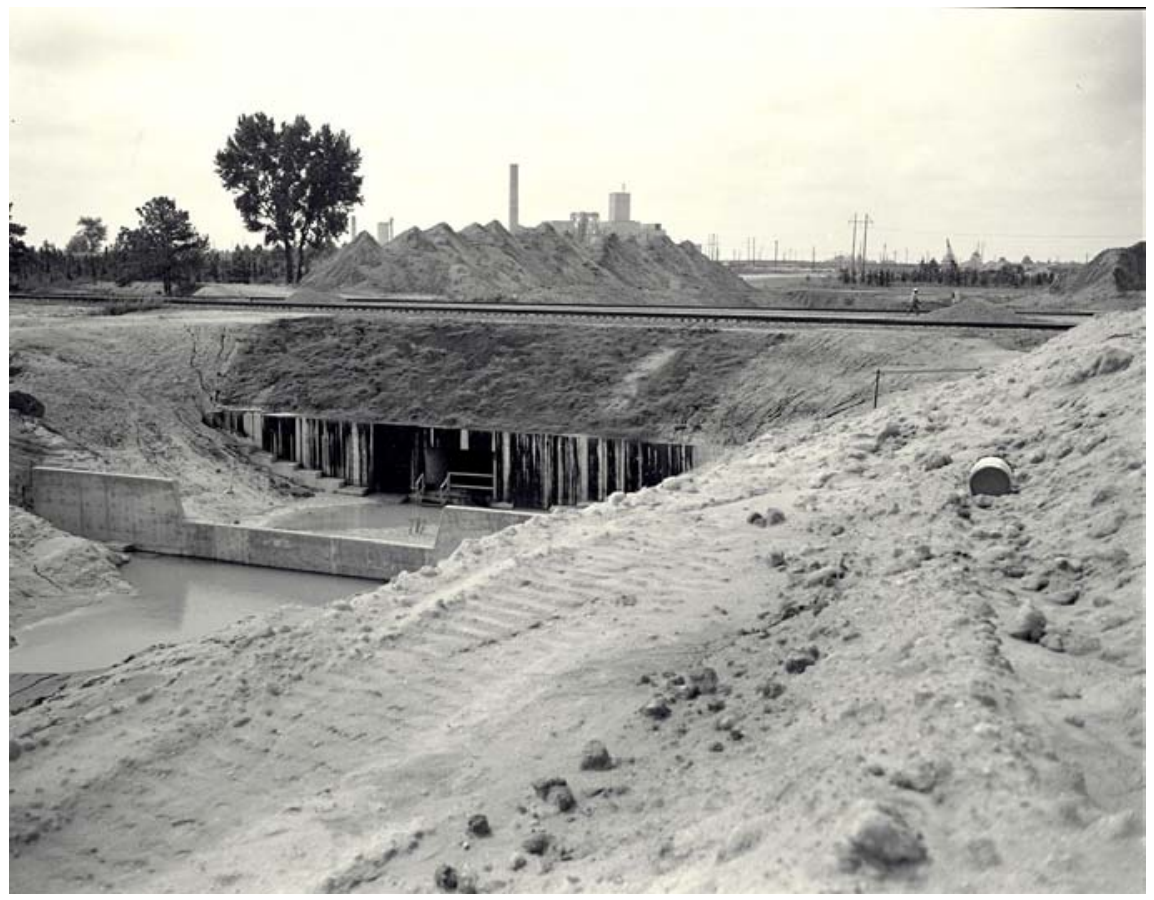

Figure 6 Effluent Stream, P-Area

Construction of P Area Canal to Par Pond

(further downstream from P Area, heading toward Par Pond)

(DPSPF-6872-36) 8/17/1960

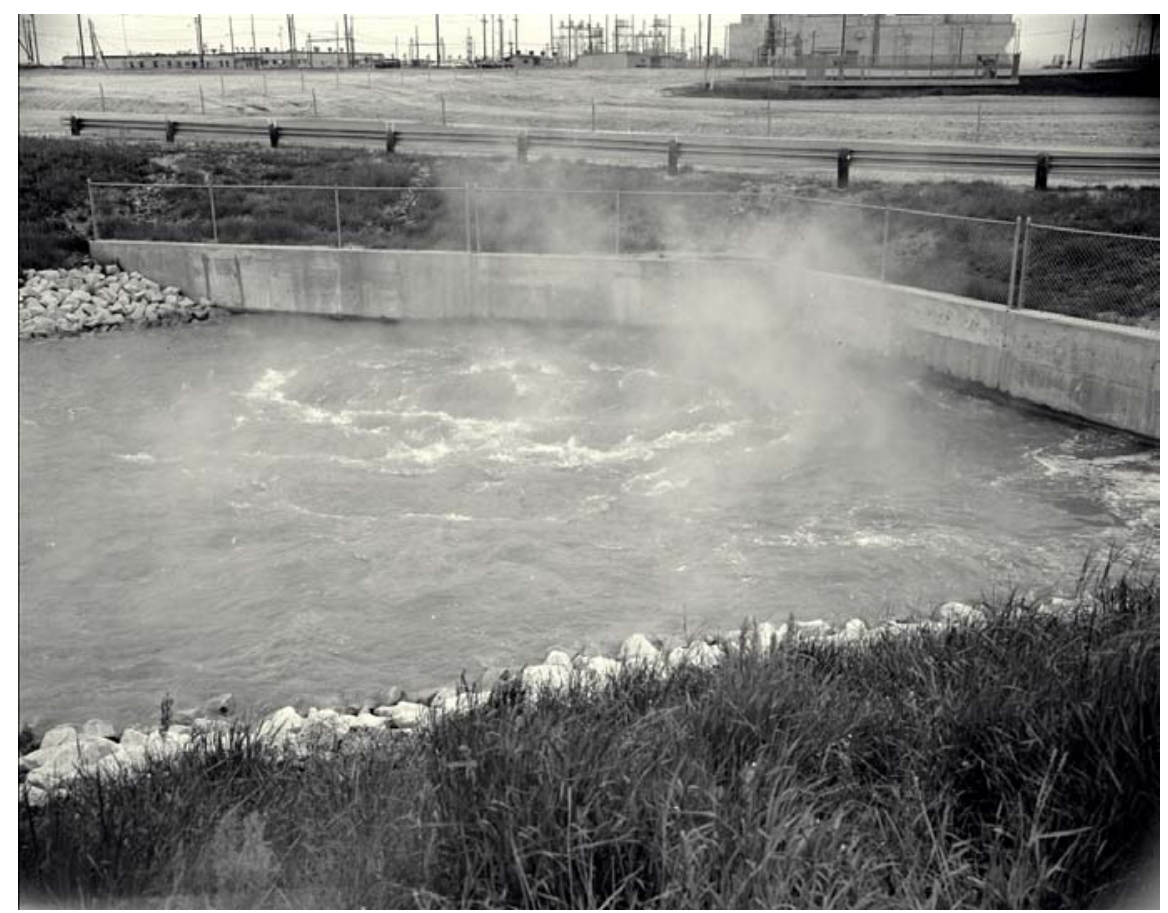

Figure 7 Effluent Canal, P-Area

Discharge Point to Par Pond Completed

(DPSPF-7459-1) 5/5/1961 
WSRC-TR-2003-00142

March 25, 2003

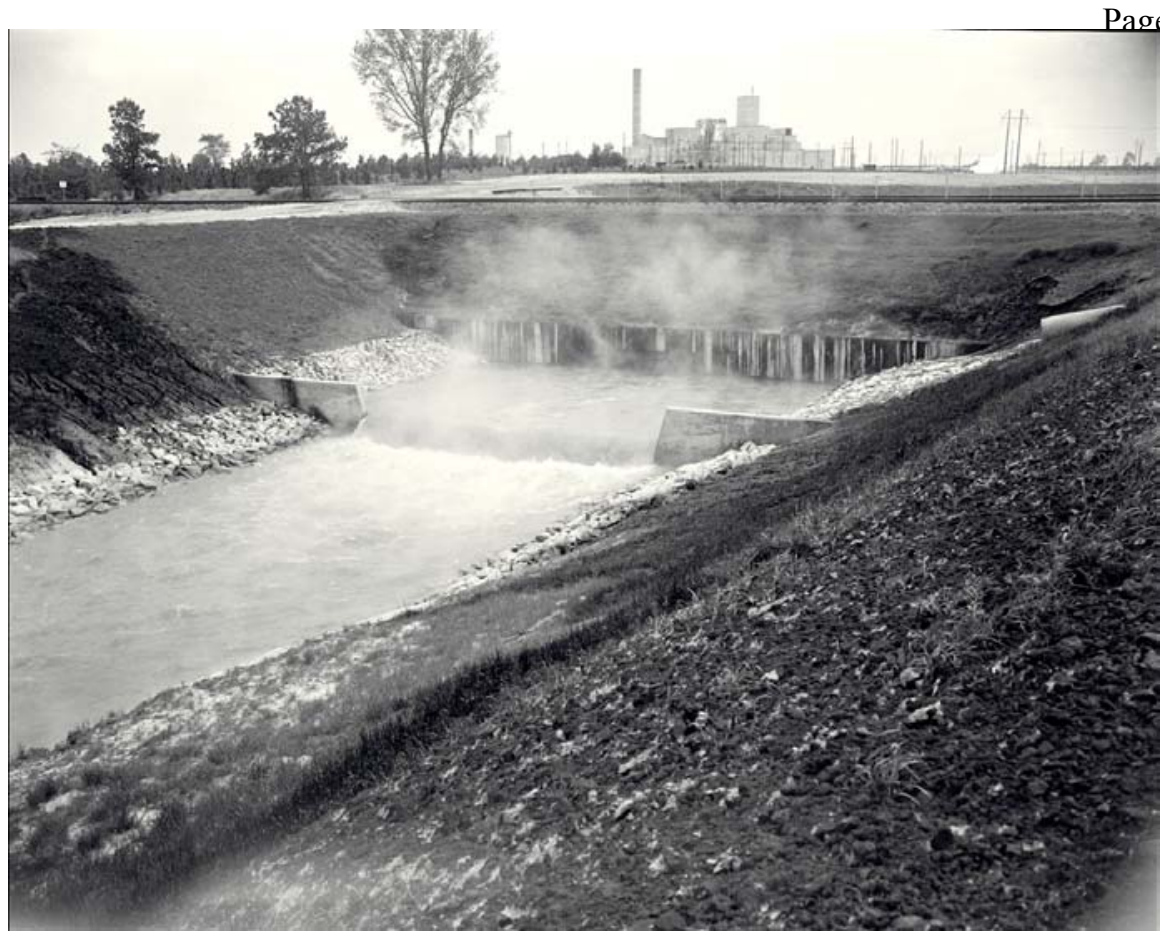

Figure 8 Effluent Canal, P Area

Completion of P Area Canal to Par Pond

(further downstream from P Area, heading toward Par Pond)

(DPSPF-7459-5) 5/5/1961

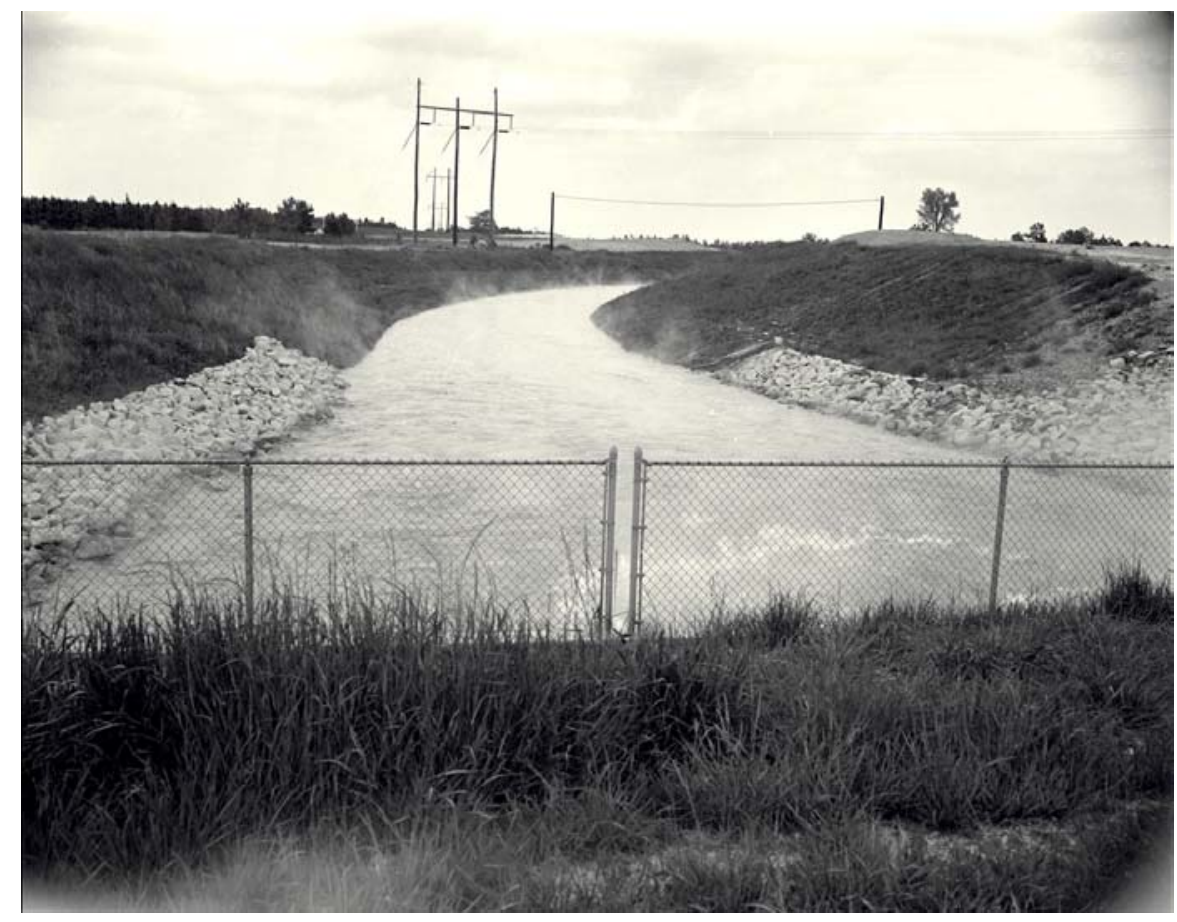

Figure 9 Effluent Canal, P-Area

Looking downstream toward Par Pond (DPSPF-7459-2) 5/5/1961 
WSRC-TR-2003-00142

March 25, 2003

Page 25 of 49

Figure 10 P and L Reactor Releases to Stream (Steel Creek) Tritium Activity Originally Released

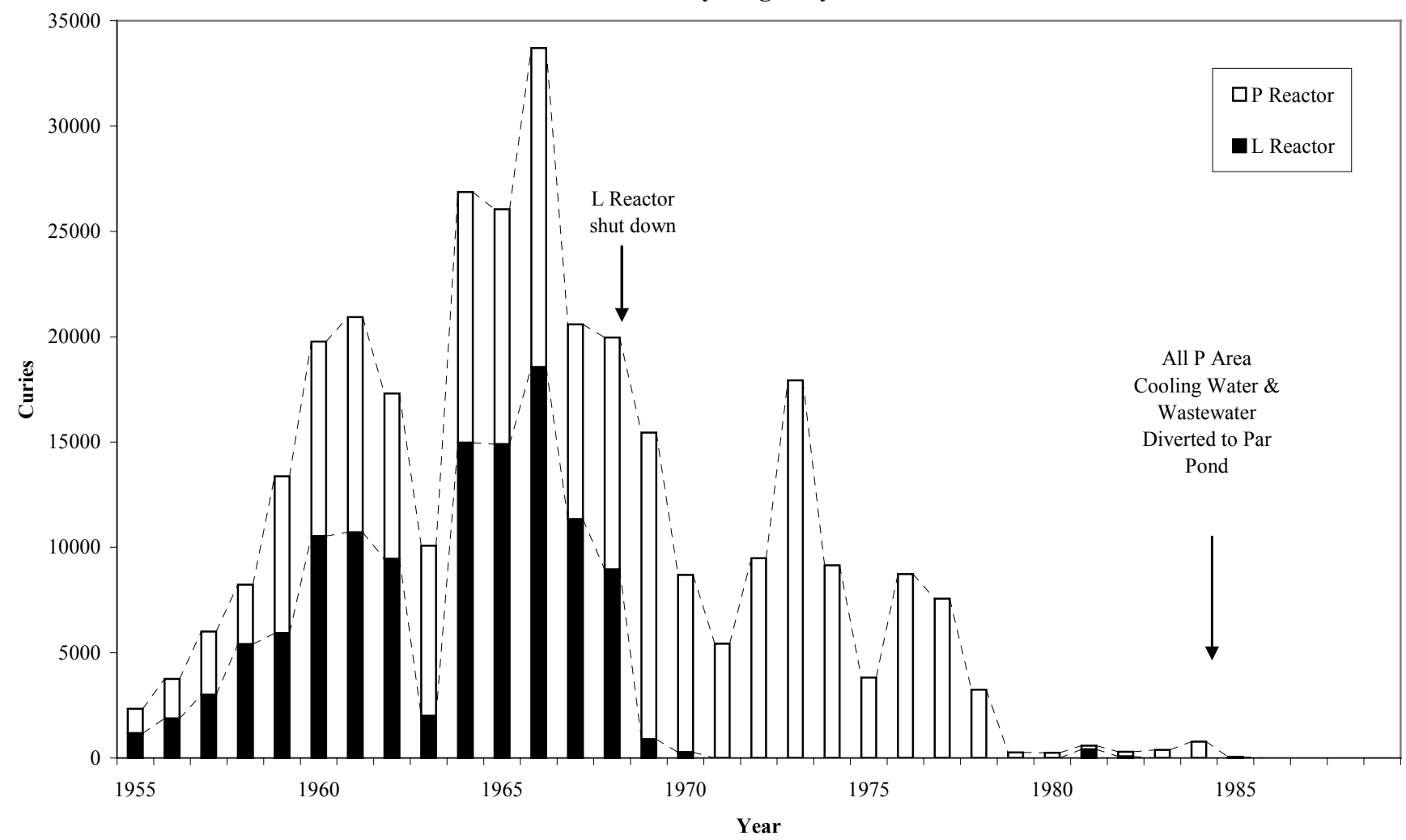

Figure 11 Tritium Released to Stream (Steel Creek)

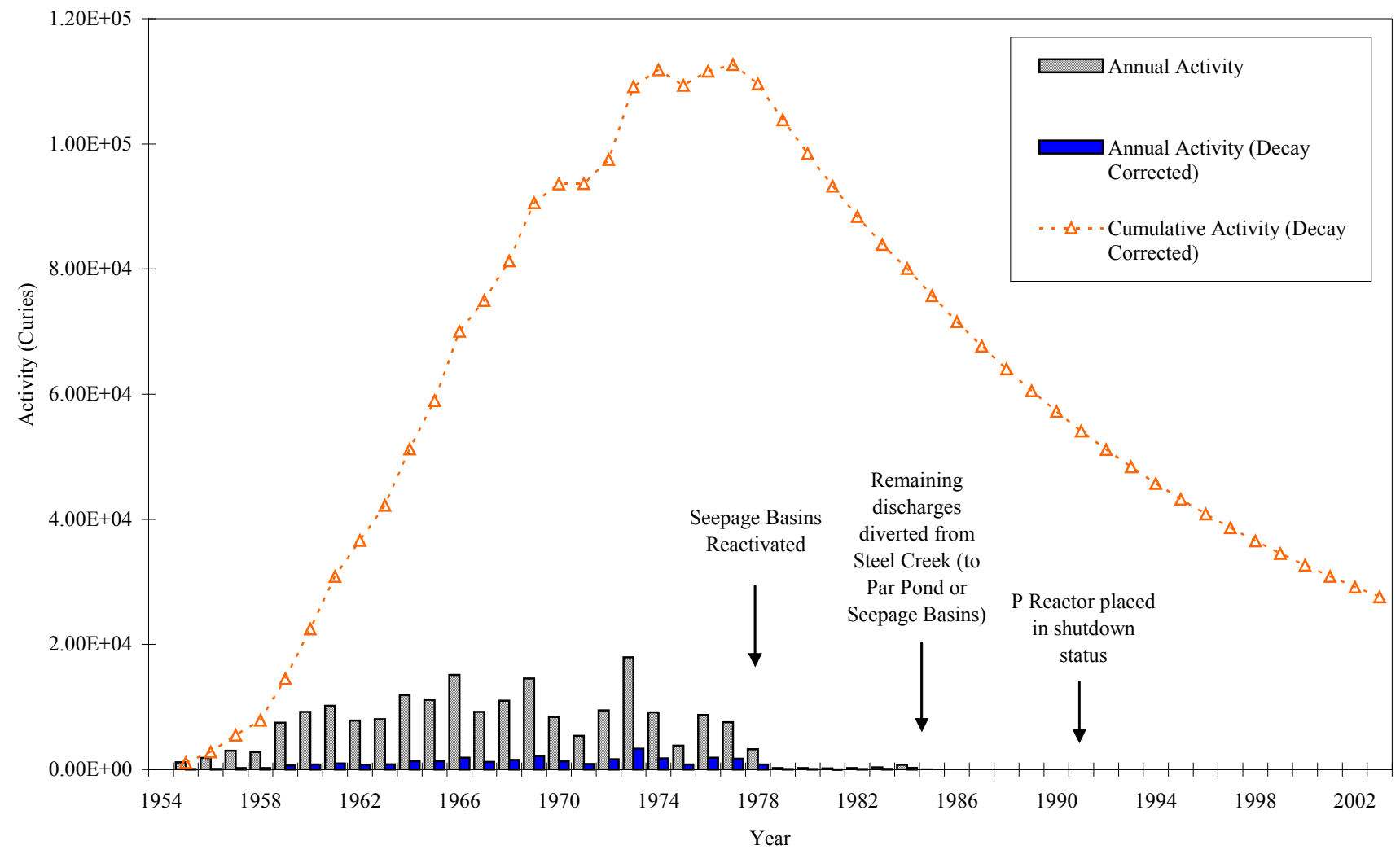




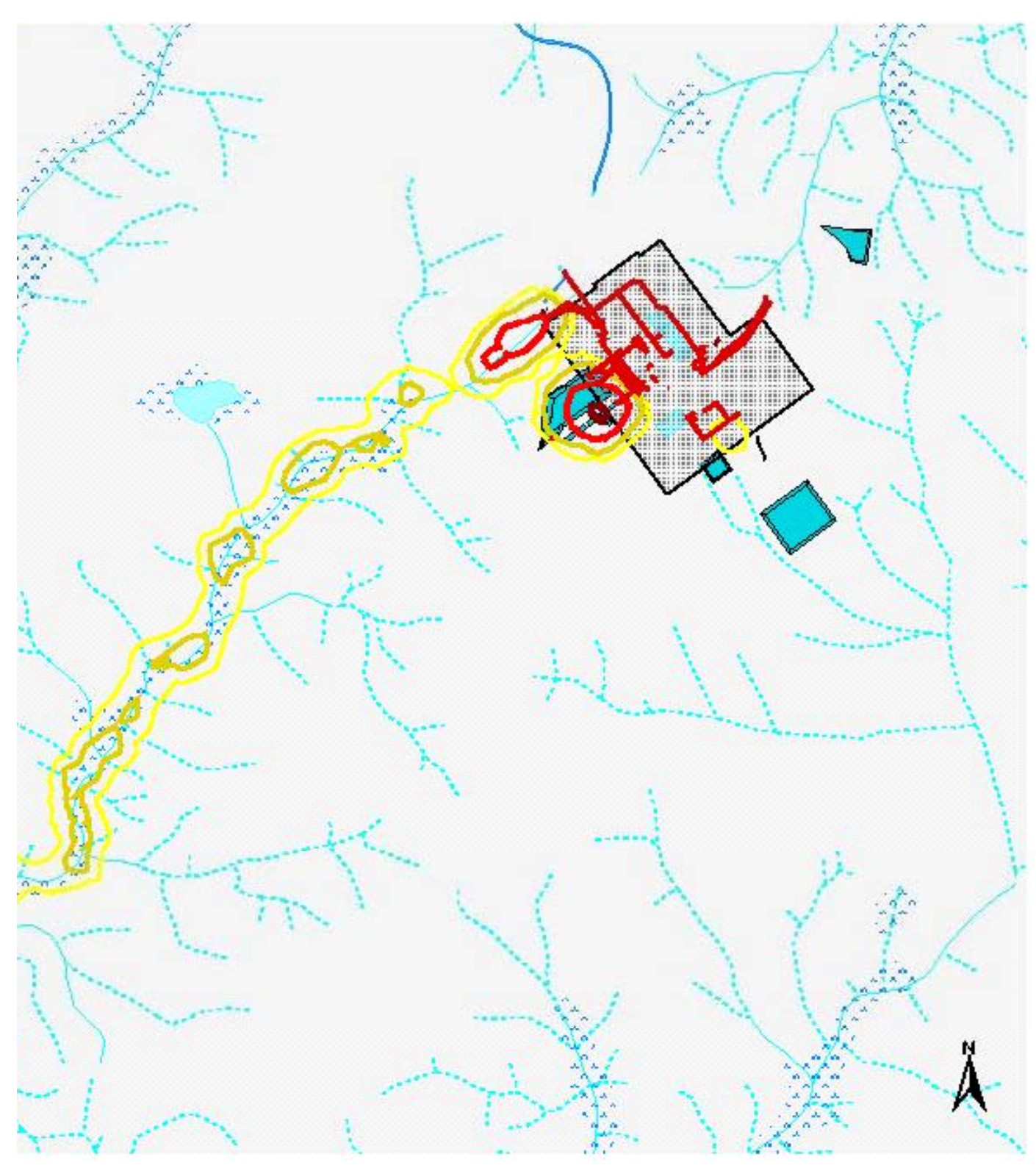

Figure 12

1985 Gamma Overflight Data (obtained from GIS database)

\section{Legend}

AWaste Units (Trenches) Cesium-137 Counts (1985)

A $\begin{array}{r}93 \text { ps } \\ 352 \text { pos }\end{array}$

N1591 pps

Ainility Facilyas

Basins

Waterbodies, USGS 1:24,000 Lakeipond Peremial Stream-Perenial

"MarswSwamp - Wooded Marstuswamp

Streams, USGS 1:24,000

$$
\begin{aligned}
& \text { Intermittent } \\
& \text { Peremial }
\end{aligned}
$$

Perenial

\section{$0 \quad 10002000$ Feet}




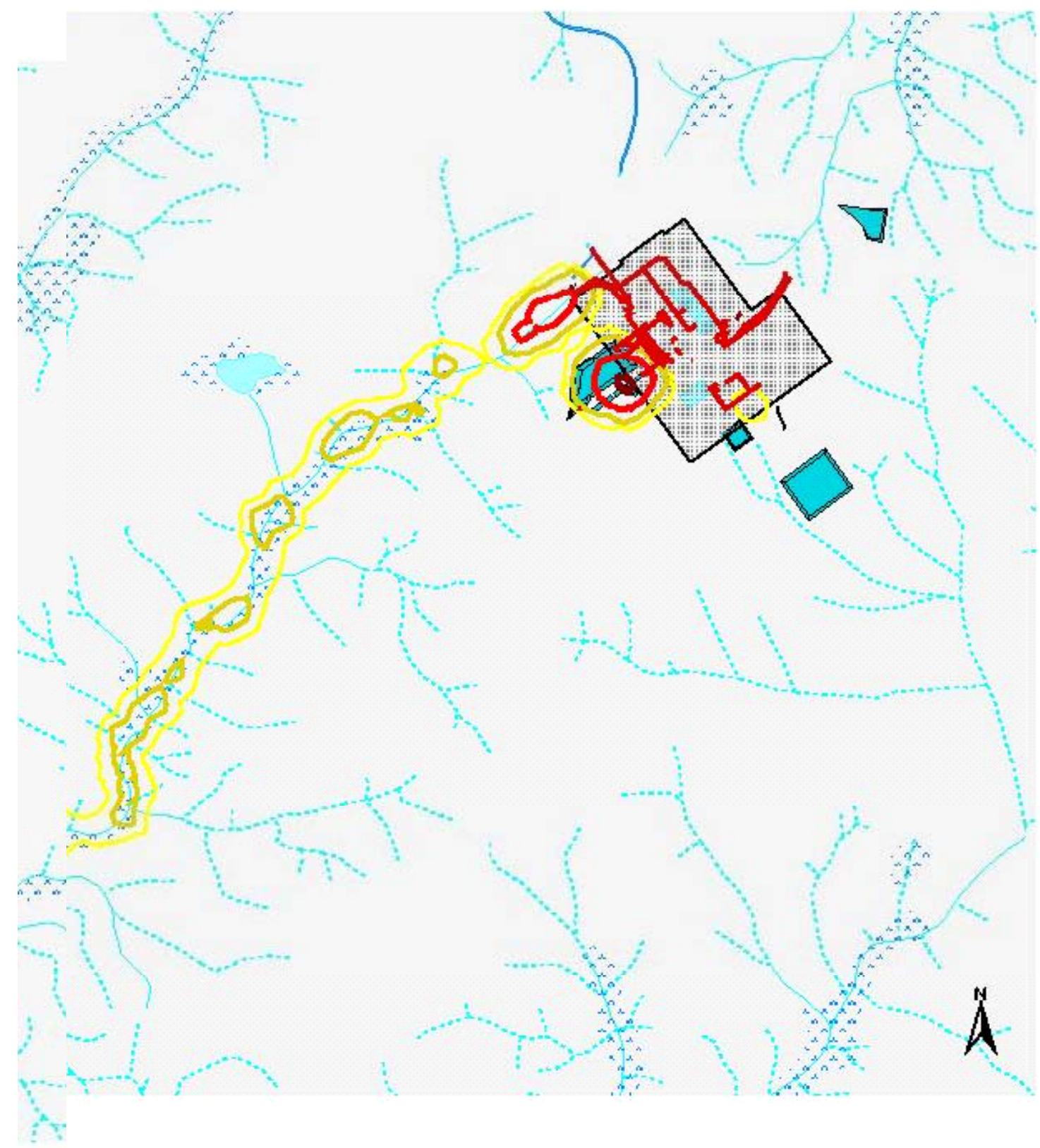

Figure 13

1991 Gamma Overflight Data (obtained from GIS database)

\author{
Legend \\ Waste Units (Trenches) \\ Cesium-137 Counts (1985) \\ A3 cps \\ $\mathcal{N}_{7400}^{15910 \mathrm{pos}}$ \\ A.inil Facility Areas \\ Basins \\ Waterbodies, USCS 1:24,000 \\ Lakeipond Peremia \\ Stream-Perenial \\ Marshiswamp - Wooded \\ Marstiswamp \\ Streans, U\$S\$ 124,000 \\ intermittent \\ Peremial

\section{$0 \quad 10002000$ Feet}


WSRC-TR-2003-00142

March 25, 2003

Page 28 of 49

Figure $14{ }^{137}$ Cs Released to Stream (Steel Creek)

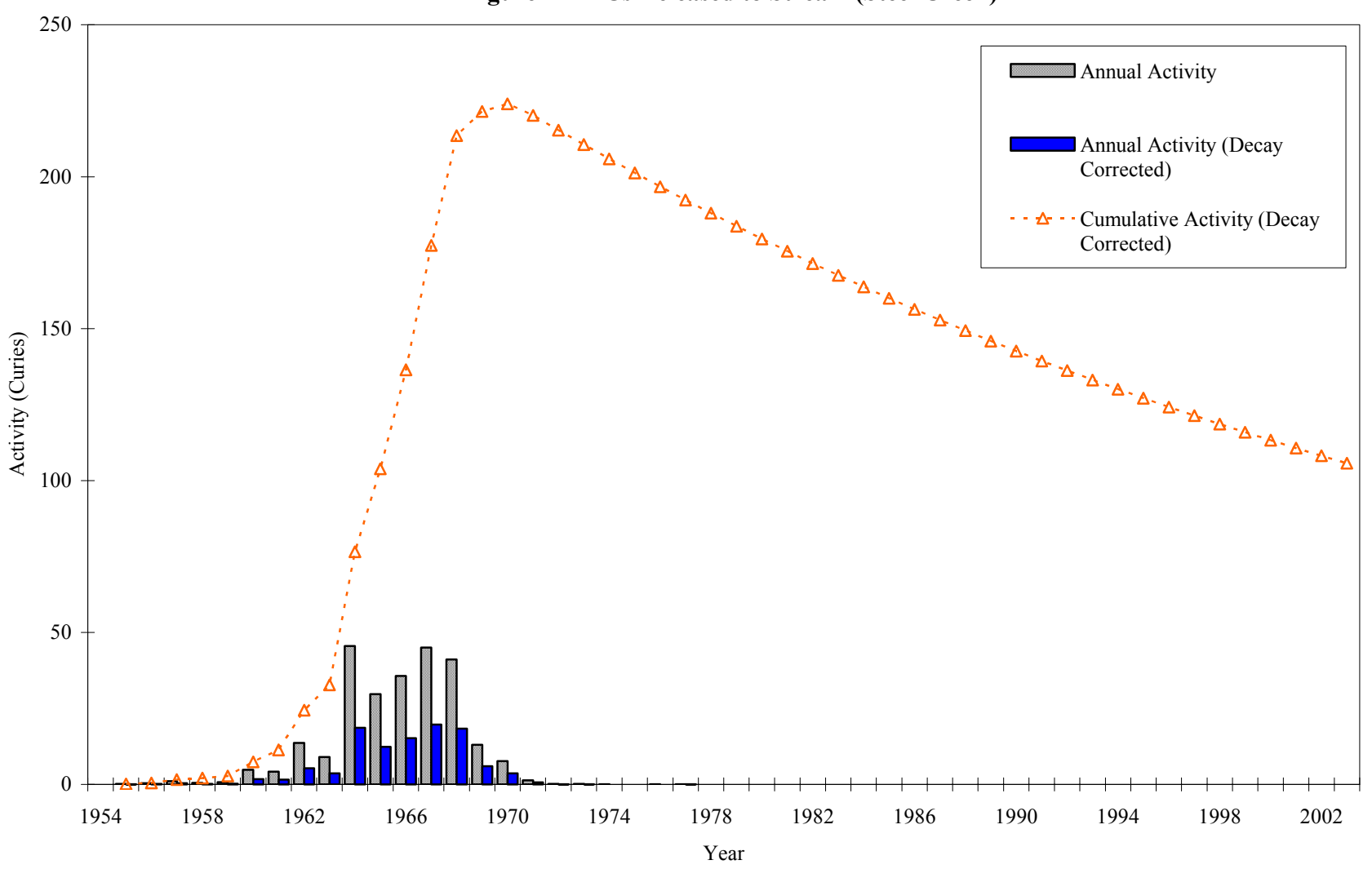

Figure $15{ }^{90} \mathrm{Sr}$ Released to Stream (Steel Creek)

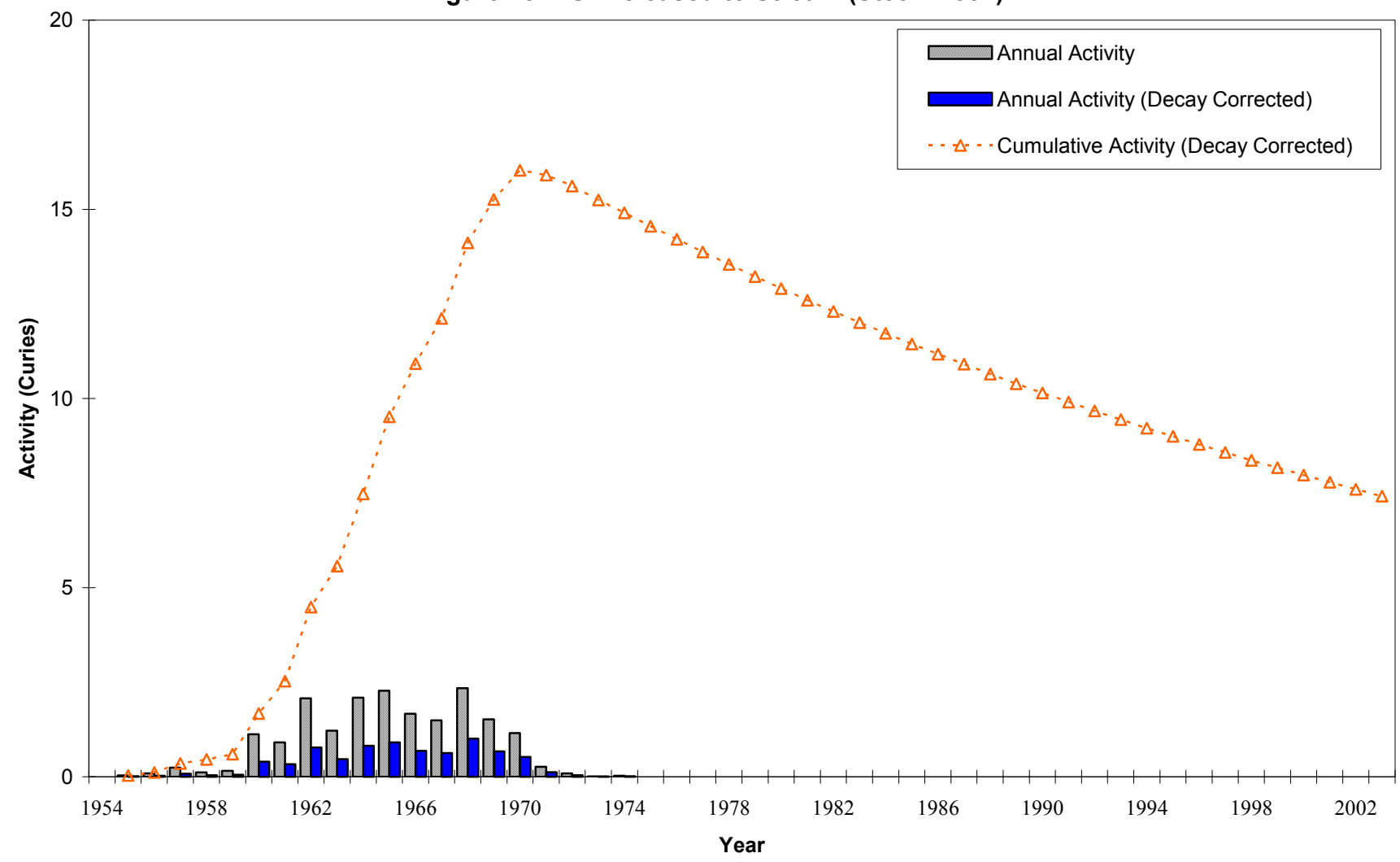


WSRC-TR-2003-00142

March 25, 2003

Page 29 of 49

Figure 16 Annual Tritum Activity Released to Steel Creek and to Seepage Basins

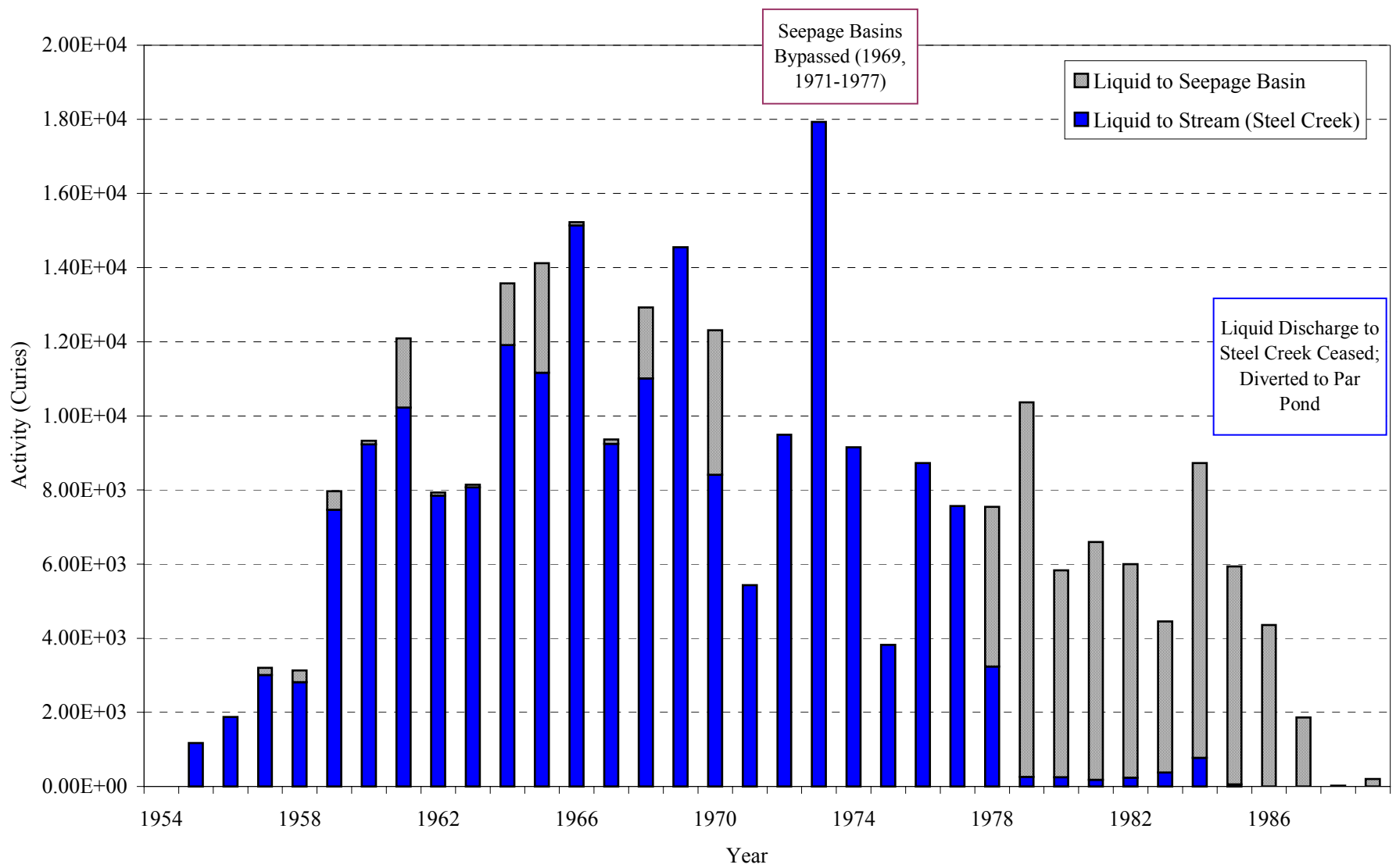

Figure 17 Annual Effluent Volumes Released to Steel Creek and to Seepage Basins

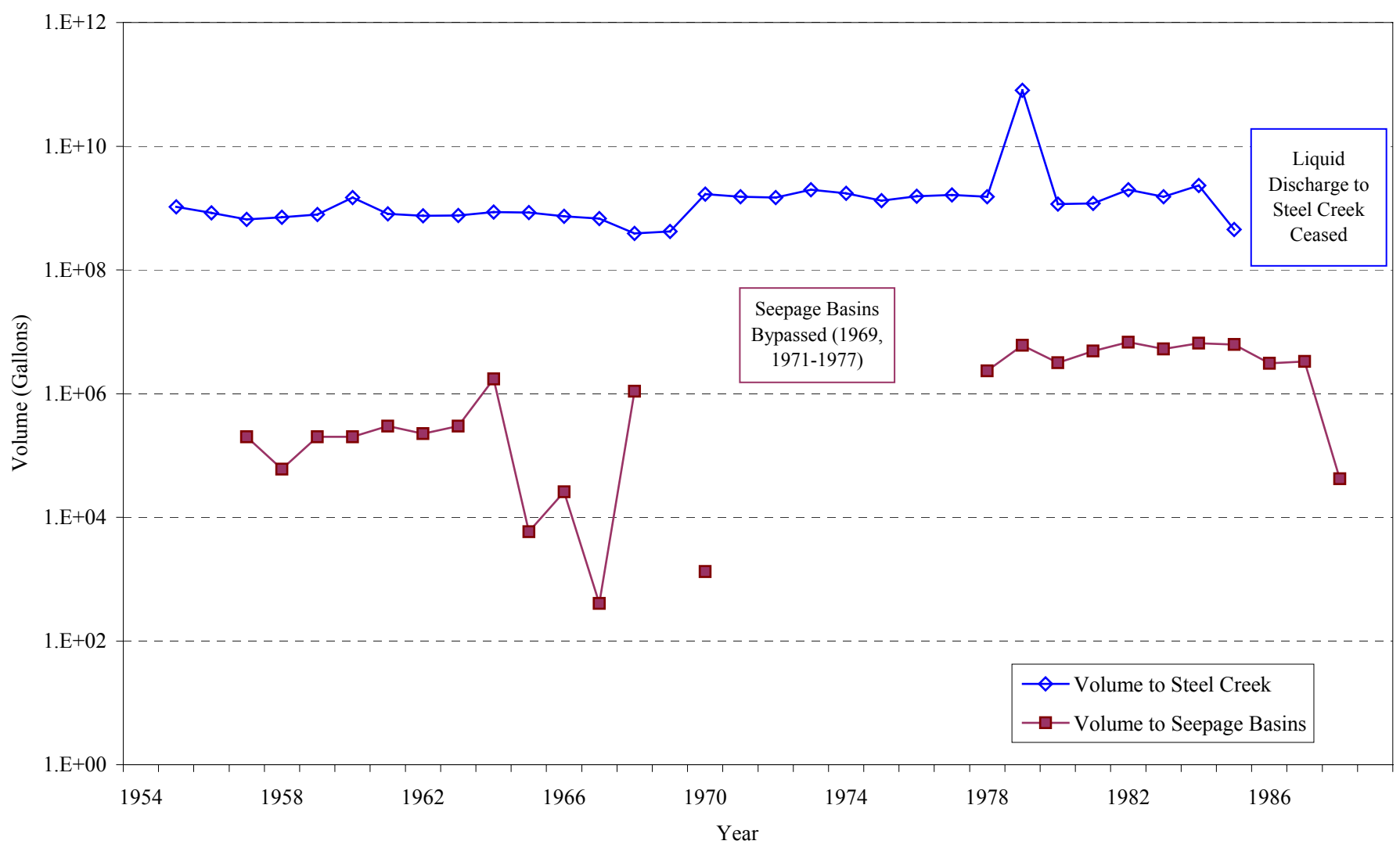


WSRC-TR-2003-00142

March 25, 2003

Figure 18 Tritium in Seepage Basins and PSB Wells

Page 30 of 49

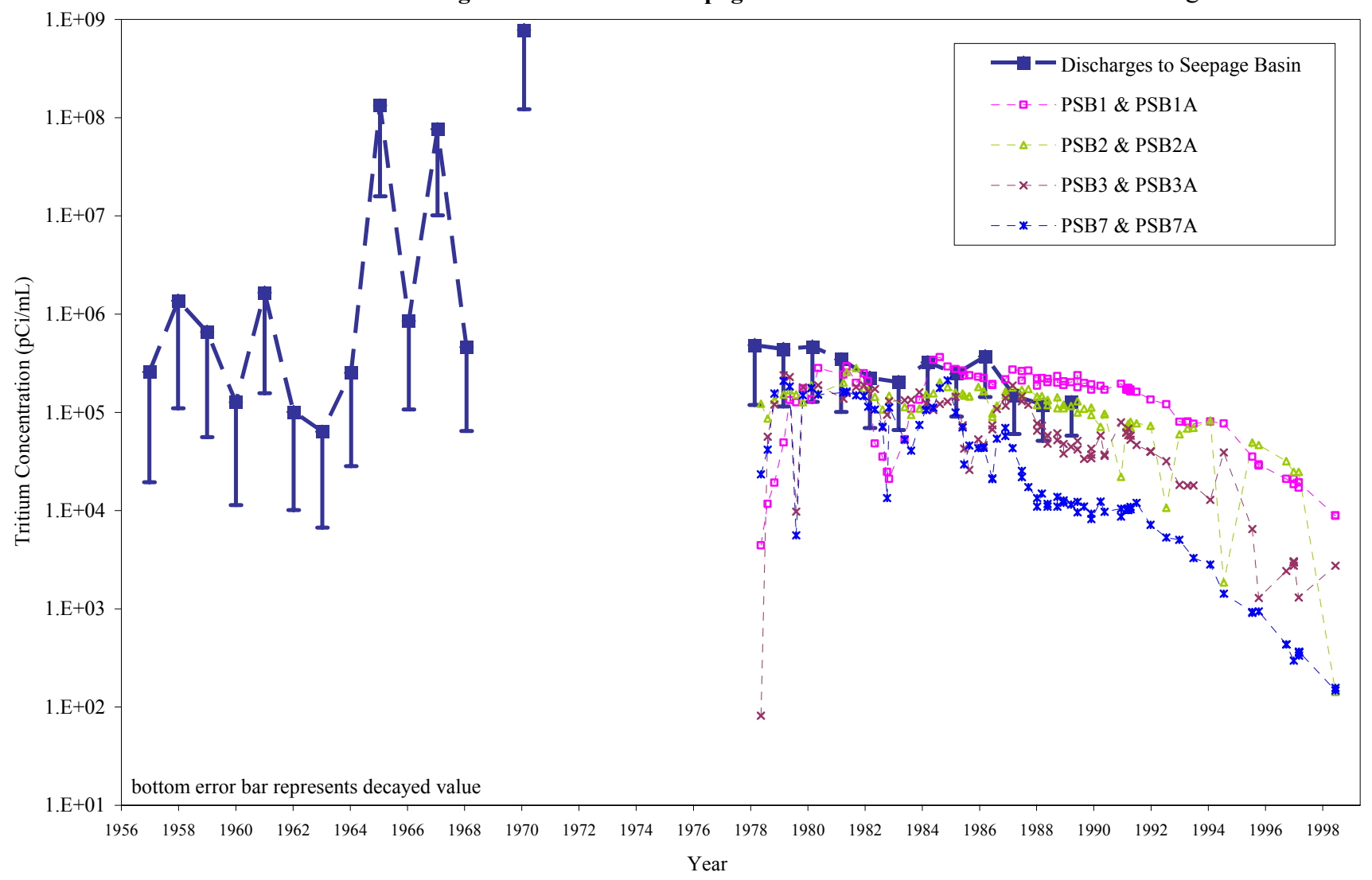

Figure 19 Tritium in Seepage Basins and PSB Wells 1978-1999

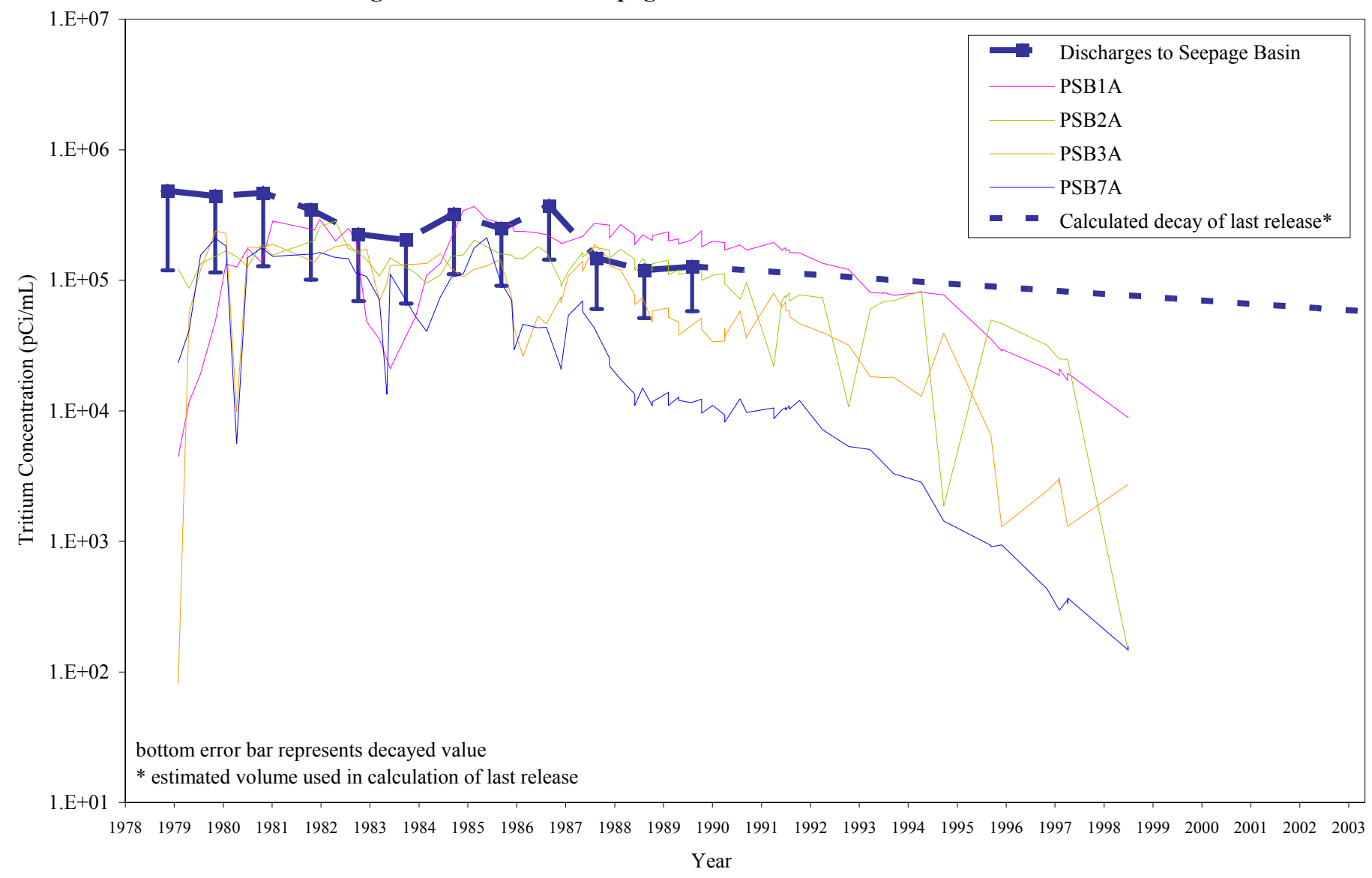


WSRC-TR-2003-00142

March 25, 2003

Page 31 of 49

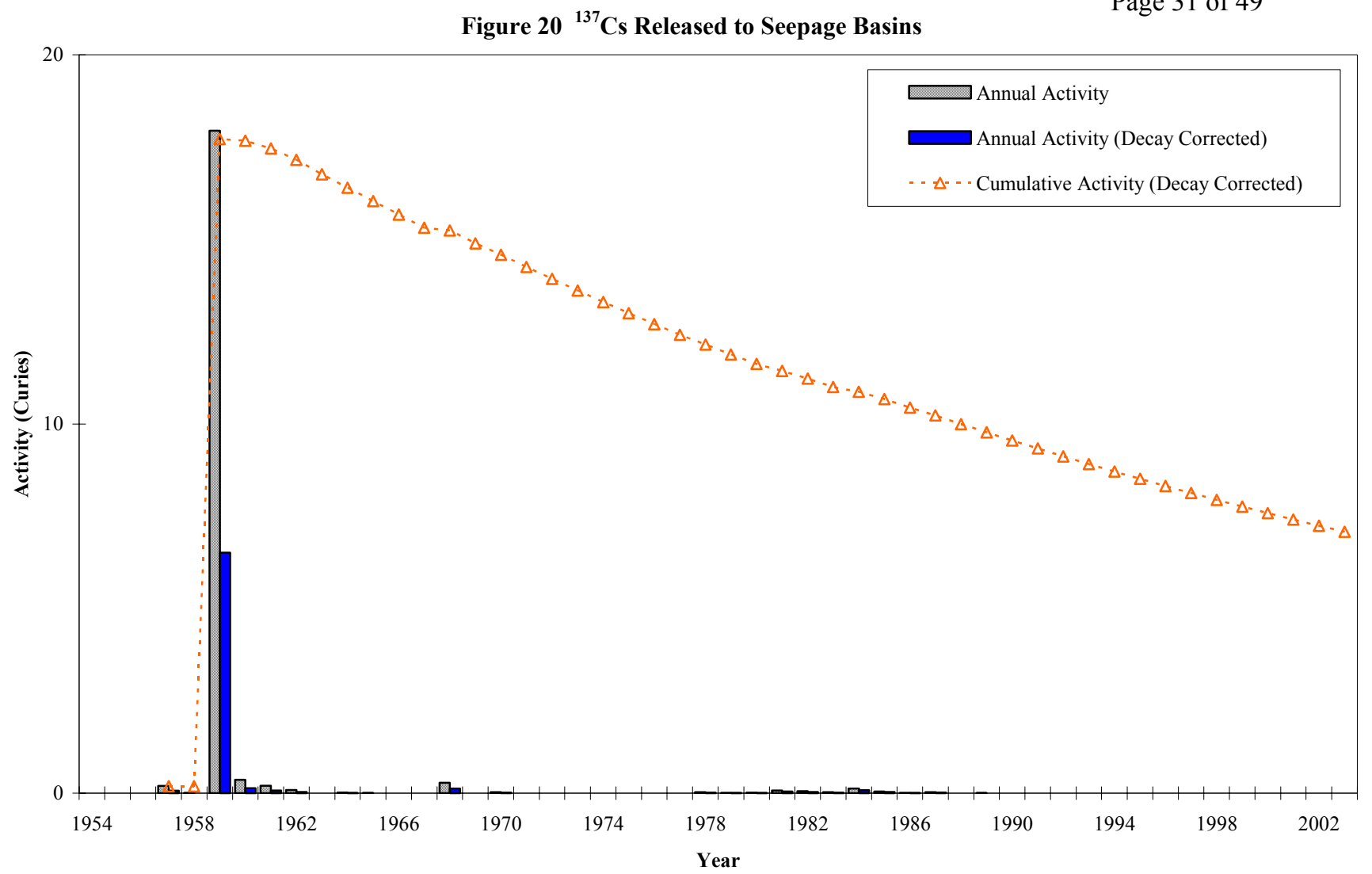

Figure $21{ }^{90} \mathrm{Sr}$ Released to Seepage Basins

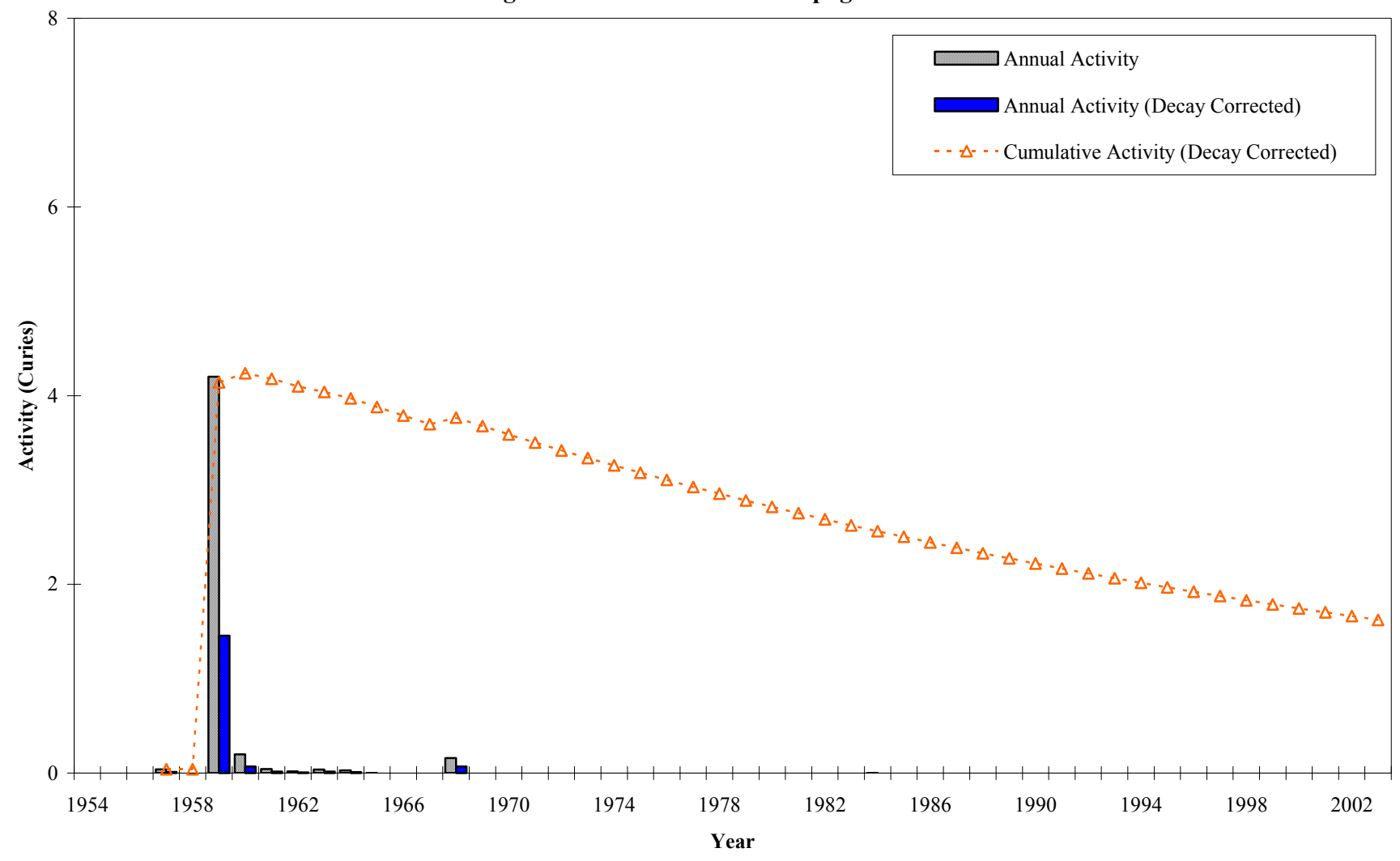


WSRC-TR-2003-00142

March 25, 2003

Page 32 of 49

Appendix A Documents Reviewed (from Unclassified and Classified Searches)

\begin{tabular}{|c|c|c|c|c|}
\hline Object Name & Title & Bin Num/Date & $\begin{array}{c}\text { Box Num or } \\
\text { Author } \\
\end{array}$ & Subject \\
\hline 38343 & $\begin{array}{l}\text { IMPROVED FLUSHING FACILITIES - C,K, } \\
\text { AND P AREAS - PROCESS SCOPE OF WORK }\end{array}$ & $\begin{array}{c}\text { *VARC/12/18/198 } \\
4 \text { 12:00:00 AM }\end{array}$ & RTGEWR149 & \\
\hline 100182 & $\begin{array}{l}\text { SITE CLEARANCE FOR 300M GALLON } \\
\text { TANK WITH DRAIN LINE AND ELECTRIC } \\
\text { FACILITIES - IMPROVED REACTOR } \\
\text { CONFINEMENT FACILITY - P AREA }\end{array}$ & *VARC & RTGEWR97 & \\
\hline 105167 & $\begin{array}{c}\text { REACTOR ROOM FLOOR DRAIN } \\
\text { CALCULATION - P AREA }\end{array}$ & *VARC & RTGSG12 & \\
\hline 401738 & $\begin{array}{l}\text { DISASSEMBLE WATER RECIRCULATION; P } \\
\text { AREA; AUXILIARIES BLDGS.; OME PLAN; } \\
\text { FILTER CUBICLES; TRENCH; BACKWASH } \\
\text { PIT; HEAT EXCHANGE SUPPORT }\end{array}$ & *VARC & RTGCALC60 & \\
\hline 401764 & $\begin{array}{l}\text { OUTSIDE ISOLATION TANK; P AREA; } \\
\text { O.M.E.; DISASSEMBLY AREA }\end{array}$ & 7/14/1959 0:00 & $\begin{array}{l}\text { CORNWELL,JA, } \\
\text { THURMAN,HR }\end{array}$ & $\begin{array}{c}\text { BAYS, DOORS, CRANES, PRESSURE, } \\
\text { BASINS, CASKS, SLABS, BASES, } \\
\text { HYDROSTATICS, WALLS, TANKS, } \\
\text { CALCULATIONS }\end{array}$ \\
\hline 401766 & $\begin{array}{c}\text { HEAT EXCHANGER STUDY; R AREA; P } \\
\text { AREA }\end{array}$ & *VARC & RTGCALC60 & \\
\hline 401782 & $\begin{array}{c}\text { FAILED REACTOR; P AREA; CROSS } \\
\text { SECTION OF LIFT }\end{array}$ & *VARC & RTGCALC60 & \\
\hline 401799 & $\begin{array}{c}\text { RAILROAD CAR CASK SHIELD TANK; P } \\
\text { AREA }\end{array}$ & $1 / 27 / 19600: 00$ & SIMPSON,CW & $\begin{array}{l}\text { PLATES, SHIELDS, TANKS, CASKS, } \\
\text { CALCULATIONS }\end{array}$ \\
\hline 401918 & $\begin{array}{c}\text { SEISMIC BRACING; HEAT EXCHANGER; P } \\
\text { AREA }\end{array}$ & $\begin{array}{c}\text { *VARC/4/3/1969 } \\
12: 00: 00 \mathrm{AM}\end{array}$ & RTGCALC66 & \\
\hline 401990 & $\begin{array}{r}\text { COLLAPSING PRESSURES OF MAIN TANK; } \\
\text { R AREA; P AREA; L AREA; K AREA; C AREA; } \\
\text { REACTOR; OPERATION FATSO; ED-2341; } \\
\text { DPE-772 } \\
\end{array}$ & *VARC & RTGCALC70 & \\
\hline 401992 & $\begin{array}{l}\text { 100-P AREA MODIFICATIONS TO COOLING } \\
\text { WATER SUPPLY; POWER; PAR POND }\end{array}$ & 9/6/1961 0:00 & $\begin{array}{l}\text { DEFRATE,LA, } \\
\text { SCHWALM,JM, } \\
\text { HUNT,FL }\end{array}$ & $\begin{array}{l}\text { PAR POND, FLUID FLOW, COOLING } \\
\text { WATER, POWER, CALCULATIONS }\end{array}$ \\
\hline 402124 & $\begin{array}{c}\text { SEISMIC PROTECTION; REACTOR } \\
\text { BUILDING; P AREA; K AREA; C AREA; } \\
\text { FINAL REPORT; JOHN A. BLUME AND } \\
\text { ASSOCIATES } \\
\end{array}$ & $\begin{array}{c}\text { *VARC/7/22/1977 } \\
\text { 12:00:00 AM }\end{array}$ & RTGCALC79 & \\
\hline 540000012 & $\begin{array}{c}\text { SPECIAL HAZARDS INCIDENT } \\
\text { INVESTIGATION CLASS I REACTOR } \\
\text { DEPARTMENT EMPLOYEES 100-P AREA (U) }\end{array}$ & & & \\
\hline 540000013 & $\begin{array}{c}\text { SPECIAL HAZARDS INCIDENT } \\
\text { INVESTIGATION CLASS I MAINTENANCE } \\
\text { DEPARTMENT EMPLOYEES } 100 \text { P-AREA (U) }\end{array}$ & $3 / 18 / 19540: 00$ & SRP & $\begin{array}{l}\text { EXPOSURES, P-AREA, SPECIAL } \\
\text { HAZARDS INVESTIGATION }\end{array}$ \\
\hline 540000027 & $\begin{array}{l}\text { UNUSUAL INCIDENT MODERATOR SPILL } \\
\text { IN D CELL SUMP 100-P DECEMBER } 141954 \\
\text { (U) }\end{array}$ & 12/14/1954 0:00 & $\begin{array}{l}\text { EGGERT,J, } \\
\text { GALLOWAY,L }\end{array}$ & $\begin{array}{l}\text { PURIFICATION, P-AREA, MODERATORS, } \\
\text { INCIDENTS, UNUSUAL INCIDENTS }\end{array}$ \\
\hline 540000523 & $\begin{array}{c}\text { PRODUCTION AND JOINT PROBLEMS R } \\
\text { AND P AREAS (U) }\end{array}$ & 5/1/1954 0:00 & KUGLER,FS & CORRESPONDENCE \\
\hline 540001892 & $\begin{array}{l}\text { ADAPTER REMOVAL-DISASSEMBLY AREA } \\
\text { P AREA (U) }\end{array}$ & $3 / 26 / 19540: 00$ & BOSWELL,JM & AREAS, CORRESPONDENCE \\
\hline 550000002 & $\begin{array}{l}100 \text { AREA METALLURGICAL REPORTS } \\
\text { COMPLIATION (U) }\end{array}$ & 1/18/1955 0:00 & SMITH,WE & $\begin{array}{l}\text { K-AREA, R-AREA, L-AREA, P-AREA, } \\
\text { REACTORS, EQUIPMENT, } \\
\text { METALLURGICAL REPORTS, 100-AREA }\end{array}$ \\
\hline 550000027 & $\begin{array}{c}\text { SEPTIFOIL FLOW RATES WITH HOT } \\
\text { COOLANT SUPPLY R AND P AREAS (U) }\end{array}$ & $5 / 13 / 19550: 00$ & LEYSE,RH & $\begin{array}{c}\text { P-AREA, R-AREA, COOLANTS, FLOW } \\
\text { RATE, SEPTIFOILS }\end{array}$ \\
\hline 560001671 & $\begin{array}{c}\text { MODERATOR PROCESSING FACILITY-P } \\
\text { AREA (U) }\end{array}$ & & & \\
\hline 560001705 & 100-P AREA PROCESS WATER LEAK (U) & & & \\
\hline 560002744 & FUEL SLUG 100-P AREA (U) & $3 / 15 / 19560: 00$ & MOUSEL,RM & CORRESPONDENCE \\
\hline 560002782 & FUEL INSPECTION IN P AREA SLUGS (U) & $3 / 15 / 19560: 00$ & MOUSEL,RM & CORRESPONDENCE \\
\hline
\end{tabular}


WSRC-TR-2003-00142

March 25, 2003

Page 33 of 49

Appendix A Documents Reviewed (from Unclassified and Classified Searches) (continued)

\begin{tabular}{|c|c|c|c|c|}
\hline Object Name & Title & Bin Num/Date & $\begin{array}{l}\text { Box Num or } \\
\text { Author }\end{array}$ & Subject \\
\hline 570000107 & $\begin{array}{c}\text { 100-P AREA REPAIR ORDER LIST } \\
\text { INCOMPLETE AFTER THREE MONTHS OR } \\
\text { MORE }\end{array}$ & 8/10/1957 0:00 & $\begin{array}{l}\text { SELKIRK,RH } \\
\text { RHODES,SC }\end{array}$ & $\begin{array}{c}\text { REPAIR, MAINTENANCE, } \\
\text { INSTRUMENTS, ELECTRICITY, P-AREA }\end{array}$ \\
\hline 570001829 & $\begin{array}{l}\text { P AREA DISASSEMBLY BASIN WATER AND } \\
\text { STEEL CREEK EFFLUENT (U) } \\
\end{array}$ & *VARC & M419-11584-4 & \\
\hline 580000951 & HIGH LEVEL WASTE STORAGE SHED & 10/7/1958 0:00 & MCCLEAREN,HA & P-AREA, R-AREA, WASTES, STORAGE \\
\hline 600001778 & \begin{tabular}{|c|} 
P AREA HEAT EXCHANGER \\
\end{tabular} & & & \\
\hline 610001351 & $\begin{array}{c}\text { PRELIMINARY REPORT P AREA PROCESS } \\
\text { INCIDENT P-79 PROCESS WATER SPILL IN - } \\
20 \text { HEAT EXCHANGER BAY }\end{array}$ & & & \\
\hline 610001357 & $\begin{array}{l}\text { SRP REACTOR DEPARTMENT PROCESS } \\
\text { INCIDENT C-63 TILTED HORIZONTAL } \\
\text { STORAGE RACK CONTAINING BUNDLES } \\
\text { OF MARK-6J FUEL ELEMENTSBLD-105C }\end{array}$ & & & \\
\hline 750000324 & $\begin{array}{c}\text { FUEL PREP AREA RADIOACTIVE RELEASES } \\
\text { ATMOSPHRC\& LIQUID"MO TO ERDA BY C } \\
\text { M PATTERSON" }\end{array}$ & & & \\
\hline 800000192 & $\begin{array}{c}\text { RESPONSE TO PROJECT REVIEW-P AREA- } \\
\text { IMPROVED CONFINEMENT OF } \\
\text { RADIOACTIVERELEASES(S1745)- } \\
\text { IMPROVED SUPPLY OF EMERGENCY } \\
\text { COOLANT(S1830) }\end{array}$ & & & \\
\hline 850000586 & $\begin{array}{c}\text { REACTOR INCIDENT STATUS - P AREA } \\
\text { JANUARY-FEBRURARY, } 1985\end{array}$ & & & \\
\hline 850002611 & $\begin{array}{c}\text { REACTOR INCIDENT STATUS - P AREA } \\
\text { JULY } 1985 \text { - AUGUST } 1985 \\
\end{array}$ & & & \\
\hline $138956-11$ & $\begin{array}{c}\text { DCF } 11 \text { - SPILL CONTAINMENT - 100P AREA } \\
\text { POWER AND ENVIRONMENTAL } \\
\text { PROTECTION }\end{array}$ & *FILMDES & $\begin{array}{c}\text { FE5200-1836-95- } \\
290\end{array}$ & \\
\hline $138956-16$ & $\begin{array}{c}\text { DCF } 16 \text { - SPILL CONTAINMENT - 100P AREA } \\
\text { POWER AND ENVIRONMENTAL } \\
\text { PROTECTION }\end{array}$ & *FILMDES & $\begin{array}{c}\text { FE5200-1836-95- } \\
290\end{array}$ & \\
\hline $138956-19$ & $\begin{array}{c}\text { DCF } 19 \text { - SPILL CONTAINMENT - 100P AREA } \\
\text { POWER AND ENVIRONMENTAL } \\
\text { PROTECTION }\end{array}$ & *FILMDES & $\begin{array}{l}\text { FE5200-1836-95- } \\
290\end{array}$ & \\
\hline CORR-870085 & \begin{tabular}{c|} 
REACTOR MATERIALS PROGRAM SRP \\
REACTORS PROCESS WATER \\
PIPINGWATER HAMMER \\
\end{tabular} & & & \\
\hline DDR-12415 & $\begin{array}{l}100 \text { AREA - POWER HOUSE - BUILDINGS 184 } \\
\text { K, L, P, \& R - } 100 \text { AREA - COOLING TOWER - } \\
\text { BUILDINGS 185-K, L, P \& R - } 100 \text { AREA - ASH } \\
\text { DISPOSAL BASIN - BUILDINGS 188-K, L, P \& } \\
\text { R (U) } \\
\end{array}$ & $5 / 14 / 19520: 00$ & $\begin{array}{l}\text { MEASLEY,HF, } \\
\text { DAUDT,LR }\end{array}$ & $\begin{array}{l}\text { DESIGN DATA REPORTS, R-AREA, L- } \\
\text { AREA, P-AREA, K-AREA }\end{array}$ \\
\hline DPE-0971-VOL2 & $\begin{array}{c}\text { SAVANNAH RIVER PLANT ENGINEERING } \\
\text { DESIGN HISTORY - VOLUME } 2 \text { - PROJECT } \\
8980-100 \text { RPLKC AREAS }\end{array}$ & 1/1/1957 0:00 & & $\begin{array}{l}\text { C-AREA, P-AREA, L-AREA, K-AREA, R- } \\
\text { AREA, SAVANNAH RIVER PLANT, } \\
\text { ENGINEERING, DESIGN HISTORY }\end{array}$ \\
\hline DPSOP-22-HIST-VOL1 & $\begin{array}{c}\text { OPERATING PROCEDURE FOR } 100-\mathrm{R} \& \mathrm{P} \\
\text { AREA ENGINE HOUSES }(3 / 53-6 / 58)\end{array}$ & $6 / 30 / 19580: 00$ & & $\begin{array}{c}\text { PROCEDURES, P-AREA, R-AREA, 100- } \\
\text { AREA } \\
\end{array}$ \\
\hline DPSOX-00582 & ELIMINATION OF FLOW ZONE III P AREA & 8/20/1954 0:00 & WINGERD,DH & MONITORS, ZONES, TEST CONCLUSION \\
\hline DPSOX-01125 & $\begin{array}{c}\text { PROCESS WATER GAMMA AND } \\
\text { TEMPERATURE MONITORS P AREA }\end{array}$ & & & \\
\hline DPSP-54-0025-023 & MODERATOR CHARGING - P AREA & 7/21/1954 0:00 & REYNOLDS,HE & AREA, MODERATORS \\
\hline DPSP-54-0046-001 & $\begin{array}{c}\text { INVENTORY AND CONSUMPTION REPORT } \\
\text { 100-P PRODUCER ALLOY-3.5\% LITHIUM } \\
\text { FEBRUARY, } 1954\end{array}$ & 2/1/1954 0:00 & & LITHIUM, ALLOYS, P-AREA, REPORTS \\
\hline DPSP-54-0046-002 & $\begin{array}{l}\text { INVENTORY AND CONSUMPTION REPORT } \\
\text { 100-P FUEL SLUGS-NORMAL URANIUM } \\
\text { MARCH , } 1954\end{array}$ & 3/1/1954 0:00 & & URANIUM, P-AREA, REPORTS \\
\hline DPSP-54-0046-004 & $\begin{array}{c}\text { INVENTORY AND CONSUMPTION REPORT } \\
\text { 100-P PRODUCER ALLOY-3.5\% LITHIUM, } \\
\text { MAY1954 }\end{array}$ & $5 / 1 / 19540: 00$ & & LITHIUM, ALLOYS, P-AREA, REPORTS \\
\hline DPSP-54-0046-006 & $\begin{array}{l}\text { INVENTORY AND CONSUMPTION REPORT } \\
\text { 100-P FUEL SLUGS-NORMAL URANIUM, } \\
\text { JULY, } 1954\end{array}$ & 7/1/1954 0:00 & & URANIUM, P-AREA, REPORTS \\
\hline DPSP-54-0541 & $\begin{array}{l}\text { ASSEMBLY SLUG HANDLING STUDY 100-P } \\
\text { AREA }\end{array}$ & 9/19/1954 0:00 & CROLEY,JJJR & SLUGS \\
\hline
\end{tabular}


WSRC-TR-2003-00142

March 25, 2003

Page 34 of 49

Appendix A Documents Reviewed (from Unclassified and Classified Searches) (continued)

\begin{tabular}{|c|c|c|c|c|}
\hline Object Name & Title & Bin Num/Date & $\begin{array}{c}\text { Box Num or } \\
\text { Author } \\
\end{array}$ & Subject \\
\hline DPSP-56-0601 & $\begin{array}{c}\text { MODERATOR DILUTION AND } \\
\text { DISTILLATION EFFICIENCY - P AREA }\end{array}$ & & & \\
\hline DPSP-56-1199 & REACTOR CHARGES P AREA & & & \\
\hline DPSP-57-0943 & $\begin{array}{c}\text { PROCESS INCIDENT NO P3 } 105 \text { P AREA } \\
\text { FUEL ELEMENT FAILURE IN MARK } 1 \text { SLUG } \\
\text { ON JUNE } 201957\end{array}$ & & & \\
\hline DPSP-57-1005 & $\begin{array}{c}\text { PROCESS INCIDENT NO } 105 \text { P AREA FUEL } \\
\text { ELEMENT FAILURE IN MARK1 SLUG ON } \\
\text { JULY } 151957\end{array}$ & & & \\
\hline DPSP-58-0196-P-14-15 & DAILY SHIFT REPORT & 1/1/1958 0:00 & & P-AREA, SHUTDOWNS \\
\hline DPSP-58-1678 & $\begin{array}{c}\text { ACTIVITY OF PAR POND WATER BEING } \\
\text { PUMPED TO R AND P AREAS }\end{array}$ & 10/27/1958 0:00 & MCCLEAREN,HA & PAR POND \\
\hline DPSP-59-0972 & $\begin{array}{c}\text { TEMPORARY PROCEDURE UNDER TA 1-747 } \\
\text { 100-R AND P AREAS - ASSEMBLY AND } \\
\text { DISASSEMBLY AREAS } \\
\end{array}$ & $5 / 11 / 19590: 00$ & GRIER,BH & REACTORS \\
\hline DPSP-59-1452 & FUEL ELEMENT FAILURE P AREA & 8/7/19590:00 & BRYAN,SE & REACTORS \\
\hline DPSP-59-1803 & \begin{tabular}{|c|} 
PRELIMINARY INSPECTION REPORT \\
VISUAL INSPECTION OF FAILURE NUMBER \\
73100 P AREA \\
\end{tabular} & 11/10/1959 0:00 & MOUSEL,RM & REACTORS \\
\hline DPSP-61-1005 & \begin{tabular}{|c|} 
MARK VI-JL REACTOR CHARGE \\
SPECIFICATIONS - L AND P AREAS \\
\end{tabular} & & & \\
\hline DPSP-61-1816 & $\begin{array}{c}\text { INVENTORY AND CONSUMPTON REPORT } \\
\text { COBALT } 60 \text { 100-P AREA } \\
\end{array}$ & 6/1/1961 0:00 & $\begin{array}{l}\text { SMOLAND,HT } \\
\text { BLITHE,WL }\end{array}$ & P-AREA \\
\hline DPSPF-02436 & PROCESS PIPING, P AREA (photography) & & & \\
\hline DPSPF-35060 & $\begin{array}{l}\text { 10C P AREA PROCESS WATER PIPING } \\
\text { (photography) }\end{array}$ & & & \\
\hline DPSPU-56-011-029 & HEAT EXCHANGER FAILURE P AREA (U) & *COMBINED & M419-8322-1 & \\
\hline DPST-55-00322 & $\begin{array}{c}\text { SEPARATION OF ACTIVITY FROM BLD- } \\
\text { 105P MODERATOR WATER BY } \\
\text { CENTRUFUGATION - TEST RESULTS. }\end{array}$ & 7/12/1955 0:00 & VAUX,JE & $\begin{array}{c}\text { TABLES, CENTRIFUGES, P-AREA, } \\
\text { DECONTAMINATION, RADIOACTIVITY, } \\
\text { PURIFICATION, CHEMISTRY, } \\
\text { MODERATORS, OPERATION, } \\
\text { REACTORS } \\
\end{array}$ \\
\hline DPST-57-00193 & $\begin{array}{l}\text { ANALYSIS OF SPENT ION EXCHANGE } \\
\text { DEIONIZER RESIN FROM BLD-105P. }\end{array}$ & 3/28/1957 0:00 & BAUMANN,EW & $\begin{array}{c}\text { TABLES, CATIONS, ANIONS, SLUDGES, } \\
\text { CONTAMINATION, SERVICE, } \\
\text { EQUIPMENT, P-AREA, RESINS, IONS, } \\
\text { ANALYSIS, OPERATION, REACTORS }\end{array}$ \\
\hline DPST-80-00323 & $\begin{array}{c}\text { RESPONSE OF ABS/SC TO ROD } \\
\text { WITHDRAWAL ACCIDENTS IN SRP } \\
\text { REACTORS. } \\
\end{array}$ & N61-05-04 & $\begin{array}{l}\text { L1000-0307-92- } \\
\quad 402\end{array}$ & \\
\hline DPST-80-00618 & $\begin{array}{c}\text { CONTAINMENT \& RECIRCULATION OF } \\
\text { SPILLED WATER IN SRP } \\
\text { REACTORBUILDINGS. } \\
\end{array}$ & & & \\
\hline DPST-81-00626 & $\begin{array}{c}\text { GENERIC STUDY OF ABS/SC RESPONSES } \\
\text { FOR MARK-22 CHARGES IN SRP } \\
\text { REACTORS. } \\
\end{array}$ & & & \\
\hline DPST-82-00284 & SRP REACTOR RISKS. & & & \\
\hline DPST-85-00717 & $\begin{array}{l}\text { TWO-PHASE NATURAL CIRCULATION IN } \\
\text { SRP REACTORS - (AFTER PUMPSTOPPAGE). }\end{array}$ & & & \\
\hline DPTT-70-7-17 & DAILY REPORT - PART ONE REACTORS & & & \\
\hline DPTT-70-7-17A & DAILY REPORT - PART ONE A REACTORS & & & \\
\hline DPTT-70-7-22 & DAILY REPORT - PART ONE REACTORS & & & \\
\hline DPTT-70-7-23 & DAILY REPORT - PART ONE REACTORS & & & \\
\hline DPTT-70-7-27-A & DAILY REPORT - PART ONE A REACTORS & & & \\
\hline DPTT-70-8-18 & DAILY REPORT - PART ONE REACTORS & & & \\
\hline DPTT-70-8-20 & DAILY REPORT - PART ONE REACTORS & & & \\
\hline DPTT-70-8-24 & DAILY REPORT - PART ONE REACTORS & & & \\
\hline DPTT-70-8-25 & DAILY REPORT - PART ONE REACTORS & & & \\
\hline DPTT-70-8-4 & DAILY REPORT - PART ONE REACTORS & & & \\
\hline DPTT-70-8-5 & DAILY REPORT - PART ONE REACTORS & & & \\
\hline DPTT-70-9-10 & DAILY REPORT - PART ONE REACTORS & & & \\
\hline DPTT-71-12-20 & DAILY REPORT - PART ONE REACTORS & & & \\
\hline DPTT-71-12-20A & DAILY REPORT - PART ONE A REACTORS & & & \\
\hline DPTT-71-12-21 & DAILY REPORT - PART ONE REACTORS & & & \\
\hline
\end{tabular}


WSRC-TR-2003-00142

March 25, 2003

Page 35 of 49

Appendix A Documents Reviewed (from Unclassified and Classified Searches) (continued)

\begin{tabular}{|c|c|c|c|c|}
\hline Object Name & Title & Bin Num/Date & $\begin{array}{l}\text { Box Num or } \\
\text { Author }\end{array}$ & Subject \\
\hline DPTT-71-12-21A & DAILY REPORT - PART ONE A REACTORS & & & \\
\hline DPTT-71-12-22 & DAILY REPORT - PART ONE REACTORS & & & \\
\hline DPTT-71-12-22-B & $\begin{array}{c}\text { WEEKLY PRODUCTION SUMMARY } \\
\text { REACTORS }\end{array}$ & & & \\
\hline DPTT-71-5-13A & DAILY REPORT - PART ONE A REACTORS & & & \\
\hline DPTT-71-6-14A & DAILY REPORT - PART ONE A REACTORS & & & \\
\hline DPTT-74-12-16A & DAILY REPORT - PART ONE A REACTORS & & & \\
\hline DPTT-74-12-17 & DAILY REPORT - PART ONE REACTORS & & & \\
\hline DPTT-74-12-17A & DAILY REPORT - PART ONE A REACTORS & & & \\
\hline DPTT-74-8-16 & DAILY REPORT - PART ONE REACTORS & & & \\
\hline DPTT-74-8-19 & DAILY REPORT - PART ONE REACTORS & & & \\
\hline DPTT-74-9-10 & DAILY REPORT - PART ONE REACTORS & & & \\
\hline DPTT-74-9-23 & DAILY REPORT - PART ONE REACTORS & & & \\
\hline DPTT-75-1-31 & DAILY REPORT - PART ONE REACTORS & & & \\
\hline DPTT-75-2-20 & DAILY REPORT - PART ONE REACTORS & & & \\
\hline DPTT-75-2-25 & DAILY REPORT - PART ONE REACTORS & & & \\
\hline DPTT-75-2-4 & DAILY REPORT - PART ONE REACTORS & & & \\
\hline DPTT-75-2-7C & $\begin{array}{c}\text { WEEKLY PRODUCTION SUMMARY } \\
\text { REACTORS } \\
\end{array}$ & & & \\
\hline DPTT-75-3-14A & DAILY REPORT - PART ONE A REACTORS & & & \\
\hline DPTT-75-4-23 & DAILY REPORT - PART ONE REACTORS & & & \\
\hline DPTT-75-4-30 & DAILY REPORT - PART ONE REACTORS & & & \\
\hline DPTT-75-5-27 & DAILY REPORT - PART ONE REACTORS & & & \\
\hline DPTT-75-8-13A & DAILY REPORT - PART ONE A REACTORS & & & \\
\hline DPTT-75-8-13A & DAILY REPORT - PART ONE REACTORS & & & \\
\hline DPTT-75-8-19 & DAILY REPORT - PART ONE REACTORS & & & \\
\hline DPTT-75-9-11 & DAILY REPORT - PART ONE REACTORS & & & \\
\hline DPTT- 8807 & DAILY REPORT - PART ONE REACTORS & & & \\
\hline DPTT-8835 & DAILY REPORT - PART ONE REACTORS & & & \\
\hline DPTT-8845 & DAILY REPORT - PART ONE REACTORS & & & \\
\hline DPTT-8846 & DAILY REPORT - PART ONE A REACTORS & & & \\
\hline DPTT-8853 & DAILY REPORT - PART ONE REACTORS & & & \\
\hline DPTT-8854 & DAILY REPORT - PART ONE A REACTORS & & & \\
\hline DPTT-8879 & DAILY REPORT - PART ONE REACTORS & & & \\
\hline DPTT-8941 & DAILY REPORT - PART ONE REACTORS & & & \\
\hline DPTT-8942 & DAILY REPORT - PART ONE A REACTORS & & & \\
\hline DPTT-9021 & DAILY REPORT - PART ONE A REACTORS & & & \\
\hline DPTT-9124 & DAILY REPORT - PART ONE REACTORS & & & \\
\hline DPTT-9156 & DAILY REPORT - PART ONE REACTORS & & & \\
\hline DPTT-9191 & DAILY REPORT - PART ONE REACTORS & & & \\
\hline DPTTWD-75-9-12-B & $\begin{array}{c}\text { WEEKLY PRODUCTION SUMMARY } \\
\text { REACTORS }\end{array}$ & & & \\
\hline PI-P-60-53 & $\begin{array}{c}\text { PROCESS INCIDENT NO P-53 NO } 6 \\
\text { BINGHAM PUMP SEAL FAILURE (U) } \\
\end{array}$ & $11 / 28 / 19590: 00$ & LIST,JA & $\begin{array}{c}\text { REACTORS, TANKS, PUMPS, LEAKS, P- } \\
\text { AREA, PROCESS INCIDENTS } \\
\end{array}$ \\
\hline PI-P-60-54 & $\begin{array}{l}\text { PROCESS INCIDENT NO P-54 PW SPILL } \\
\text { PARTIALLY FILLED DEIONIZER (U) }\end{array}$ & 2/6/1960 0:00 & LIST,JA & LEAKS, P-AREA, PROCESS INCIDENTS \\
\hline PI-P-60-55 & $\begin{array}{c}\text { PROCESS INCIDENT NO P-55 SPARJET } \\
\text { INSERT FAILURE (U) }\end{array}$ & 2/16/1960 0:00 & LIST,JA & $\begin{array}{l}\text { RINGS, FAILURES, P-AREA, PROCESS } \\
\text { INCIDENTS }\end{array}$ \\
\hline PI-P-60-57 & $\begin{array}{l}\text { PROCESS INCIDENT NO P-57-105P SEAL } \\
\text { FILTER HOUSING LEAKS (U) }\end{array}$ & $5 / 28 / 19600: 00$ & LIST,JA & $\begin{array}{c}\text { PUMPS, FILTERS, REACTORS, } \\
\text { SHUTDOWNS, LEAKS, P-AREA, } \\
\text { PROCESS INCIDENTS } \\
\end{array}$ \\
\hline PI-P-60-58 & $\begin{array}{l}\text { PROCESS INCIDENT NO P-58 105-P } \\
\text { INCOMPLETE DRAINING OF HEAT } \\
\text { EXCHANGERS (U) }\end{array}$ & 7/18/1960 0:00 & LIST,JA & $\begin{array}{l}\text { HEAT EXCHANGERS, P-AREA, PROCESS } \\
\text { INCIDENTS }\end{array}$ \\
\hline PI-P-60-59 & $\begin{array}{l}\text { PROCESS INCIDENT NO P-59 105-P MARK } \\
\text { VII-AL LOW P (U) }\end{array}$ & 7/19/1960 0:00 & LIST,JA & $\begin{array}{l}\text { SHUTDOWNS, REACTORS, P-AREA, } \\
\text { PROCESS INCIDENTS }\end{array}$ \\
\hline RI-P-0024 & EXCESSIVE SHUTDOWN FLOW & 10/21/1957 0:00 & $\begin{array}{l}\text { MCMANAWAY, } \\
\text { GW }\end{array}$ & P-AREA, REACTOR INCIDENTS \\
\hline RI-P-0119 & $\begin{array}{c}\text { TURBID MODERATOR PUMPED TO SURGE } \\
\text { TANK }\end{array}$ & 6/27/1959 0:00 & HINTON,JH & $\begin{array}{l}\text { REACTOR INCIDENTS, P-AREA, } \\
\text { MODERATORS }\end{array}$ \\
\hline RI-P-0120 & LOSS OF REACTOR OVERFLO & 7/14/1959 0:00 & HINTON,JH & P-AREA, REACTOR INCIDENTS \\
\hline RI-P-0127 & SEAL COOLER PW LEAK & $8 / 14 / 19590: 00$ & BOSWELL,JM & P-AREA, REACTOR INCIDENTS \\
\hline RI-P-0135 & PW LEAKS & $10 / 13 / 19590: 00$ & HINTON,JH & REACTOR INCIDENTS, P-AREA, LEAKS \\
\hline RI-P-0138 & PW LEAK VALVE $8 \mathrm{~J}$ & 10/19/1959 0:00 & HINTON,JH & $\begin{array}{c}\text { REACTOR INCIDENTS, P-AREA, } \\
\text { VALVES }\end{array}$ \\
\hline
\end{tabular}


WSRC-TR-2003-00142

March 25, 2003

Page 36 of 49

Appendix A Documents Reviewed (from Unclassified and Classified Searches) (continued)

\begin{tabular}{|c|c|c|c|c|}
\hline Object Name & Title & Bin Num/Date & $\begin{array}{l}\text { Box Num or } \\
\text { Author }\end{array}$ & Subject \\
\hline RI-P-0152 & NO 6 SYSTM SEAL LEAK & $11 / 30 / 19590: 00$ & HINTON,JH & P-AREA, REACTOR INCIDENTS, SEALS \\
\hline RI-P-0179 & CIC - EFFLUENT HEADER LEAK. & $5 / 18 / 19600: 00$ & VANNIEL,CR & $\begin{array}{l}\text { INFORMATION, PTERM, P-AREA, } \\
\text { INCIDENTS, UNUSUAL INCIDENTS, } \\
\text { PIPINGS, LEAKS, REPAIR, OPERATION, } \\
\text { REACTORS, WELDING }\end{array}$ \\
\hline RI-P-0188 & PW LEAK AT VALVE 84 & $6 / 22 / 19600: 00$ & HINTON,JH & REACTOR INCIDENTS, P-AREA, LEAKS \\
\hline RI-P-0192 & PW LEAK AT VALVE 85 & $6 / 23 / 19600: 00$ & HINTON,JH & REACTOR INCIDENTS, P-AREA, LEAKS \\
\hline RI-P-0193 & $\begin{array}{c}\text { SHUTDOWN FOR 3B HX TUBE SHEET } \\
\text { SPACE LEAK }\end{array}$ & $6 / 29 / 19600: 00$ & VANNIEL,CR & $\begin{array}{c}\text { P-AREA, REACTOR INCIDENTS, } \\
\text { SHUTDOWNS }\end{array}$ \\
\hline RI-P-0195 & PROCESS WATER SPILL & 6/30/1960 0:00 & VANNIEL,CR & P-AREA, REACTOR INCIDENTS, WATER \\
\hline RI-P-0203 & EXCESS REACTOR OVERFLOW & 9/6/1960 0:00 & HINTON,JH & REACTOR INCIDENTS, P-AREA \\
\hline RI-P-0268 & PW SPILL C-MACHINE & 11/14/1961 0:00 & HINTON,JH & REACTOR INCIDENTS, P-AREA, SPILLS \\
\hline RI-P-0269 & CW HEADER LEAKS & 11/16/1961 0:00 & VANNIEL,CR & REACTOR INCIDENTS, P-AREA, LEAKS \\
\hline RI-P-0271 & HX 4A STAYBOLT LEAK & 12/17/1961 0:00 & VANNIEL,CR & P-AREA, REACTOR INCIDENTS \\
\hline RRD-RED-92-0152 & $\begin{array}{c}\text { CURRENT HEAT EXCHANGER HEAD } \\
\text { STATUS IN P AREA (U) }\end{array}$ & & & \\
\hline RTM-00393 & $\begin{array}{l}\text { FAILURE OF DRAIN TANK PUMP IN 100-P } \\
\text { AREA }\end{array}$ & $3 / 26 / 19540: 00$ & JOHNSON,AA & RINGS, SEALS, PUMPS, REACTORS \\
\hline RTM-00604 & $\begin{array}{l}\text { DISASSEMBLY AREA CORROSION TESTS P } \\
\text { AREA }\end{array}$ & 11/8/1954 0:00 & GRIER,JD & $\begin{array}{c}\text { EQUIPMENT, REACTORS, EQUIPMENT, } \\
\text { REACTORS }\end{array}$ \\
\hline RTM-01261 & REPAIR PROCESS WTR VALV 86 -P AREA & & & \\
\hline RTM-01432 & $\begin{array}{l}\text { REDUCTION OF RADIOACTIVITY IN R AND } \\
\text { P AREAS }\end{array}$ & 9/27/1957 0:00 & FOX,LW & $\begin{array}{l}\text { SCHEDULES, PLANS, PROGRAMS, } \\
\text { REACTORS, MONITORING, SURVEYS }\end{array}$ \\
\hline RTM-01531 & $\begin{array}{c}\text { HYDRAULIC TESTS WITH BINGHAM } \\
\text { PUMPS P AREA } \\
\end{array}$ & 2/13/1958 0:00 & $\begin{array}{l}\text { INGHAM,RR, } \\
\text { GIMMY,KL }\end{array}$ & RINGS, SEALS, PUMPS, REACTORS \\
\hline RTM-01673 & $\begin{array}{c}\text { PROCESS WTR GAMMA MONITOR LINE } \\
\text { BRACE \#1 SYSTM -P AREA }\end{array}$ & & & \\
\hline RTM-01731 & LIGHT WATER INLEAKAGE - P AREA & 2/18/1959 0:00 & $\begin{array}{c}\text { HINTON,JH } \\
\text { JOHNSON,AA }\end{array}$ & REACTORS, P-AREA, LEAKAGE, WATER \\
\hline RTM-02059 & $\begin{array}{l}\text { TOP AND BOTTOM SHIELD LEAK P-AREA } \\
\text { (U) }\end{array}$ & 11/10/1960 0:00 & HINTON,JH & $\begin{array}{c}\text { FLOW RATE, PRESSURE, WATER, } \\
\text { MODERATORS, SHIELDS, LEAKS, P- } \\
\text { AREA, REACTOR TECHNOLOGY } \\
\text { MEMORANDUM }\end{array}$ \\
\hline RTM-0321 & $\begin{array}{c}\text { CHARGE AND DISCHARGE FLOWS - } 100 \\
\text { AREAS (U) }\end{array}$ & $1 / 21 / 19540: 00$ & BUTTON,DL & R-AREA, P-AREA \\
\hline RTM-0393 & $\begin{array}{l}\text { FAILURE OF DRAIN TANK PUMP IN } 100 \text { P } \\
\text { AREA (U) }\end{array}$ & $3 / 26 / 19540: 00$ & JOHNSON,AA & DRAINS \\
\hline RTM-0604 & $\begin{array}{c}\text { DISASSEMBLY AREA CORROSION TESTS } \\
(\mathrm{U})\end{array}$ & 11/8/1954 0:00 & JOHNSON,AA & P-AREA, CORROSION \\
\hline RTM-0850 & COOLING WATER GAMMA MONITORS (U) & $8 / 25 / 19550: 00$ & JOHNSON,AA & P-AREA, R-AREA, MONITORS \\
\hline RTM-0971 & $\begin{array}{c}\text { COOLING WATER GAMMA MONITOR } \\
\text { OPERATION (U) }\end{array}$ & 4/3/1956 0:00 & $\begin{array}{c}\text { JOHNSON,AA;ER } \\
\text { NST,ML }\end{array}$ & $\begin{array}{c}\text { C-AREA, K-AREA, L-AREA, P-AREA, R- } \\
\text { AREA, COOLING WATER }\end{array}$ \\
\hline SRL-USA-90-0110 & $\begin{array}{c}\text { POSSIBLE PROCESS WATER PIPING } \\
\text { DEGRADATION IN K AND P AREAS (U) }\end{array}$ & & & \\
\hline UI-P-012 & $\begin{array}{c}\text { SRP POWER DEPARTMENT UNUSUAL } \\
\text { INCIDENT REPORT 100-P AREA REPORT NO } \\
\text { P-12 (U) }\end{array}$ & & & \\
\hline UI-P-012 & $\begin{array}{c}\text { SRP POWER DEPARTMENT UNUSUAL } \\
\text { INCIDENT REPORT 100-P AREA REPORT NO } \\
\text { P-12 (U) }\end{array}$ & $11 / 29 / 19550: 00$ & SRP & $\begin{array}{l}\text { STEAM, POWER, TANKS, BURNS, } \\
\text { INCIDENTS, UNUSUAL INCIDENTS }\end{array}$ \\
\hline UI-P-105 & $\begin{array}{l}\text { UNUSUAL INCIDENT 105-P SEAL FAILURE } \\
\text { ON \#1 B-J PUMP (U) }\end{array}$ & 3/9/1955 0:00 & GALLOWAY,L & $\begin{array}{c}\text { UNUSUAL INCIDENTS, POWER, PUMPS, } \\
\text { MOTORS }\end{array}$ \\
\hline WSRC-FM-94-1481 & $\begin{array}{c}\text { 26C DISASSEMBLY BASIN SAMPLING 105-R } \\
\text { P AREA INSTRUMENT AIR DRYERS TANK D } \\
\text { AND D R AREA (U) (photography) }\end{array}$ & & & \\
\hline WSRC-TR-94-00403 & $\begin{array}{l}\text { CRITICALITY SAFETY EVALUATION FOR P } \\
\text { AREA DISASSEMBLY BASIN CLEANUP (U) }\end{array}$ & & & \\
\hline
\end{tabular}


WSRC-TR-2003-00142

March 25, 2003

Page 37 of 49

Appendix B Examples of Events in P Area Disassembly Basin History

\begin{tabular}{|c|c|c|c|c|c|c|}
\hline \multicolumn{7}{|c|}{ Examples of Events in Disassembly Basin History } \\
\hline \multirow[b]{2}{*}{ Date } & \multirow[b]{2}{*}{ Subject $^{1}$} & \multirow[b]{2}{*}{ Source } & \multirow[b]{2}{*}{ Disassembly Basin values } & \multicolumn{3}{|c|}{ reactor weir release $(\mathrm{Ci})$} \\
\hline & & & & ${ }^{89,90} \mathrm{Sr}$ & ${ }^{137} \mathrm{Cs}$ & ${ }^{3} \mathbf{H}$ \\
\hline Mar-1959 & $\begin{array}{l}\text { reactor discharge failed fuel } \\
\text { element }\end{array}$ & $\begin{array}{l}\text { Health Physics Regional } \\
\text { Monitoring, Weekly Report -- } \\
\text { Control }\end{array}$ & see note ${ }^{2}$ & NR & NR & NR \\
\hline Apr-1959 & $\begin{array}{l}\text { reactor discharge failed fuel } \\
\text { element }\end{array}$ & $\begin{array}{l}\text { Health Physics Regional } \\
\text { Monitoring, Weekly Report -- } \\
\text { Control }\end{array}$ & see note ${ }^{3}$ & NR & NR & NR \\
\hline $\begin{array}{l}\text { July-1959 } \\
\text { through Dec- } \\
1959\end{array}$ & $\begin{array}{l}\text { reactor discharges of two } \\
\text { failed fuel element; } \\
\text { handling of Chalk River } \\
\text { fuel elements }\end{array}$ & $\begin{array}{l}\text { Health Physics Regional Monitoring } \\
\text { Semiannual Report July through } \\
\text { December } 1959\end{array}$ & see note ${ }^{4}$ & & & \\
\hline Aug-1961 & $\begin{array}{l}\text { reactor discharge Mark } \\
\text { VIIA fuel element }\end{array}$ & $\begin{array}{l}\text { Health Physics Regional } \\
\text { Monitoring, Weekly Report -- } \\
\text { Control }\end{array}$ & see note ${ }^{5}$ & NR & NR & NR \\
\hline Oct-1961 & $\begin{array}{l}\text { reactor discharge Mark } \\
\text { VIIA fuel element }\end{array}$ & $\begin{array}{l}\text { Health Physics Regional } \\
\text { Monitoring, Weekly Report -- } \\
\text { Control }\end{array}$ & see note ${ }^{5}$ & NR & NR & NR \\
\hline Nov-1961 & $\begin{array}{l}\text { reactor discharge Mark } \\
\text { VIIA fuel element }\end{array}$ & $\begin{array}{l}\text { Health Physics Regional } \\
\text { Monitoring, Weekly Report -- } \\
\text { Control }\end{array}$ & see note ${ }^{5}$ & NR & NR & NR \\
\hline Jan-1962 & $\begin{array}{l}\text { reactor discharge Mark } \\
\text { VIIA fuel element }\end{array}$ & $\begin{array}{l}\text { Health Physics Regional } \\
\text { Monitoring, Weekly Report -- } \\
\text { Control }\end{array}$ & see note ${ }^{5}$ & NR & NR & NR \\
\hline Apr-1962 & $\begin{array}{l}\text { reactor discharge Mark } \\
\text { VIIA fuel element }\end{array}$ & $\begin{array}{l}\text { Health Physics Regional } \\
\text { Monitoring, Weekly Report -- } \\
\text { Control }\end{array}$ & see note ${ }^{5}$ & NR & NR & NR \\
\hline May-1962 & $\begin{array}{l}\text { reactor discharge failed } \\
\text { Mark VB fuel element (\& } \\
12 \text { other Mark VB fuel } \\
\text { elements?) }\end{array}$ & $\begin{array}{l}\text { Health Physics Regional } \\
\text { Monitoring, Weekly Report -- } \\
\text { Control }\end{array}$ & see note ${ }^{6}$ & NR & NR & NR \\
\hline Jun-1962 & $\begin{array}{l}\text { reactor discharge Mark } \\
\text { VIIA fuel element }\end{array}$ & $\begin{array}{l}\text { Health Physics Regional } \\
\text { Monitoring, Weekly Report -- } \\
\text { Control }\end{array}$ & see note ${ }^{5}$ & NR & NR & NR \\
\hline Aug-1962 & $\begin{array}{l}\text { reactor discharge Mark } \\
\text { VIIA fuel element }\end{array}$ & $\begin{array}{l}\text { Health Physics Regional } \\
\text { Monitoring, Weekly Report -- } \\
\text { Control }\end{array}$ & see note ${ }^{5}$ & NR & NR & NR \\
\hline Mar-1963 & $\begin{array}{l}\text { reactor discharge Mark VB } \\
\text { fuel element }\end{array}$ & $\begin{array}{l}\text { Health Physics Regional } \\
\text { Monitoring, Monthly Summary } \\
\text { Report }\end{array}$ & & NR & NR & NR \\
\hline Jun-1963 & $\begin{array}{l}\text { reactor discharge Mark VB } \\
\text { fuel element }\end{array}$ & $\begin{array}{l}\text { Health Physics Regional } \\
\text { Monitoring, Monthly Summary } \\
\text { Report }\end{array}$ & & NR & NR & NR \\
\hline Sep-1963 & $\begin{array}{l}\text { reactor discharge Mark VB } \\
\text { fuel element }\end{array}$ & $\begin{array}{l}\text { Health Physics Regional } \\
\text { Monitoring, Monthly Summary } \\
\text { Report }\end{array}$ & see note ${ }^{7}$ & NR & NR & NR \\
\hline Oct-1963 & $\begin{array}{l}\text { reactor discharge Mark VB } \\
\text { fuel element }\end{array}$ & $\begin{array}{l}\text { Health Physics Regional } \\
\text { Monitoring, Monthly Summary } \\
\text { Report }\end{array}$ & & NR & NR & NR \\
\hline Nov-1963 & $\begin{array}{l}\text { reactor discharge Mark VB } \\
\text { fuel element }\end{array}$ & $\begin{array}{l}\text { Health Physics Regional } \\
\text { Monitoring, Monthly Summary } \\
\text { Report }\end{array}$ & see note ${ }^{8}$ & NR & NR & NR \\
\hline Jan-1965 & $\begin{array}{l}\text { reactor discharge of failed } \\
\text { Mark VB fuel element }\end{array}$ & $\begin{array}{l}\text { Radiological \& Environmental } \\
\text { Sciences Division, SRL, } \\
\text { Envrionmental Monitoring Group, } \\
\text { Monthly Report }\end{array}$ & $\begin{array}{l}\text { from disassembly basin a large I-131 } \\
\text { release ( } 73 \mathrm{Ci} \text { ) along with } 39 \mathrm{Ci} \text { of } \\
\text { primarily } \mathrm{Sr}-89,90 \text {; } \mathrm{Ce}-141,144 \text {; and } \\
\text { ZrNb-95 }\end{array}$ & $\begin{array}{l}0.28(\mathrm{Sr}- \\
90)\end{array}$ & NR & 26 \\
\hline Aug-1965 & $\begin{array}{l}\text { reactor discharge (in late } \\
\text { July) of Mark VB fuel } \\
\text { element }\end{array}$ & $\begin{array}{l}\text { Radiological \& Environmental } \\
\text { Sciences Division, SRL, } \\
\text { Envrionmental Monitoring Group, } \\
\text { Monthly Report }\end{array}$ & not reported & 0.1 & 1.2 & 120 \\
\hline Oct-1965 & $\begin{array}{l}\text { reactor discharge of Mark } \\
\text { VE fuel element }\end{array}$ & $\begin{array}{l}\text { Radiological \& Environmental } \\
\text { Sciences Division, SRL, } \\
\text { Envrionmental Monitoring Group, } \\
\text { Monthly Report }\end{array}$ & not reported & 0.12 & 2.51 & 1781 \\
\hline Dec-1965 & $\begin{array}{l}\text { reactor discharge of Mark } \\
\text { VE fuel element }\end{array}$ & $\begin{array}{l}\text { Radiological \& Environmental } \\
\text { Sciences Division, SRL, } \\
\text { Envrionmental Monitoring Group, } \\
\text { Monthly Report }\end{array}$ & not reported & 0.06 & 1.92 & 826 \\
\hline Jan-1970 & $\begin{array}{l}\text { reactor discharge of Mark } \\
30 \text { depeleted uranium target }\end{array}$ & $\begin{array}{l}\text { Radiological Sciences Division, } \\
\text { SRL, Envrionmental Monitoring } \\
\text { Group, Monthly Report }\end{array}$ & $\begin{array}{l}\text { in VTS (vertical tube storage in the } \\
\text { disassembly basin), peak value } 10.3 \mathrm{Ci} \\
\text { of Cr-51 \& } 1480 \mathrm{Ci} \text { tritium }\end{array}$ & 0.39 & 0.79 & 428 \\
\hline
\end{tabular}


WSRC-TR-2003-00142

March 25, 2003

Page 38 of 49

Appendix B Examples of Events in P Area Disassembly Basin History (continued)

\begin{tabular}{|c|c|c|c|c|c|c|}
\hline \multicolumn{7}{|c|}{ Examples of Events in Disassembly Basin History } \\
\hline \multirow[b]{2}{*}{ Date } & \multirow[b]{2}{*}{ Subject $^{1}$} & \multirow[b]{2}{*}{ Source } & \multirow[b]{2}{*}{ Disassembly Basin values } & \multicolumn{3}{|c|}{ reactor weir release $(\mathrm{Ci})$} \\
\hline & & & & ${ }^{89,90} \mathrm{Sr}$ & ${ }^{137} \mathrm{Cs}$ & ${ }^{3} \mathbf{H}$ \\
\hline Feb-1970 & $\begin{array}{l}\text { reactor discharge (in Dec) } \\
\text { of Mark } 30 \text { depeleted } \\
\text { uranium target }\end{array}$ & $\begin{array}{l}\text { Radiological Sciences Division, } \\
\text { SRL, Envrionmental Monitoring } \\
\text { Group, Monthly Report }\end{array}$ & $\begin{array}{l}\text { in VTS, peak value } 12.5 \mathrm{Ci} \text { of } \mathrm{Cr}-51 \& \\
1750 \mathrm{Ci} \text { tritium }\end{array}$ & 0.41 & 0.56 & 407 \\
\hline Mar-1970 & $\begin{array}{l}\text { reactor discharge of Mark } \\
30 \text { depeleted uranium target } \\
\& \text { Mark } 14 \text { fuel element }\end{array}$ & $\begin{array}{l}\text { Radiological Sciences Division, } \\
\text { SRL, Envrionmental Monitoring } \\
\text { Group, Monthly Report }\end{array}$ & $\begin{array}{l}\text { in VTS, peak value } 74 \mathrm{Ci} \text { of } \mathrm{Cr}-51 \& \\
5300 \mathrm{Ci} \text { tritium }^{9}\end{array}$ & 0.97 & 0.61 & 226 \\
\hline Jun-1970 & $\begin{array}{l}\text { reactor discharge of Mark } \\
30 \text { depeleted uranium target }\end{array}$ & $\begin{array}{l}\text { Radiological Sciences Division, } \\
\text { SRL, Envrionmental Monitoring } \\
\text { Group, Monthly Report }\end{array}$ & $\begin{array}{l}\text { in VTS, peak value } 17.1 \mathrm{Ci} \text { of } \mathrm{Cr}-51 \& \\
4011 \mathrm{Ci} \text { tritium }\end{array}$ & 0.64 & 0.68 & 665 \\
\hline Jul-1970 & $\begin{array}{l}\text { reactor discharge of Mark } \\
30 \text { depeleted uranium target }\end{array}$ & $\begin{array}{l}\text { Radiological Sciences Division, } \\
\text { SRL, Envrionmental Monitoring } \\
\text { Group, Monthly Report }\end{array}$ & $\begin{array}{l}\text { in VTS, peak value } 17 \mathrm{Ci} \text { of } \mathrm{Cr}-51 \& \\
1840 \mathrm{Ci} \text { tritium }\end{array}$ & 1.17 & 0.67 & 164 \\
\hline Aug-1970 & $\begin{array}{l}\text { reactor discharge of Mark } \\
30 \text { depeleted uranium target }\end{array}$ & $\begin{array}{l}\text { Radiological Sciences Division, } \\
\text { SRL, Envrionmental Monitoring } \\
\text { Group, Monthly Report }\end{array}$ & $\begin{array}{l}\text { in VTS, peak value } 24 \mathrm{Ci} \text { of } \mathrm{Cr}-51 \& \\
2398 \mathrm{Ci} \text { tritium }^{10}\end{array}$ & 0.8 & 2.54 & 510 \\
\hline Oct-1970 & $\begin{array}{l}\text { reactor discharge of Mark } \\
30 \text { depeleted uranium target } \\
\& \text { Mark } 14 \text { fuel element }\end{array}$ & $\begin{array}{l}\text { Radiological Sciences Division, } \\
\text { SRL, Envrionmental Monitoring } \\
\text { Group, Monthly Report }\end{array}$ & $\begin{array}{l}\text { in VTS, peak value } 39 \mathrm{Ci} \text { of } \mathrm{Cr}-51 \& \\
5500 \mathrm{Ci} \text { tritium }\end{array}$ & 0.22 & 0.15 & 256 \\
\hline Dec-1970 & $\begin{array}{l}\text { reactor discharge of Mark } \\
30 \text { depeleted uranium target }\end{array}$ & $\begin{array}{l}\text { Radiological Sciences Division, } \\
\text { SRL, Envrionmental Monitoring } \\
\text { Group, Monthly Report }\end{array}$ & $\begin{array}{l}\text { in VTS, peak value } 12 \mathrm{Ci} \text { of } \mathrm{Cr}-51 \& \\
3831 \mathrm{Ci} \text { tritium }\end{array}$ & 0.47 & 0.22 & 3115 \\
\hline Apr-1972 & $\begin{array}{l}\text { reactor discharge of Mark } \\
30 \text { depeleted uranium } \\
\text { target, Mark } 14 \text { fuel } \\
\text { element \& Mark } 40 \mathrm{Pu} \\
\text { target }\end{array}$ & $\begin{array}{l}\text { Health Physics Section, } \\
\text { Envrionmental Monitoring Group, } \\
\text { Monthly Report }\end{array}$ & not reported & 0.01 & 0.01 & 3294 \\
\hline May-1972 & $\begin{array}{l}\text { reactor discharge of Mark } \\
30 \text { depeleted uranium target }\end{array}$ & $\begin{array}{l}\text { Health Physics Section, } \\
\text { Envrionmental Monitoring Group, } \\
\text { Monthly Report }\end{array}$ & $\begin{array}{l}\text { not reported (VTS purge on } 5 / 13 \\
\text { included in release numbers) }\end{array}$ & 0.01 & 0.01 & 218 \\
\hline Jun-1972 & $\begin{array}{l}\text { reactor discharge of Mark } \\
30 \text { depeleted uranium target }\end{array}$ & $\begin{array}{l}\text { Health Physics Section, } \\
\text { Envrionmental Monitoring Group, } \\
\text { Monthly Report }\end{array}$ & not reported & 0.01 & 0.02 & 165 \\
\hline Jul-1972 & $\begin{array}{l}\text { reactor discharge of Mark } \\
30 \text { depeleted uranium target } \\
\& \text { Mark } 14 \text { fuel element }\end{array}$ & $\begin{array}{l}\text { Health Physics Section, } \\
\text { Envrionmental Monitoring Group, } \\
\text { Monthly Report }\end{array}$ & not reported & 0.04 & -- & 128 \\
\hline Dec-1972 & $\begin{array}{l}\text { reactor discharge of Mark } \\
30 \text { depeleted uranium target }\end{array}$ & $\begin{array}{l}\text { Health Physics Section, } \\
\text { Envrionmental Monitoring Group, } \\
\text { Monthly Report }\end{array}$ & not reported ${ }^{11}$ & 0.03 & 0.05 & 152 \\
\hline Oct-1976 & $\begin{array}{l}\text { reactor discharge of Mark } \\
31 \text { slug failure }\end{array}$ & $\begin{array}{l}\text { DuPont SRP Monthly Technical } \\
\text { Report DPSP-83-1-4 }\end{array}$ & not reported & NR & NR & NR \\
\hline 1977 & Disassembly Basin Purge & $\begin{array}{l}\text { January } 1978 \text { Health Physics } \\
\text { Department Environmental } \\
\text { Monitoring Monthly Report }\end{array}$ & see footnote ${ }^{12}$ & NR & NR & NR \\
\hline Nov-1978 & $\begin{array}{l}\text { reactor discharge of Mark } \\
31 \text { slug failure }\end{array}$ & $\begin{array}{l}\text { DuPont SRP Monthly Technical } \\
\text { Report DPSP-83-1-4 }\end{array}$ & not reported & NR & NR & NR \\
\hline Jun-1979 & $\begin{array}{l}\text { reactor discharge of Mark } \\
31 \text { slug failure }\end{array}$ & $\begin{array}{l}\text { DuPont SRP Monthly Technical } \\
\text { Report DPSP-83-1-4 }\end{array}$ & not reported & NR & NR & NR \\
\hline Dec-1979 & $\begin{array}{l}\text { reactor discharge of Mark } \\
31 \text { slug failure }\end{array}$ & $\begin{array}{l}\text { DuPont SRP Monthly Technical } \\
\text { Report DPSP-83-1-4 }\end{array}$ & not reported & NR & NR & NR \\
\hline Feb-1982 & $\begin{array}{l}\text { reactor discharge of Mark } \\
31 \text { slug failure }\end{array}$ & $\begin{array}{l}\text { DuPont SRP Monthly Technical } \\
\text { Report DPSP-83-1-4 }\end{array}$ & not reported & NR & NR & NR \\
\hline Jun-1982 & $\begin{array}{l}\text { reactor discharge of Mark } \\
31 \text { slug failure }\end{array}$ & $\begin{array}{l}\text { DuPont SRP Monthly Technical } \\
\text { Report DPSP-83-1-4 }\end{array}$ & not reported & NR & NR & NR \\
\hline Jan-1983 & $\begin{array}{l}\text { reactor discharge of Mark } \\
31 \text { slug failure }\end{array}$ & $\begin{array}{l}\text { DuPont SRP Monthly Technical } \\
\text { Report DPSP-83-1-4 }\end{array}$ & not reported & NR & NR & NR \\
\hline Mar-1983 & $\begin{array}{l}\text { reactor discharge of Mark } \\
31 \text { slug failure }\end{array}$ & $\begin{array}{l}\text { DuPont SRP Monthly Technical } \\
\text { Report DPSP-83-1-4 }\end{array}$ & not reported & NR & NR & NR \\
\hline Jul-1984 & $\begin{array}{l}\sim 100 \text { gallons of moderator } \\
\text { was inadvertently put in the } \\
\text { D\&E Canal during } \\
\text { discharge of elements } \\
\text { (reactor incident P-1620) }\end{array}$ & $\begin{array}{l}\text { DuPont SRP Monthly Technical } \\
\text { Report DPSP-84-1-7 }\end{array}$ & $\begin{array}{l}\text { VTS tritium levels increased from } \\
0.2 \mathrm{uCi} / \mathrm{mL} \text { to } 1.02 \mathrm{uCi} / \mathrm{mL} ; \mathrm{VTS} \text { water } \\
\text { was purged through deionizers to the } \\
\text { seepage basin to reduce tritium levels } \\
\text { to normal }\end{array}$ & NR & NR & NR \\
\hline
\end{tabular}


WSRC-TR-2003-00142

March 25, 2003

Page 39 of 49

\section{Appendix B Examples of Events in P Area Disassembly Basin History (continued)}

$\mathrm{NR}=$ not reported and/or not measure

${ }^{1}$ not clear in reports (particularly early reports) if discharges of elements are typical discharges or from failed elements

${ }^{2}$ failed element (3/6/59) was discharged to the emergency section of the disassembly basin but not contained in the "harps"; weekly report 3/16/59-3/22/59 noted contamination incident near fence of P-Area seepage basin; attributed to pumping of water from the emergency section of the P-Area disassembly basin to the seepage basin

${ }^{3}$ Weekly Report 4/6/59-4/10/59 noted that a radioactive gasket was found in the 105-P "clean" burning pit; item was found $15 \mathrm{mrad} / \mathrm{hr}$ at 2 " and radioactivity attributed to Co-60

${ }^{4} 2 \mathrm{Ci}$ estimated to have been released to seepage basins from Chalk River fuel elements; according to DPSP-59-1452 regarding the fuel element failure on $8 / 2 / 59$, a total of 24 failures had occurred in P-Area

${ }^{5}$ Weekly Report for 10/15/1962 records an investigation into the increase in Cr-51 released to Steel Creek from P-Area; find that in all of the cases, the type of fuel element discharged was the same (Mark VIIA); also note they are looking at the moderator and corrosion of stainless steel attachments; report also records an investigation related to radioisoptopes that adhere to the aluminum oxide film formed on the fuel elements during irradiation and are discharged with the elements into the disassembly basin water.

${ }^{6}$ Environmental Monitoring and Allied Studies report attributes increased radioactivity in Steel Creek to the "discharge of a failed Mark VB fuel element (a total of 13 elements including the failed element were discharged) in P-Area on 5/7"; radioiodine was found at the Steel Creek sampling location (Steel Creek Road A) in addition to at the sampling location at the 301 Crossing

${ }^{7}$ report noted that although the number of discharges and type of fuel discharged influence the quantities of radioactive materials released from the disassembly basins, fuel element failures contributed greatly to the increased releases during 1962 and 1963; in 1962 there were two failed Mark VB fuel elements discharged in P-Area and in 1963 a total of six failed Mark VB fuel elements discharged among P, C, and K-Areas; noted the impact that one failed element can have on yearly releases by highlighting a failed Mark VB element discharge in P-Area in 1962 which accounted for $60 \%$ of the long-lived radionuclides ( $64 \mathrm{Ci}$ ), $50 \%$ of the short-lived radionuclides $(178 \mathrm{Ci})$, and all of the $\mathrm{I}-131$ (77 Ci) released from P-Area disassembly basin for the year

${ }^{8}$ report noted that invesigations in R-Area have revealed that increased releases of Cs-134,137 are related to failed fuel elements in vented cans that are stored in open buckets in the disassembly basin; by removing several buckets of cans from the bucket storage section of the basin to the isolation tank, they were able to reduce the amount of Cs released

${ }^{9}$ noted in report about storage of partially declad irradiated fuel elements in the P-reactor Disassembly Basin (transferred from R-reactor disassembly basin in 1964); is the principal source of release of Cs-134 and Cs-137 to river; transfer of the $15 \mathrm{ft}$ cans to the Receiving Basin for offsite fuel (RBOF) began $11 / 1968$ and the final transfer took place $1 / 1970$

${ }^{10}$ noted in report about the increase in Cs-134-Cs-137 ratio in the releases from the disassembly basin to Steel Creek from stored material (Mark VR fuel, Zr clad fuel, uranium oxide filters and tubes; removal \& transfer of material in process)

Cs release from P-disassembly basin (Ci)

\begin{tabular}{|c|c|c|}
\hline \multicolumn{2}{c|}{ Cs release from P-disassembly basin (C1) } \\
\hline week ending & Cs-134 & Cs-137 \\
\hline $7 / 5 / 1970$ & -- & 0.11 \\
\hline $7 / 12 / 1970$ & -- & 0.16 \\
\hline $7 / 19 / 1970$ & -- & 0.32 \\
\hline $7 / 26 / 1970$ & -- & 0.56 \\
\hline $8 / 2 / 1970$ & 0.14 & 0.24 \\
\hline $8 / 9 / 1970$ & 0.21 & 0.47 \\
\hline $8 / 16 / 1970$ & 0.38 & 0.1 \\
\hline $8 / 23 / 1970$ & 0.1 & 0.34 \\
\hline
\end{tabular}

${ }^{11}$ 186-3P cooling water settling basin drained to Steel Creek on 9/5 and estimated $0.05 \mathrm{Ci}$ Cs-137 contained in sludge and released to effluent

${ }^{12}$ Purged at high rate to reduce tritium levels in disassembly basin following a reactor discharge; released $90 \mathrm{mCi}$ of ${ }^{137} \mathrm{Cs}$ to stream (Steel Creek); although the concentration of ${ }^{137} \mathrm{Cs}$ was small, the large volume of water discharged caused the ${ }^{137} \mathrm{Cs}$ release to be larger than expected and larger than the annual guide of 85 $\mathrm{mCi}$ 
WSRC-TR-2003-00142

March 25, 2003

Page 40 of 49

Appendix C Examples of Documented Leaks and Spills for P Reactor

\begin{tabular}{|c|c|c|}
\hline Date & Subject/Source & Description \\
\hline $12 / 14 / 1954$ & $\begin{array}{l}\text { Unusual Incident - moderator spill in } \\
\text { D Cell Sump 100-P }\end{array}$ & $\begin{array}{l}\text { estimated } 80 \text { gallons moderator overflowed to the Purification D cell sump; expected that } \\
\text { processing of spilled moderator through purification equipment will result in }>90 \% \\
\text { recovery }\end{array}$ \\
\hline $8 / 14 / 1959$ & $\begin{array}{l}\text { Reactor Incident RI-P-127 -- seal } \\
\text { cooler process water leak }\end{array}$ & $\begin{array}{l}\text { a weld failed on the process water outlet line of the no. } 4 \text { pump shaft seal cooler; } 3015 \mathrm{lbs} \text { of } \\
94.4 \% \text { moderator recovered from the } 208.1 \text { sump and attributed primarily to the leak }\end{array}$ \\
\hline $10 / 13 / 1959$ & $\begin{array}{l}\text { Reactor Incident RI-P-135 -- process } \\
\text { water leaks }\end{array}$ & $\begin{array}{l}\text { abnormal number of leaks occurred during the hydraulic startup 10/12; biggest was from no. } \\
5 \text { pump shaft seal }(50 \mathrm{gal} / \mathrm{hr}) ; 100 \mathrm{lbs} \text { of moderator were recovered from the }-40 \text { and the } \\
208.1 \text { sump drum }\end{array}$ \\
\hline $10 / 19 / 1959$ & $\begin{array}{c}\text { Reactor Incident RI-P-138 -- process } \\
\text { water leak at Valve } 84\end{array}$ & $\begin{array}{l}\text { a diaphragm failure caused process water leak on the }-40^{\prime} \text { level floor in front of the system } \\
\text { no. } 5 \text { Bingham pump; leakage rate } \sim 50 \mathrm{lbs} / \mathrm{hr} \text {; estimated } 500 \mathrm{lbs} \text { moderator lost }\end{array}$ \\
\hline $\begin{array}{l}\text { week of } 10 / 26-10 / 30 \\
1959\end{array}$ & $\begin{array}{l}\text { Weekly Report -- Control, P-Area } \\
\text { Seepage Basin }\end{array}$ & $\begin{array}{l}\text { water level in the } 100-\mathrm{P} \text { Seepage Basin } \# 2 \text { was higher than the berm causing the water to } \\
\text { "outcrop" approximately } 45 \text { feet from the basin; tritium sample from collected } 11 / 3 \text { from the } \\
\text { outcropped water measured } 440 \times 10-3 \mathrm{uCi} / \mathrm{L}\end{array}$ \\
\hline $\begin{array}{l}\text { week of } 11 / 9-11 / 13 \\
1959\end{array}$ & $\begin{array}{l}\text { Weekly Report -- Control, P-Area } \\
\text { Seepage Basins }\end{array}$ & $\begin{array}{l}\text { Pulse height analysis showed }>95 \% \text { of the alpha activity in the P-Area seepage basins is } \\
\text { from Pu-239; although overall concentration is low }(<0.3 \mathrm{~d} / \mathrm{m} / \mathrm{mL}) \text {, report acknowledges } \\
\text { that it is the first positive indication of } \mathrm{Pu}-239 \text { in the } 100 \mathrm{Areas} \text { seepage basin complex }\end{array}$ \\
\hline $11 / 28 / 1959$ & $\begin{array}{l}\text { Process Incident no. P-53 -- no. } 6 \\
\quad \text { Bingham pump seal failure }\end{array}$ & $\begin{array}{l}\text { leakage from a shaft seal of the no. } 6 \text { Bingham pump; water was later observed in the Far } \\
\text { Pump Room Sump; estimated unrecovered process water loss was } 630 \mathrm{lbs} \text { D2O; } 2450 \mathrm{lbs} \\
\text { (100\% basis) D2O was recovered from the Pump Room Sump }\end{array}$ \\
\hline $11 / 30 / 1959$ & $\begin{array}{l}\text { Reactor Incident RI-P-152 -- } \\
\text { Number } 6 \text { System Seal Leak }\end{array}$ & $\begin{array}{l}\text { on } 11 / 28 \text { shaft seal on system number } 6 \text { Bingham pump began leaking requiring reactor } \\
\text { shutdown on } 11 / 30 \text {; maximum leakage (on } 11 / 30 \text { ) to the } 208.1 \text { tank was } \sim 48 \mathrm{gal} / \mathrm{hr} ; 2498 \\
\text { lbs degraded moderator recovered in far sump; following hydraulic startup } 12 / 2 \text { systems } 1 \text {, } \\
2,4 \text {, \& } 6 \text { (again) were leaking }\end{array}$ \\
\hline $2 / 6 / 1960$ & $\begin{array}{c}\text { Process Incident no. P-54 -- process } \\
\text { water spill -- partially filled } \\
\text { deionizer }\end{array}$ & $\begin{array}{l}\text { a mixed bed deionizer from K-area was installed in A-cell in P-area; it was partially filled } \\
\text { with D2O when placed online (recirculation with the Purification Surge Tank); postulated } \\
\text { that the trapped air in the deionizer was forced out into the process water system causing } \\
\text { process water to spill on the plenum top and collect in the plenum leak collection drum }\end{array}$ \\
\hline $5 / 18 / 1960$ & $\begin{array}{l}\text { Reactor Incident RI-P-179 -- CIC } \\
\text { Effluent Header Leak }\end{array}$ & light water leak found in the eflluent drain system for the nuclear instruments \\
\hline $5 / 20 / 1960$ & Reactor Incident RI-P-177 & $\begin{array}{l}\text { process water leak discovered betweent the tube sheets of the 3B heat exchanger (at the hot } \\
\text { process water end) }\end{array}$ \\
\hline $6 / 22 / 1960$ & $\begin{array}{l}\text { Reactor Incident RI-P-188 -- process } \\
\text { water leak at Valve } 84\end{array}$ & $\begin{array}{l}\text { discovered a D2O leak between a pipe flange and a valve flange during a shutdown; upon } \\
\text { further inspection found that it was missing a gasket and speculated that it had been missing } \\
\text { since installation (1957); the amount of D2O lost could not be determined }\end{array}$ \\
\hline $6 / 23 / 1960$ & Reactor Incident RI-P-189 & $\begin{array}{l}\text { external leak at the hot process water end of the } 3 \mathrm{~B} \text { heat exchanger discovered from about } \\
10 \text { points with total leakage about } 200 \mathrm{drops} / \mathrm{min} \text {; installed a polythene covering to enclose } \\
\text { that end of the heat exchanger and connected a hose from the covering to a drum in the } 208 \text { - } \\
1 \text { sump to collect the process water; estimated that from } 6 / 8-6 / 29 \text { the rate increased from } \\
220 \text { drops } / \text { min to } 430 \mathrm{drops} / \mathrm{min} \text {; estimated from } 6 / 8-6 / 27 \sim 58 \mathrm{lbs} / \text { day leaked, } 6 / 2830 \\
\mathrm{lbs} / \text { day, and } 6 / 2940 \mathrm{lbs} / \text { day }\end{array}$ \\
\hline $6 / 23 / 1960$ & $\begin{array}{l}\text { Reactor Incident RI-P-192 -- process } \\
\quad \text { water leak at Valve } 85\end{array}$ & $\begin{array}{l}\text { Valve } 85 \text { leaked when flow to the purification system started during shutdown; the } \\
\text { diaphragm for the valve was replaced the day before when the process water line was } \\
\text { drained; the valve bonnet was not adequately tightened to prevent process water leakage } \\
\text { with the valve open when flow was initiated; the amount of D2O lost had not been } \\
\text { determined }\end{array}$ \\
\hline $6 / 29 / 1960$ & $\begin{array}{l}\text { Reactor Incident RI-P-193 -- } \\
\text { shutdown for 3B HX Tube Sheet } \\
\text { Space Leak }\end{array}$ & $\begin{array}{l}\text { reactor was shutdown because the external tube sheet leak of the } 3 \mathrm{~B} \text { heat exchanger could } \\
\text { not be contained within the polythene covering; leakage rate } \sim 200 \mathrm{drops} / \mathrm{min} \text { to the floor } \\
\text { and } \sim 100 \mathrm{lbs} \text { moderator were lost }\end{array}$ \\
\hline $6 / 30 / 1960$ & $\begin{array}{l}\text { Reactor Incident RI-P-195 -- process } \\
\text { water spill }\end{array}$ & $\begin{array}{l}\text { process water spilled when the flanges on the inlet end of } 3 \mathrm{~A} \text { and } 3 \mathrm{~B} \text { heat exchangers were } \\
\text { loosened; estimated } \sim 80 \text { gallons of process water spilled on the floor ( } 100 \mathrm{lbs} \text { of moderator } \\
\text { lost) }\end{array}$ \\
\hline $11 / 10 / 1960$ & $\begin{array}{l}\text { Top and bottom shield leak in P- } \\
\text { Area }\end{array}$ & $\begin{array}{l}\text { determined that there is inleakage of light water into moderator most likely from leak in in } \\
\text { top shield; calculations show that it is possible to have both inleakage and outleakage from } \\
\text { the same hole depending on the level in the surge tank; proposed to increase the pressure of } \\
\text { the moderator system so that it is greater than the light water (deionized) pressure and } \\
\text { leakage will be outward in the future (purity of moderator will be retained) }\end{array}$ \\
\hline
\end{tabular}


WSRC-TR-2003-00142

March 25, 2003

Page 41 of 49

Appendix C Examples of Documented Leaks and Spills for P Reactor (continued)

\begin{tabular}{|c|c|c|}
\hline Date & Subject/Source & Description \\
\hline $11 / 14 / 1961$ & $\begin{array}{l}\text { Reactor Incident RI-P-268 -- process } \\
\text { water spill -- charge machine }\end{array}$ & $\begin{array}{l}\text { during the start of a shutdown, a process water supply valve was open to the charge machine } \\
\text { and pressure was allowed to build up which spilled process water into the Charge and } \\
\text { Discharge machine process water supply system (and onto the process room floor); the } \\
\text { quantity of spilled process water could not be determined }\end{array}$ \\
\hline $11 / 16 / 1961$ & $\begin{array}{l}\text { Reactor Incident RI-P-269 -- } \\
\text { Cooling Water Header Leaks }\end{array}$ & $\begin{array}{l}\text { during a shutdown, leaks were discovered from the abandoned thermovells in the effluent } \\
\text { cooling water headers }\end{array}$ \\
\hline $12 / 17 / 1961$ & $\begin{array}{l}\text { Reactor Incident RI-P-271 -- Heat } \\
\text { Exchanger 4A Staybolt Leak }\end{array}$ & $\begin{array}{l}\text { reactor was shutdown because of excessive leakage from staybolts on the hot end of the heat } \\
\text { exchanger; a pencil size stream of moderator was flowing out of the plastic cover that is over } \\
\text { the head of the heat exchanger; } ~ 1900 \text { lbs moderator were lost; intially the leak (discovered } \\
12 / 4 \text { ) was collected in a drum (and changed when necessary) but by } 12 / 17 \text { the drum was } \\
\text { bypassed so that the water went to the } 208-1 \text { tank }\end{array}$ \\
\hline $11 / 15 / 1962$ & $\begin{array}{l}\text { Weekly Report -- Control, Reactor } \\
\text { Moderator Analysis }\end{array}$ & $\begin{array}{l}\text { two samples from L-Area and one sample from P-Area moderator were analyzed for Cs-137 } \\
\text { and Sr-90 as part of an investigation to determine the elevated radiostrontium concentrations } \\
\text { experienced in L-Area effluent streams after the recent discharge of Mark VI reactor load; } \\
\text { sample from P-Area (P- } 9 / 21) \text { had } 98.1 \mathrm{uCi} / \mathrm{mL} \text { total Sr, } 1.5 \mathrm{uCi} / \mathrm{mL} \mathrm{Sr}-90,96.6 \mathrm{uCi} / \mathrm{mL} \mathrm{Sr} \text { - } \\
89 \text {, and } 8.7 \mathrm{uCi} / \mathrm{mL} \mathrm{Cs}-137 \text { (as compared to } 190 \mathrm{uCi} / \mathrm{mL} \mathrm{Sr}-90 \text { and } 575 \mathrm{uCi} / \mathrm{mL} \mathrm{Cs-137} \mathrm{in} \\
\text { one of the L-Area samples) }\end{array}$ \\
\hline Aug-1965 & $\begin{array}{l}\text { Reactor Daily Report DPTT- } 8835 \\
\text { and DPTT- } 8845\end{array}$ & shutdown of $\mathrm{P}$ reactor on $8 / 1 / 65$ to correct moderator leakage from heat exchanger $1 \mathrm{~A}$ \\
\hline Aug-1965 & Reactor Daily Report DPTT- 8854 & $\begin{array}{l}\text { P Reactor again shutdown on } 8 / 3 / 65 \text { to correct moderator leakage from hot end side of heat } \\
\text { exchanger 1A; repaired the surface of the boss under the two stop-leak devices }\end{array}$ \\
\hline Aug-1965 & $\begin{array}{c}\text { Material Balance Monthly Report } \\
\text { DPSP-65-13-8 Composition of } \\
\text { Deuterium Inventory - } 86 \text { as of } \\
\text { August 31, } 1965 \\
\end{array}$ & $100 \mathrm{lbs}$ of moderator lost as a result of a leak on the reactor tank top \\
\hline Nov-1965 & $\begin{array}{l}\text { Material Balance Monthly Report } \\
\text { DPSP-65-13-11 Schedule Deuterium }\end{array}$ & $300 \mathrm{lbs}$ of moderator lost resulting from blow-back through vacuum pots \\
\hline Dec-1967 & $\begin{array}{c}\text { Material Balance Monthly Report } \\
\text { DPSP-67-13-12 Deuterium Report } \\
\text { of Composition of Ending Inventory } \\
\text { as of December 31, 1967 }\end{array}$ & $\begin{array}{l}1628 \mathrm{lbs} \text { of moderator accidently lost in Building 105-P resulting from the failure of a } \\
\text { section of tubing being used in a test system for measurement of differential pressure }\end{array}$ \\
\hline Nov-1968 & $\begin{array}{c}\text { Material Balance Monthly Report } \\
\text { DPSP-68-13-11 Deuterium Report } \\
\text { of Composition of Ending Inventory } \\
\text { as of November 30,1968 }\end{array}$ & $\begin{array}{l}25 \text { lbs of moderator accidently lost in P Area as a result of a hole in a drum of stored } \\
\text { moderator }\end{array}$ \\
\hline Dec-1968 & $\begin{array}{c}\text { Material Balance Monthly Report } \\
\text { DPSP-68-13-12 Deuterium Report } \\
\text { of Composition of Ending Inventory } \\
\text { as of December 31, } 1968\end{array}$ & $60 \mathrm{lbs}$ of moderator accidently lost in P Area from an overflowed drum \\
\hline Feb-1969 & $\begin{array}{l}\text { Material Balance Monthly Report } \\
\text { DPSP-69-13-9 Schedule Deuterium }\end{array}$ & $\begin{array}{l}120 \mathrm{lbs} \text { of moderator were accidently lost in Building } 105-\mathrm{P} \text { from a spill from valve } \# 85 \\
(\sim 100 \mathrm{lbs}) \text { and from a tank top leak }(\sim 20 \mathrm{lbs})\end{array}$ \\
\hline Feb-1971 & $\begin{array}{l}\text { Material Balance Monthly Report } \\
\text { DPSP-71-13-2 Schedule Deuterium }\end{array}$ & $\begin{array}{l}105 \text { lbs of moderator estimated to have been lost as unrecovered moderator from three } \\
\text { separate spill events in P Area during C\&D outage; estimated } 5 \text { lbs lost from rotovalve } \\
\text { packing leak on } 1 / 25 ; 50 \text { lbs lost due to tank top leak on } 1 / 30 ; 50 \text { lbs lost due to tank top } \\
\text { leak on } 2 / 2\end{array}$ \\
\hline Apr-1971 & $\begin{array}{l}\text { Material Balance Monthly Report } \\
\text { DPSP-71-13-4 Schedule Deuterium }\end{array}$ & $\begin{array}{l}175 \mathrm{lbs} \text { of moderator were lost from spills in P Area during general overhaul maintenance of } \\
\text { the distillation facility (estimated } 150 \mathrm{lbs}) \text { and the replacement of a deionizer }(25 \mathrm{lbs})\end{array}$ \\
\hline Jun-1971 & $\begin{array}{l}\text { Material Balance Monthly Report } \\
\text { DPSP-71-13-6 Schedule Deuterium }\end{array}$ & $\begin{array}{l}20 \mathrm{lbs} \text { moderator lost from tank top leak during scram recovery on } 5 / 31 \text { in P Area; a S-foil } \\
\text { guide tube retaining pin was found to have broken }\end{array}$ \\
\hline Jul-1971 & $\begin{array}{l}\text { Material Balance Monthly Report } \\
\text { DPSP-71-13-7 Schedule Deuterium }\end{array}$ & $\begin{array}{l}48 \text { lbs of moderator were accidently lost in P Area Reactor Department due to drippage from } \\
\text { a piping connection }\end{array}$ \\
\hline
\end{tabular}


WSRC-TR-2003-00142

March 25, 2003

Page 42 of 49

Appendix C Examples of Documented Leaks and Spills for P Reactor (continued)

\begin{tabular}{|c|c|c|}
\hline Date & Subject/Source & Description \\
\hline Aug-1971 & $\begin{array}{l}\text { Material Balance Monthly Report } \\
\text { DPSP-71-13-8 Schedule Deuterium }\end{array}$ & $\begin{array}{l}50 \text { lbs of moderator were accidently lost in P Area Reactor Department due to tank top leak } \\
\text { caused by delatched APM and DC rods and O-rings which appeared to be of questionable } \\
\text { quality }\end{array}$ \\
\hline Sep-1971 & $\begin{array}{l}\text { Material Balance Monthly Report } \\
\text { DPSP-71-13-9 Schedule Deuterium }\end{array}$ & $\begin{array}{l}10 \mathrm{lbs} \text { of moderator were accidently lost due to a poor connection when a new evaporator } \\
\text { dip tube was installed in P Area; } 30 \mathrm{lbs} \text { of moderator were accidently lost from pressure } \\
\text { build up when two deionizers stored in P Area were vented }\end{array}$ \\
\hline Nov-1971 & $\begin{array}{l}\text { Material Balance Monthly Report } \\
\text { DPSP-71-13-11 Schedule Deuterium }\end{array}$ & $\begin{array}{l}10 \mathrm{lbs} \text { of moderator were accidently lost due to a poor connection when a new evaporator } \\
\text { dip tube was installed in P Area; } 30 \mathrm{lbs} \text { of moderator were accidently lost from pressure } \\
\text { build up when two deionizers stored in P Area were vented }\end{array}$ \\
\hline Feb-1972 & $\begin{array}{l}\text { Material Balance Monthly Report } \\
\text { DPSP-72-13-2 Schedule Deuterium }\end{array}$ & $10 \mathrm{lbs}$ of moderator were lost in P Reactor from leakage of a poorly seated septifoil O-ring \\
\hline Apr-1972 & $\begin{array}{l}\text { Material Balance Monthly Report } \\
\text { DPSP-72-13-4 Schedule Deuterium }\end{array}$ & $\begin{array}{l}406 \text { lbs of moderator were lost in the P Reactor Department from the blanket gas system due } \\
\text { to a leak through the diaphram and packing of an isolation valve situated between the reater } \\
\text { and purification section }\end{array}$ \\
\hline Aug-1972 & $\begin{array}{l}\text { Material Balance Monthly Report } \\
\text { DPSP-72-13-8 Schedule Deuterium }\end{array}$ & $\begin{array}{l}65 \text { lbs of moderator were lost in P Area Reactor Deparment during replacement of a } \\
\text { defective heat exchanger; } 9 \mathrm{lbs} \text { of moderator were lost from leakage of damaged and } \\
\text { displaced O-rings for two safety rod thimbles }\end{array}$ \\
\hline Sep-1972 & $\begin{array}{l}\text { Material Balancet Monthly Report } \\
\text { DPSP-72-13-9 Schedule Deuterium }\end{array}$ & $\begin{array}{l}70 \mathrm{lbs} \text { of moderator were accidently lost in Building } 105-\mathrm{P} \text { from a spill in the P Reactor } \\
\text { Room when the blanket gas system was pressurized during startup; the leakage came from an } \\
\text { unlatched thermocouple rod; most of the spilled moderator evaporated and was vented out } \\
\text { the stack }\end{array}$ \\
\hline Apr-1974 & $\begin{array}{l}\text { Material Balance Monthly Report } \\
\text { DPSP-74-13-4 Schedule Deuterium }\end{array}$ & $\begin{array}{l}5 \text { lbs of moderator accidently lost in P Area Reactor Department when the vacuum breaker } \\
\text { blew out while pressurizing the blanket gas system }\end{array}$ \\
\hline May-1974 & $\begin{array}{l}\text { Material Balance Monthly Report } \\
\text { DPSP-74-13-5 Schedule Deuterium }\end{array}$ & $\begin{array}{l}10 \mathrm{lbs} \text { of moderator accidently lost in Reactor Department, Building } 105-\mathrm{P} \text { from coolant } \\
\text { return tank overflow into hot sump; total overflow was } 341 \mathrm{lbs} \text {; all but } 10 \mathrm{lbs} \text { were recovered }\end{array}$ \\
\hline Jul-1974 & $\begin{array}{l}\text { Material Balance Monthly Report } \\
\text { DPSP-74-13-7 Schedule Deuterium }\end{array}$ & $\begin{array}{l}14.5 \mathrm{~kg}(\sim 32 \mathrm{lbs}) \text { moderator lost in Reactor Department at P Area from a leak though a } \\
\text { broken inhibitor system sightglass }\end{array}$ \\
\hline Jan-1975 & $\begin{array}{l}\text { Reactor Daily Report DPTT 75-2- } \\
\text { 7C and DPTT 75-2-4 }\end{array}$ & $\begin{array}{l}\text { P Reactor shut down on } 1 / 30 \text { to correct moderator leak in pin room; estimated D2O loss was } \\
465 \mathrm{lbs} \text {; approximately } 200 \mathrm{lbs} \text { of } 92 \% \mathrm{D} 2 \mathrm{O} \text { was recovered in collection systems }\end{array}$ \\
\hline Feb-1975 & Reactor Daily Report DPTT 75-2-20 & $\begin{array}{l}\text { emergency D2O cooling water was needed due to problems during the discharge of a Mark } \\
31 \mathrm{~B} \text { assembly; approximately } 1100 \mathrm{lbs} \text { of } \mathrm{D} 2 \mathrm{O} \text { were collected from the reactor top and } \\
\text { process room floor drain pots; initial estimate of } 400 \mathrm{lbs} \text { of } \mathrm{D} 2 \mathrm{O} \text { loss resulting from the } \\
\text { incident }\end{array}$ \\
\hline May-1975 & $\begin{array}{l}\text { Material Balance Monthly Report } \\
\text { DPSP-75-13-2 Schedule Deuterium }\end{array}$ & $\begin{array}{l}233.6 \mathrm{~kg}(\sim 514 \mathrm{lbs}) \text { of moderator accidently lost at Building } 105-\mathrm{P} \text { from an instrument } \\
\text { tubing leak in the pin room below the reactor; } 186 \mathrm{~kg}(\sim 409 \mathrm{lbs}) \text { loss of moderator while } \\
\text { providing emergency D2O cooling for an irradiated assembly stuck in the reactor }\end{array}$ \\
\hline Aug-1975 & $\begin{array}{l}\text { Reactor Daily Report DPTT 75-8- } \\
\qquad 13 \mathrm{~A}\end{array}$ & $\begin{array}{l}\text { shutdown of P reactor because of continuing indications of moderator leakage in the }-20 \text { and } \\
40 \text { elevations of building; moderator leak was found at the } 4 \mathrm{~B} \text { heat exchanger expansion } \\
\text { joint; since shutdown leakage has been contained and the leakage rate is estimated at } 1.5 \\
\text { gallons/hour }\end{array}$ \\
\hline Aug-1975 & Reactor Daily Report DPTT 75-8-19 & loss from the distillation overheads spill (reported on $8 / 15$ ) was approximately $19 \mathrm{lbs}$ D2O \\
\hline
\end{tabular}


WSRC-TR-2003-00142

March 25, 2003

Page 43 of 49

Appendix C Examples of Documented Leaks and Spills for P Reactor (continued)

\begin{tabular}{|c|c|c|}
\hline Date & Subject/Source & Description \\
\hline Jan-1977 & $\begin{array}{l}\text { Material Balance Monthly Report } \\
\text { DPSP-77-13-1 Schedule Deuterium }\end{array}$ & $\begin{array}{l}200.5 \mathrm{~kg}(\sim 441 \mathrm{lbs}) \text { of moderator accidently lost at Building } 105-\mathrm{P} \text { resulting from a leak at a } \\
\text { deionizer jumper following the replacement of a deionizer }\end{array}$ \\
\hline Mar-1978 & $\begin{array}{c}\text { Jan } 1979 \text { Health Physics Dept } \\
\text { Environmental Monitoring Monthly } \\
\text { Report and Environmental } \\
\text { Monitoring at the Savannah River } \\
\text { Plant Annual Report for } 1978 \\
\text { DPSPU 79-302 } \\
\end{array}$ & $\begin{array}{l}\text { higher than normal release of tritium to P Process Sewer (400 Ci in March; } 1,116 \mathrm{Ci} \text { for } \\
\text { year; } 300 \text { is the annual guide; attributed to isolated spill of D2O) }\end{array}$ \\
\hline May-1978 & Reactor Incident RI-P-1131 & $\begin{array}{l}\text { effluent hose from deionizer failed and released approximately } 4000 \text { gallons of deionizer } \\
\text { basin water containing approximately } 6 \text { Ci of tritium and neglible amounts of other isotopes } \\
\text { to the plant effluent stream; inspection of the hose revealed a } 6 \text { inch split around the } \\
\text { cirmcumference; hose had been in service for } 2 \text { years and was periodically inspected and } \\
\text { pressure tested }\end{array}$ \\
\hline Jun-1978 & Reactor Incident RI-P-1144 & $\begin{array}{l}\text { effluent hose from deionizer failed and released approximately } 300 \text { gallons of deionizer } \\
\text { basin water containing approximately } 0.4 \mathrm{Ci} \text { of tritium and neglible amounts of other } \\
\text { isotopes to the plant effluent stream; inspection of the hose revealed a } 9 \text { inch split around the } \\
\text { cirmcumference; hose had been in service for } 2 \text { years and was periodically inspected and } \\
\text { pressure tested }\end{array}$ \\
\hline Mar-1979 & Reactor Incident RI-P-1202 & $\begin{array}{l}\text { 3.3 } \mathrm{Ci} \text { of tritium and } 0.8 \mathrm{Ci} \text { of miscellaneous isotopes released when } 500 \text { gallons } \\
\text { contaminated water from top and bottom shield system overflowed in Building } 109\end{array}$ \\
\hline Mar-1980 & Reactor Incident RI-P-1291 & drained basin water to process sewer instead of to drums as required by procedure \\
\hline Jul-1980 & $\begin{array}{l}\text { Material Balance Monthly Report } \\
\text { DPSP-80-13-7 Schedule Deuterium }\end{array}$ & $\begin{array}{l}24.9 \mathrm{~kg}(\sim 55 \mathrm{lbs}) \text { of moderator were lost in Building } 105-\mathrm{P} \text {; the material was released to the } \\
\text { environment when heavy water leaked through an unseated check valve }\end{array}$ \\
\hline Mar-1982 & Reactor Incident RI-P-1451 & $\begin{array}{l}70 \mathrm{Ci} \text { of tritium were released to process sewer when an inhibitor system rotometer broke; } \\
60 \text { gallons of deionized water ( } 2 \% \mathrm{D} 2 \mathrm{O}) \text { flowed into the } 216 \mathrm{~B} \text { sump which discharges to the } \\
\text { process sewer; classified as equipment failure (rotometer broke) }\end{array}$ \\
\hline Jan-1983 & Reactor Incident RI-P-1501 & $\begin{array}{l}182 \mathrm{Ci} \text { tritium released to process sewer due to procedure deviation (personnel error); } \\
\text { personnel pumped the distillation hold tank contents to the process sewer without } \\
\text { authorization and sampling }\end{array}$ \\
\hline Feb-1983 & $\begin{array}{l}\text { DuPont SRP Monthly Technical } \\
\text { Report DPSP-83-1-2 }\end{array}$ & $\begin{array}{l}\text { P Area disassembly basin filter tank developed a leak in the bottom of the tank requiring } \\
\text { shut down of the filtering system; overpressurization led the bottom section (1/4" carbon } \\
\text { steel plate) to bow out and I-beam supports welds to fail; during time while waiting for } \\
\text { replacement tank, main basin water was to be piped through the vertical tube storage filter } \\
\text { loop }\end{array}$ \\
\hline Nov-1983 & Reactor Incident RI-P-1564 & $\begin{array}{l}\text { approximately } 730 \text { gallons of disassembly basin water were inadvertently released to the } \\
\text { process sewer during annual testing of the confinement heat removal valves; basin water was } \\
\text { drained to the } 216 \mathrm{~B} \text { sump instead of the } 1206 \mathrm{~B} \text { sump and subsequently pumped to the } \\
\text { process sewer; } 0.58 \mathrm{Ci} \text { of tritium and less than } 0.0008 \mathrm{Ci} \text { of other radionuclides were } \\
\text { released to the process sewer; the release was less than } 0.2 \% \text { fo the annual guide }(300 \mathrm{Ci} \text { ) }\end{array}$ \\
\hline Dec-1983 & $\begin{array}{l}\text { DuPont SRP Monthly Technical } \\
\text { Report DPSP-83-1-12 }\end{array}$ & $\begin{array}{l}\text { small moderator leak occurred on } 105-\mathrm{P} \text { distillation pad from a broken line (attributed to } \\
\text { freezing); estimated } 85 \mathrm{Ci} \text { of tritium were released to Steel Creek via storm sewer (caused } \\
\text { the annual tritium release guide of } 300 \mathrm{Ci} \text { to streams via process sewer to be exceeded) }\end{array}$ \\
\hline Jul-1984 & $\begin{array}{l}\text { DuPont SRP Monthly Technical } \\
\text { Report DPSP-84-1-7 \& RI-P-1620 }\end{array}$ & $\begin{array}{l}\text { VTS (vertical tube storage) tritium levels increased from } 0.25 \mathrm{uCi} / \mathrm{mL} \text { to } 1.0 \mathrm{uCi} / \mathrm{mL} \text { when } \\
\text { approximately } 85 \text { gallons }(800 \mathrm{lbs} \text { ) of moderator was inadvertently put in the D\&E Canal } \\
\text { due to binding difficulties during the discharge of a Mark } 42 \text { assembly; VTS water was } \\
\text { purged through deionizers to the seepage basin to reduce tritium levels to normal (estimated } \\
\text { value of the lost } 800 \mathrm{lbs} \text { of D2O }=\$ 60,000 \text { ) }\end{array}$ \\
\hline
\end{tabular}


Appendix D Mass Balance Calculations of ${ }^{137}$ Cs in P Reactor Seepage Basins

Using the data reviewed from this source term search, a simple mass balance analyses was performed for seepage basin \#1. This seepage basin, the first in a series of three basins that received effluent from $\mathrm{P}$ Reactor, contains the most radioactive contamination of the three basins based on sediment sampling. The mass balance results are summarized below along with the assumptions and methods used.

Approximately $7.94 \mathrm{Ci}$ of ${ }^{137} \mathrm{Cs}$ remains undecayed from the original discharges of ${ }^{137} \mathrm{Cs}$ to the seepage basins. This value was calculated by decay correcting the annual releases of ${ }^{137}$ Cs provided in "Radioactive Releases at the Savannah River Site 1954-1989 (U)" (14). The mass balance calculations provided below support that this remaining ${ }^{137} \mathrm{Cs}$ is predominantly bound in the sediments beneath the basins, particularly beneath seepage basin \#1. More specifically, the calculated median of ${ }^{137} \mathrm{Cs}$ remaining in the sediments of basin \#1 (7.73 Ci) appears to be a close estimate of the decayed corrected ${ }^{137} \mathrm{Cs}$ released to the basins $(7.94 \mathrm{Ci})$. When using averages rather than medians, the calculated ${ }^{137} \mathrm{Cs}$ remaining in the sediments of basin \#1(13 Ci) is higher than the decayed corrected ${ }^{137} \mathrm{Cs}$ released to the basins $(7.94 \mathrm{Ci})$. However, the decay corrected value falls in the range of the $90 \%$ confidence intervals calculated for the average. Because the initial concentration distribution of ${ }^{137} \mathrm{Cs}$ in the sediments is skewed by a few high values, the method based on median values (rather than averages) may provide a more reliable estimate of the remaining inventory.

A similar methodology and mass balance calculation shows that the sediments in seepage basin \#2 contain a smaller portion of the original curies of ${ }^{137} \mathrm{Cs}$ released to the seepage basins. Nevertheless, the calculated median value of ${ }^{137} \mathrm{Cs}$ remaining in the sediments of basin \#2 $(0.26 \mathrm{Ci})$ brings the mass balance nearer to closure supporting that the ${ }^{137} \mathrm{Cs}$ released to the basins predominantly remains in the sediments below the basins.

Assumptions and methodology used in mass balance calculations:

- $\quad$ Sediment bulk density $=1.89 \mathrm{~g} / \mathrm{cm}^{3}$

- Total basin area for seepage basin \#1 =20,000 $\mathrm{ft}^{2}$ (based on dimensions given in the report "Unit-Specific Plug-In TER for the P-Reactor", Reference \# 21; outside dimensions for N-S portion of the basin $=211^{\prime} \mathrm{X} 50$ ' and for the E-W portion of the basin $=254^{\prime}$ X 50'; rounded down in order to roughly estimate inner area of the basin without the sloping sides)

- Depth of contamination =10' (according to the report "Unit-Specific Plug-In TER for the P-Reactor", Reference \# $21,95 \%$ of the total activity in basin \#1 is within the top 10' of soil beneath the basin)

- Seepage basin \#1 received most of ${ }^{137}$ Cs released to the seepage basins (basin \#1 was the first in the series of three basins to receive discharged effluent from the reactor; sediment sampling from in the report "Unit-Specific Plug-In TER for the P-Reactor", Reference \# 21, also confirm that it contains the most radioactivity of the three basins)

- For the ${ }^{137}$ Cs activity discharged to the seepage basins used the 1998 cumulative ${ }^{137} \mathrm{Cs}$ activity (decay corrected) $=7.94 \mathrm{Ci}$ (data for ${ }^{137} \mathrm{Cs}$ activity discharged to the 
basins from "Radioactive Releases at the Savannah River Site 1954-1989 (U)", Reference \#14)

- For the ${ }^{137} \mathrm{Cs}$ activity in the sediments of the basin used the data provided in the report "Unit-Specific Plug-In TER for the P-Reactor", Reference \# 21, down to 10 ' (see "Depth of contamination" bullet above); only used data from borings that were completed to 10'; much of this data was collected in 1998; for the two borings that had no ${ }^{137} \mathrm{Cs}$ value listed due to saturation, assumed a ${ }^{137} \mathrm{Cs}$ concentration for the initial foot interval similar to the value listed for the next interval (see attached data)

- In an attempt to simply but accurately capture a realistic distribution of contamination in seepage basin \#1, the following methodology was used:

1. Split seepage basin \#1 into 4 zones (A through D) based on areas of similar contamination in the sediments (Zone A had the highest radioactivity and deepest contamination); see attached diagram for zones

2. For each zone, divided the $10 \mathrm{ft}$ (depth) of contamination into four layers; layer $1=1^{\text {st }}$ foot beneath basin bottom; layer $2=$ next 3 feet beneath bottom; layer 3 = next 3 feet; layer 4 = last 3 feet of contamination (depth of contamination assumed to be $10^{\prime}$ - see above bullet)

3. Calculated average (or mean) and median ${ }^{137} \mathrm{Cs}$ activity (using sediment data) for each layer for each zone; upper and lower $90 \%$ confidence intervals were also calculated for the average in order to show the uncertainties associated with the estimates; see attached sheet with calculations

- Compared the results of these calculations (i.e. the ${ }^{137} \mathrm{Cs}$ found in the sediments within seepage basin \#1) with the 1998 cumulative ${ }^{137} \mathrm{Cs}$ activity (decay corrected) released to the basins

Caveats of mass balance calculations:

- Ambiguity of the contaminant distribution in the seepage basin will account for some error or uncertainty in the calculations (leading to either underestimation or overestimation of ${ }^{137} \mathrm{Cs}$ in the basin). Knowledge of the distribution of contamination is constrained to the analytical data provided by the sediment samples. The methodology developed and used in the above calculations (Zones A-D and Layers 1-4) is based on the sediment sampling and therefore may not fully depict the contaminant distribution.

- Some error or uncertainty will also exist in the total area used for seepage basin \#1 and the assumed depth of contamination (10'). Because only a rough estimate of the outside dimensions of seepage basin \#1 was known, the area of the center of the basin where most of the contamination was likely deposited (i.e. not on the sloping sides) had to be approximated. For a small area of seepage basin \#1 (particularly in Zone A), the assumed depth of contamination (10') did not include all of PTSM $\left({ }^{137} \mathrm{Cs} \geq 86 \mathrm{pCi} / \mathrm{g}\right)$ and may account for an underestimation of the amount of ${ }^{137} \mathrm{Cs}$ remaining in the sediments.

- The average (or mean) and median will be affected by the small sample populations within each zone and layer. The methodology used tries to simply but accurately capture a realistic distribution of contamination within the basin by 
WSRC-TR-2003-00142

March 25, 2003

Page 46 of 49

making the assumption that the layers within each zone are similar. Assuming that each layer within a given zone might be normally distributed, an average (or mean) was calculated for each layer of each zone in order to try to capture a realistic ${ }^{137} \mathrm{Cs}$ activity present in different sections of the basin. The calculated upper and lower $90 \%$ confidence intervals show the uncertainty associated with the averages used in this methodology. However, the distribution within these zones and layers identified may not be normally distributed (as often found in environmental sampling). Factors such as differences in discharges and volumes (which would have affected the spread or dissemination of contaminants in the basin), the slope of the basin and heterogeneities within sediments below the basin could produce non-normal distributions. Therefore, a median was calculated in addition to the mean in an attempt to provide a descriptive statistic that might be more realistic. Overall, the sparse data within each layer and zone presents difficulty in computing good estimates (whether using the mean or median) of the contamination.

- The original measurements of release of ${ }^{137} \mathrm{Cs}$ are strongly dominated by the release(s) during a single year, 1959. (Weekly environmental and health monitoring reports suggest that an atypical discharge of a failed element and the handling of developmental reactor fuels may have contributed to the increased releases of radionuclides to P Reactor's seepage basins for this year. An overflow of the seepage basins which occurred in October 1959 would also suggest that the basins were receiving extensive use during this period.) Release estimates at that time were based on total counts and expected isotopic ratios that might vary somewhat over time. As a result, the decay corrected source input may be less accurate than one resulting from steady inputs over many years (i.e. based on many measurements). 


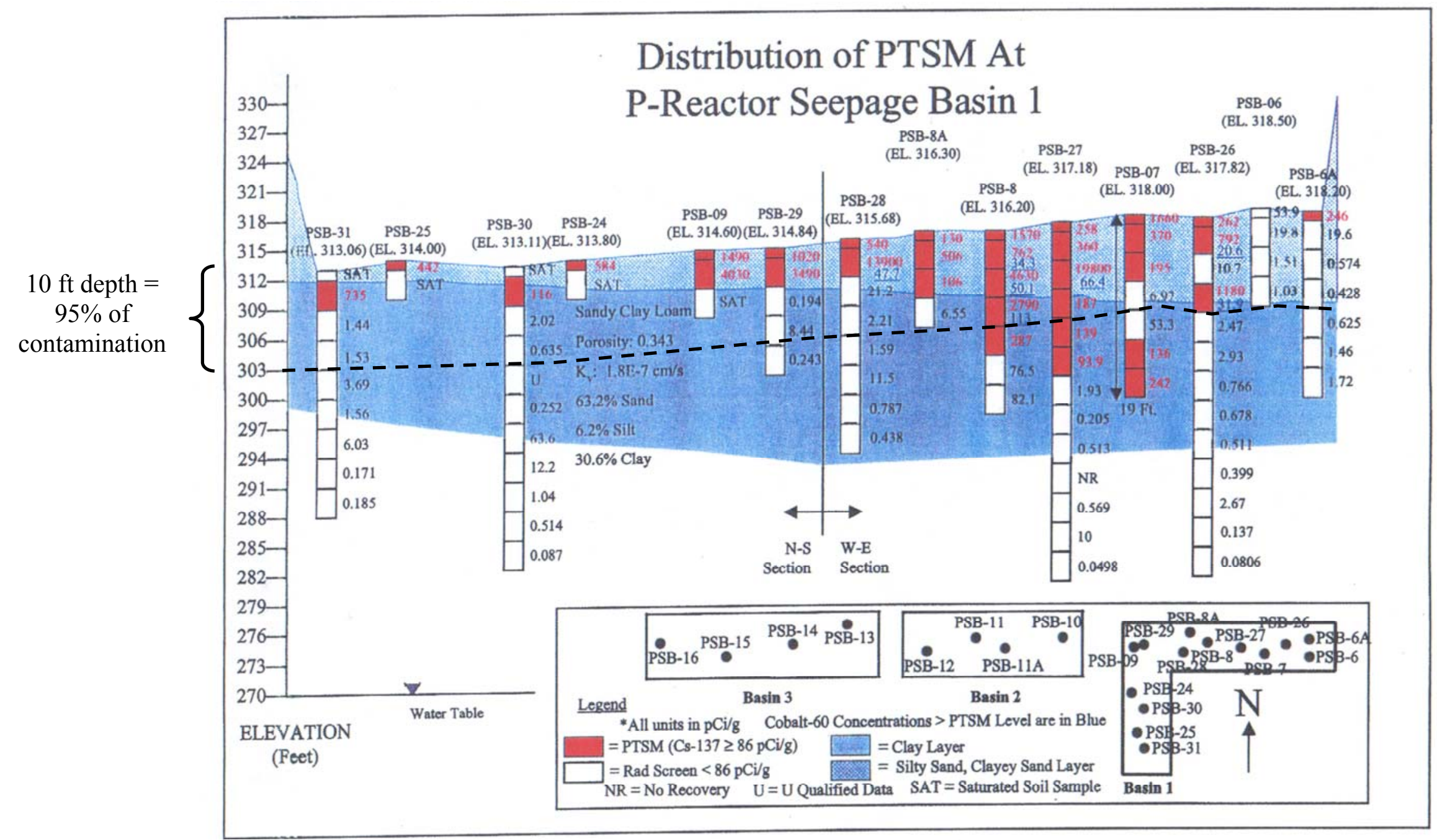

(Figure modified from the report "Unit-Specific Plug-In TER for the P-Reactor", Reference \# 21) 
WSRC-TR-2003-00142

March 25, 2003

Page 48 of 49

Zones A-D and sample locations used for determining distribution of ${ }^{137} \mathrm{Cs}$ in seepage basin \#1
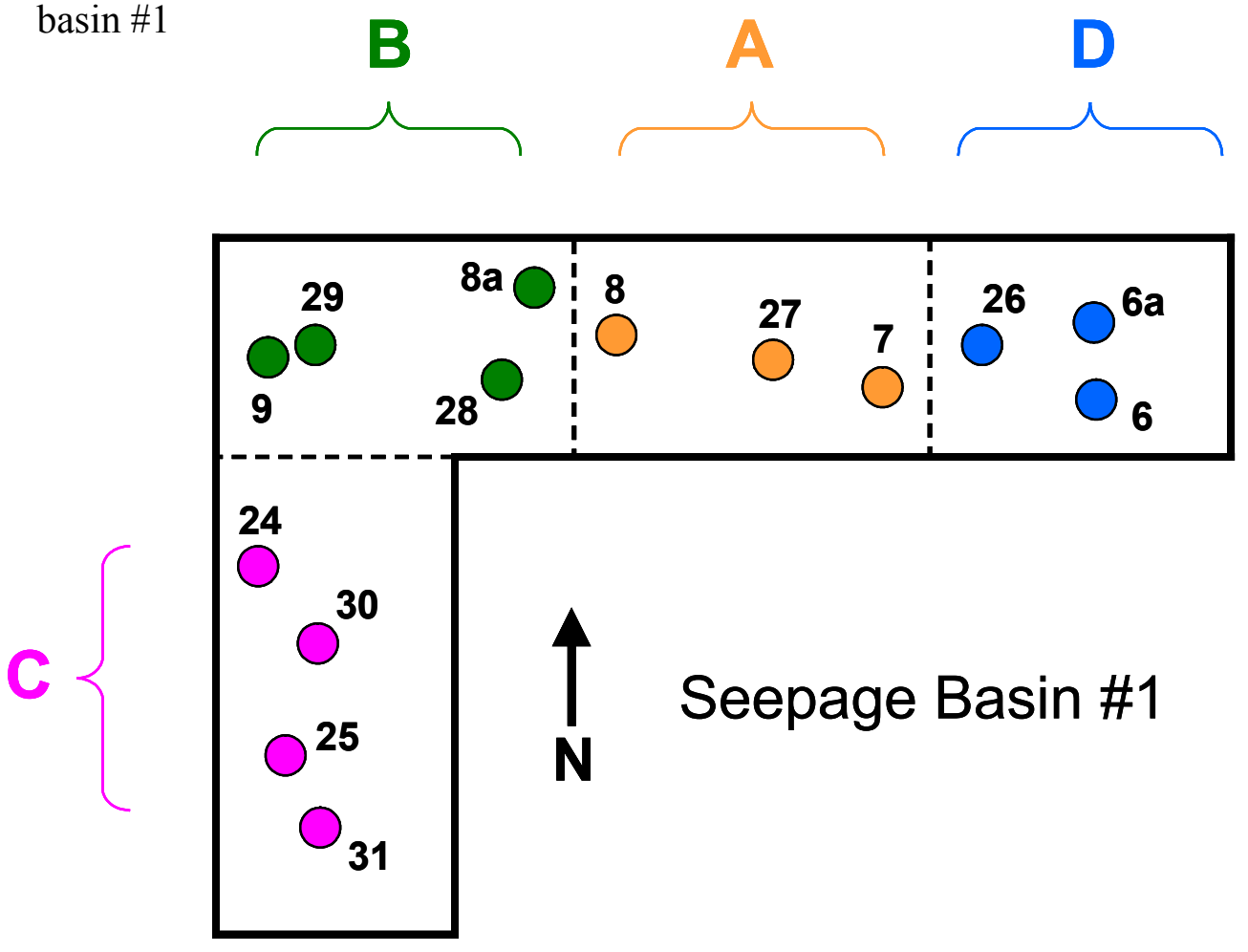

Sediment data (from the report "Unit-Specific Plug-In TER for the P-Reactor", Reference \# 21) used in calculations of ${ }^{137} \mathrm{Cs}$ remaining in seepage basin \#1

\begin{tabular}{|c|c|c|}
\hline Sample & Depth & ${ }^{137}$ Cs pCi/g \\
\hline PSB 31 & 0 to 1 & 700 \\
\hline PSB 31 & 1 to 4 & 735 \\
\hline PSB 31 & 4 to 7 & 1.44 \\
\hline PSB 31 & 7 to 10 & 1.53 \\
\hline PSB 30* & 0 to 1 & 100 \\
\hline PSB 30 & 1 to 4 & 116 \\
\hline PSB 30 & 4 to 7 & 2.02 \\
\hline PSB 30 & 7 to 10 & 0.635 \\
\hline PSB 29 & 0 to 1 & 1020 \\
\hline PSB 29 & 1 to 4 & 3490 \\
\hline PSB 29 & 4 to 7 & 0.194 \\
\hline PSB 29 & 7 to 10 & 8.44 \\
\hline PSB 28 & 0 to 1 & 540 \\
\hline PSB 28 & 1 to 4 & 13900 \\
\hline PSB 28 & 4 to 7 & 21.2 \\
\hline PSB 28 & 7 to 10 & 2.21 \\
\hline PSB 8A & 0 to 1 & 130 \\
\hline PSB 8A & 1 to 4 & 506 \\
\hline PSB 8A & 4 to 7 & 106 \\
\hline PSB 8A & 7 to 10 & 6.55 \\
\hline PSB 8 & 0 to 1 & 1570 \\
\hline PSB 8 & 1 to 4 & 762 \\
\hline PSB 8 & 4 to 7 & 4630 \\
\hline PSB 8 & 7 to 10 & 2790 \\
\hline
\end{tabular}

\begin{tabular}{|c|c|c|}
\hline Sample & Depth & ${ }^{137}$ Cs pCi/g \\
\hline PSB 27 & 0 to 1 & 258 \\
\hline PSB 27 & 1 to 4 & 360 \\
\hline PSB 27 & 4 to 7 & 19800 \\
\hline PSB 27 & 7 to 10 & 187 \\
\hline PSB 7 & 0 to 1 & 1660 \\
\hline PSB 7 & 1 to 4 & 370 \\
\hline PSB 7 & 4 to 7 & 195 \\
\hline PSB 7 & 7 to 10 & 6.97 \\
\hline PSB 26 & 0 to 1 & 262 \\
\hline PSB 26 & 1 to 4 & 792 \\
\hline PSB 26 & 4 to 7 & 10.7 \\
\hline PSB 26 & 7 to 10 & 1180 \\
\hline PSB 6 & 0 to 1 & 53.9 \\
\hline PSB 6 & 1 to 4 & 19.8 \\
\hline PSB 6 & 4 to 7 & 1.51 \\
\hline PSB 6 & 7 to 10 & 1.03 \\
\hline PSB 6A & 0 to 1 & 246 \\
\hline PSB 6A & 1 to 4 & 19.6 \\
\hline PSB 6A & 4 to 7 & 0.574 \\
\hline PSB 6A & 7 to 10 & 0.428 \\
\hline * estimated a ${ }^{137}$ Cs value based on \\
the ${ }^{137}$ Cs concentration in the $1-4 \mathrm{ft}$ \\
interval \\
\hline \multicolumn{2}{|l|}{} \\
\hline
\end{tabular}


Calculations of ${ }^{137} \mathrm{Cs}$ in seepage basin \#1

\begin{tabular}{|c|c|c|c|c|c|c|c|c|c|c|}
\hline \multirow{2}{*}{ zone } & \multirow{2}{*}{ layer } & \multirow{2}{*}{ thickness } & \multicolumn{2}{|c|}{ concentration $(\mathrm{pCi} / \mathrm{g})$} & \multirow{2}{*}{$\begin{array}{l}\text { area of zone } \\
\text { (fraction of }\end{array}$} & \multirow{2}{*}{ soil mass (g) } & \multirow{2}{*}{$\begin{array}{c}\text { average basis } \\
\text { total activity }\end{array}$} & \multirow{2}{*}{$\begin{array}{l}\text { median basis } \\
\text { total activity }\end{array}$} & \multirow{2}{*}{$\begin{array}{c}\text { upper } 90 \% \\
\text { confidence interval }\end{array}$} & \multirow{2}{*}{$\begin{array}{c}\text { lower } 90 \% \\
\text { confidence interval }\end{array}$} \\
\hline & & & average & median & & & & & & \\
\hline Area A & 1 & 1 & 1162.67 & 1570.00 & 0.23 & $2.46 \mathrm{E}+08$ & $2.86 \mathrm{E}-01$ & $3.87 \mathrm{E}-01$ & $4.70 \mathrm{E}-01$ & $1.03 \mathrm{E}-01$ \\
\hline Area A & 2 & 3 & 497.33 & 370.00 & 0.23 & $7.39 \mathrm{E}+08$ & $3.67 \mathrm{E}-01$ & $2.73 \mathrm{E}-01$ & $5.28 \mathrm{E}-01$ & $2.07 \mathrm{E}-01$ \\
\hline Area A & 3 & 3 & 8208.33 & 4630.00 & 0.23 & $7.39 \mathrm{E}+08$ & $6.06 \mathrm{E}+00$ & $3.42 \mathrm{E}+00$ & $1.33 \mathrm{E}+01$ & $0.00 \mathrm{E}+00$ \\
\hline Area A & 4 & 3 & 994.66 & 187.00 & 0.23 & $7.39 \mathrm{E}+08$ & $7.35 \mathrm{E}-01$ & $1.38 \mathrm{E}-01$ & $1.83 \mathrm{E}+00$ & $0.00 \mathrm{E}+00$ \\
\hline Area B & 1 & 1 & 563.33 & 540.00 & 0.24 & $2.57 \mathrm{E}+08$ & $1.45 \mathrm{E}-01$ & $1.39 \mathrm{E}-01$ & $2.53 \mathrm{E}-01$ & $3.60 \mathrm{E}-02$ \\
\hline Area B & 2 & 3 & 5965.33 & 3490.00 & 0.24 & $7.71 \mathrm{E}+08$ & $4.60 \mathrm{E}+00$ & $2.69 \mathrm{E}+00$ & $9.74 \mathrm{E}+00$ & $0.00 \mathrm{E}+00$ \\
\hline Area B & 3 & 3 & 42.46 & 21.20 & 0.24 & $7.71 \mathrm{E}+08$ & $3.27 \mathrm{E}-02$ & $1.63 \mathrm{E}-02$ & $7.37 \mathrm{E}-02$ & $0.00 \mathrm{E}+00$ \\
\hline Area B & 4 & 3 & 5.73 & 6.55 & 0.24 & $7.71 \mathrm{E}+08$ & $4.42 \mathrm{E}-03$ & $5.05 \mathrm{E}-03$ & $6.76 \mathrm{E}-03$ & $2.08 \mathrm{E}-03$ \\
\hline Area $\mathrm{C}$ & 1 & 1 & 400.00 & 400.00 & 0.33 & $3.53 \mathrm{E}+08$ & $1.41 \mathrm{E}-01$ & $1.41 \mathrm{E}-01$ & $3.16 \mathrm{E}-01$ & $0.00 \mathrm{E}+00$ \\
\hline Area C & 2 & 3 & 425.50 & 425.50 & 0.33 & $1.06 \mathrm{E}+09$ & $4.51 \mathrm{E}-01$ & $4.51 \mathrm{E}-01$ & $9.90 \mathrm{E}-01$ & $0.00 \mathrm{E}+00$ \\
\hline Area $\mathrm{C}$ & 3 & 3 & 1.73 & 1.73 & 0.33 & $1.06 \mathrm{E}+09$ & $1.83 \mathrm{E}-03$ & $1.83 \mathrm{E}-03$ & $2.34 \mathrm{E}-03$ & $1.33 \mathrm{E}-03$ \\
\hline Area C & 4 & 3 & 1.08 & 1.08 & 0.33 & $1.06 \mathrm{E}+09$ & $1.15 \mathrm{E}-03$ & $1.15 \mathrm{E}-03$ & $1.93 \mathrm{E}-03$ & $3.67 \mathrm{E}-04$ \\
\hline Area D & 1 & 1 & 187.30 & 246.00 & 0.20 & $2.14 \mathrm{E}+08$ & $4.01 \mathrm{E}-02$ & $5.27 \mathrm{E}-02$ & $6.36 \mathrm{E}-02$ & $1.66 \mathrm{E}-02$ \\
\hline Area D & 2 & 3 & 277.13 & 19.80 & 0.20 & $6.42 \mathrm{E}+08$ & $1.78 \mathrm{E}-01$ & $1.27 \mathrm{E}-02$ & $4.50 \mathrm{E}-01$ & $0.00 \mathrm{E}+00$ \\
\hline Area D & 3 & 3 & 4.26 & 1.51 & 0.20 & $6.42 \mathrm{E}+08$ & $2.74 \mathrm{E}-03$ & $9.70 \mathrm{E}-04$ & $6.15 \mathrm{E}-03$ & $0.00 \mathrm{E}+00$ \\
\hline Area D & 4 & 3 & 393.82 & 1.03 & 0.20 & $6.42 \mathrm{E}+08$ & $2.53 \mathrm{E}-01$ & $6.61 \mathrm{E}-04$ & $6.68 \mathrm{E}-01$ & $0.00 \mathrm{E}+00$ \\
\hline & & & & & & tal for basin = & $1.33 \mathrm{E}+01$ & $7.73 \mathrm{E}+00$ & $2.87 E+01$ & $3.66 \mathrm{E}-01$ \\
\hline
\end{tabular}

Calculations of ${ }^{137} \mathrm{Cs}$ in seepage basin \#2

\begin{tabular}{|c|c|c|c|c|c|c|c|c|c|}
\hline \multirow{2}{*}{ layer } & \multirow{2}{*}{ thickness } & \multicolumn{2}{|c|}{ concentration $(\mathrm{pCi} / \mathrm{g})$} & \multirow{2}{*}{$\begin{array}{l}\text { area of zone } \\
\text { (fraction of }\end{array}$} & \multirow{2}{*}{ soil mass (g) } & \multirow{2}{*}{$\begin{array}{l}\text { average basis } \\
\text { total activity }\end{array}$} & \multirow{2}{*}{$\begin{array}{l}\text { median basis } \\
\text { total activity }\end{array}$} & \multirow{2}{*}{$\begin{array}{c}\text { upper } 90 \% \\
\text { confidence interval }\end{array}$} & \multirow{2}{*}{$\begin{array}{c}\text { lower } 90 \% \\
\text { confidence interval }\end{array}$} \\
\hline & & average & median & & & & & & \\
\hline 1 & 1 & 419.25 & 386 & 1 & $6.42 \mathrm{E}+08$ & $2.69 \mathrm{E}-01$ & $2.48 \mathrm{E}-01$ & $4.63 \mathrm{E}-01$ & $7.55 \mathrm{E}-02$ \\
\hline 2 & 3 & 117.49 & 4.555 & 1 & $1.93 \mathrm{E}+09$ & $2.26 \mathrm{E}-01$ & $8.78 \mathrm{E}-03$ & $5.87 \mathrm{E}-01$ & $0.00 \mathrm{E}+00$ \\
\hline & & & & & Total for basin $=$ & $4.96 \mathrm{E}-01$ & $2.57 \mathrm{E}-01$ & $1.05 \mathrm{E}+00$ & $7.55 \mathrm{E}-02$ \\
\hline \multirow{3}{*}{\multicolumn{2}{|c|}{$\begin{array}{c}\text { Total Basin Area }= \\
\text { Total Depth* }= \\
\text { Bulk Density }=\end{array}$}} & 12000 & $\mathrm{ft}^{\wedge} 2$ & & & & & & \\
\hline & & 4 & $\mathrm{ft}$ & & & & & & \\
\hline & & 1.89 & $\mathrm{~g} / \mathrm{cm}^{\wedge} 3$ & & & & & & \\
\hline
\end{tabular}

$* 96 \%$ of total radioactivity within first 4 ' below surface 